\title{
INEQUITABLE CONDUCT AND WALKER PROCESS Claims AfTer THERASENSE AND THE AMERICA INVENTS ACT ${ }^{\dagger}$
}

\author{
Gideon Mark* \\ T. Leigh Anenson**

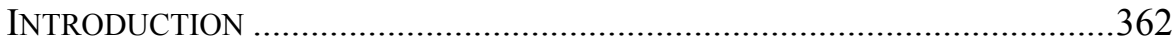 \\ I.THE ORIGIN AND DEVELOPMENT OF INEQUITABLE

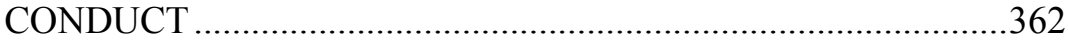 \\ A.Elements of the Inequitable Conduct Defense............................364 \\ B.Effects of the Inequitable Conduct Defense.................................369

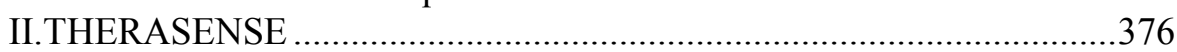

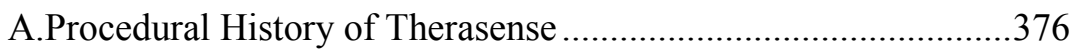

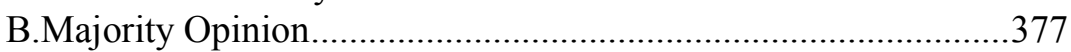

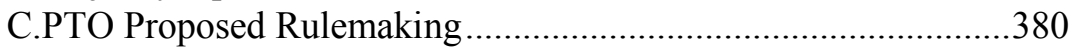 \\ D.The Negative Impact of Therasense............................................381 \\ E. Walker Process Antitrust Claims...............................................394

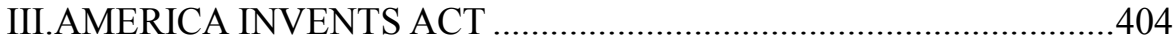

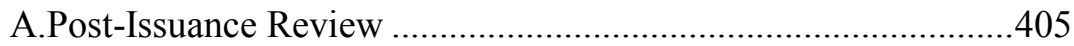

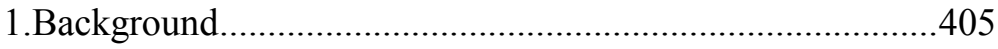

$\dagger$ A condensed version of this article appeared as a chapter in THE CHANGING FACE OF US PATENT LAW AND ITS IMPACT ON BUSINESS STRATEGY 82 (Daniel R. Cahoy \& Lynda J. Oswald eds., 2013). Portions of that chapter appear throughout this article without specific citation.

* Assistant Professor of Business Law, University of Maryland Robert H. Smith School of Business; gmark@rhsmith.umd.edu. Professor Mark holds degrees from Brandeis University, Columbia University, Harvard University, New York University, and the University of California. The authors thank Matthew Touton for his valuable research assistance. The authors also thank Dan Cahoy and Lynda Oswald for their invitation to present much of the research included herein at the May 2012 Patent Scholars Colloquium co-hosted by the University of Michigan and Penn State University.

** Associate Professor of Business Law, University of Maryland Robert H. Smith School of Business; lanenson@rhsmith.umd.edu. Senior Fellow, Business Law \& Taxation, Monash University; Of Counsel, Reminger Co., L.P.A. 
2.Post-Grant Review

3.Inter Partes Review.

4.Supplemental Examination

\section{INTRODUCTION}

This Article examines the severe constriction of the inequitable conduct defense to patent infringement accomplished in 2011 by the issuance of the Federal Circuit's decision in Therasense, Inc. v. Becton, Dickinson \& Co. (Therasense) and the enactment of the America Invents Act (AIA). ${ }^{1}$ The Article argues that Therasense and the AIA have unduly narrowed the inequitable conduct doctrine and thus undermined core functions of United States patent law. Those core functions include: (1) nurturing and rewarding innovation; (2) encouraging full and early disclosure of inventions, to promote further innovation and to permit the public to practice the inventions once the patents expire; (3) avoiding monopolies that unnecessarily stifle competition; and (4) assuring that ideas in the public domain remain there for free use by the public. ${ }^{2}$ The Article concludes that Therasense and specific features of the AIA, particularly its adoption of new post-issuance review proceedings and a new best mode amendment, will operate in tandem to sharply curtail the availability of the inequitable conduct defense and thereby impair the operation of the U.S. patent system. Simultaneously, Therasense will unduly limit the opportunity for parties to assert Walker Process antitrust claims. In short, the cure has been worse than the plague on the patent system that critics have commonly attributed to the inequitable conduct doctrine.

\section{THE ORIGIN AND DEVELOPMENT OF INEQUITABLE CONDUCT}

Inequitable conduct in procuring a patent before the U.S. Patent and Trademark Office (PTO) is a judicially created defense to patent infringement that has been described as the "key gatekeeper policing the

1. Pub. L. No. 112-29, 125 Stat. 284 (2011) (codified in scattered sections of 35 U.S.C.).

2. See, e.g., Pfaff v. Wells Elecs., Inc., 525 U.S. 55, 63 (1998) (observing that U.S. patent system seeks to balance promotion of innovation with avoidance of monopolies that unreasonably suppress competition); Aronson v. Quick Point Pencil Co., 440 U.S. 257, 262 (1979) (identifying primary purposes of the federal patent system). 
[U.S.] patent system's integrity." ${ }^{3}$ No federal statute expressly provides for the defense, although 35 U.S.C. $\S 282$ does mandate the availability of a defense of unenforceability in any action involving the validity or infringement of a patent. ${ }^{4}$ The 1952 Patent Act (the last major revision of U.S. patent law prior to the AIA) ${ }^{5}$ and its legislative history are both silent concerning the grounds and standard of proof for an inequitable conduct defense. $^{6}$

Instead, the non-statutory doctrine evolved from the equitable defense of unclean hands, ${ }^{7}$ which is based on the equitable maxim that "he who comes into equity must come with clean hands." ${ }^{8}$ The defense of unclean hands was applied in a trilogy of pre-1950 Supreme Court patent cases Precision Instrument Mfg. Co. v. Auto. Maintenance Machinery Co.

3. See Katherine E. White, "There's a Hole in the Bucket:" The Effective Elimination of the Inequitable Conduct Doctrine, 11 J. Marshall Rev. Intell. Prop. L. 716, 717 (2012). Accord Tun-Jen Chiang, The Upside-Down Inequitable Conduct Defense, $107 \mathrm{Nw}$. U. L. REV. 1243, 1295 (2013) (describing the inequitable conduct defense as "the primary doctrinal safeguard against patent dishonesty").

4. 35 U.S.C. § 282(b) (2000). Cf. John M. Golden, Patent Law's Falstaff: Inequitable Conduct, the Federal Circuit, and Therasense, 7 WASH. J.L., TECH. \& ARTS 353, 356 (2012) ("Arguably, the defense is implicit in statutory law."); David Hricik \& Seth Trimble, Congratulations on Your Hallucinations: Why the PTO's 1992 Amendment to $\& 1.56$ is Irrelevant to Inequitable Conduct, 38 AIPLA Q.J. 1, 4 (2010) ("[I]n 1952, Congress codified the defense of inequitable conduct at 35 U.S.C. § 282.").

5. David S. Abrams \& R. Polk Wagner, Poisoning the Next Apple? The America Invents Act and Individual Inventors, 65 STAN. L. REV. 517, 519 n.6 (2013) (describing the development of the 1952 Patent Act).

6. B.D. Daniel, Heightened Standards of Proof in Patent Infringement Litigation: A Critique, 36 AIPLA Q.J. 369, 382 (2008) ("The 1952 Act and its legislative history are both silent on the issue of the grounds for an 'inequitable conduct' defense, much less a heightened standard of proof for such a defense.").

7. See Gen. Electro Musical Corp. v. Samick Music Corp., 19 F.3d 1405, 1408 (Fed. Cir. 1994) ("The concept of inequitable conduct in patent procurement derives from the equitable doctrine of unclean hands: that a person who obtains a patent by intentionally misleading the PTO can not [sic] enforce the patent."') (quoting Demarco Corp. v. F. Von Langsdorff Licensing Ltd., 851 F.2d 1387, 1394 (Fed. Cir. 1988)); Shieldmark, Inc. v. Creative Safety Supply, LLC, No. 1:12CV221, 2013 WL 123567, at *3 (S.D. Ohio Jan. 9, 2013) (same).

8. See, e.g., Apotex, Inc. v. UCB, Inc., No. 12-60706-CIV, 2013 WL 4811231, at *21 (S.D. Fla. Sept. 9, 2013); see also Nordock Inc. v. Sys., Inc., 927 F. Supp. 2d 577, 607 (E.D. Wis. 2013) (quoting Precision Instrument Mfg. Co. v. Auto Maint. Mach. Co., 324 U.S. 806,814 (1945)) ("The defense of unclean hands is based on the equitable maxim that 'he who comes into equity must come with clean hands"'). To prove the defense of unclean hands in patent cases a defendant must show that the patentee "conducted itself as to shock the moral sensibilities of the judge, or stated otherwise, that the patentee's conduct was offensive to the dictates of natural justice." Multimedia Patent Trust v. Apple Inc., No. 10CV-2618-H (KSC), 2012 WL 6863471, at*22 (S.D. Cal. Nov. 9, 2012). Accord Honeywell Int'l, Inc. v. Universal Avionics Sys. Corp., 398 F. Supp. 2d 305, 310 (D. Del. 2004) (outlining the same legal standard for proving unclean hands). 
(Precision), ${ }^{9}$ Hazel-Atlas Glass Co. v. Hartford Empire Co.,${ }^{10}$ and Keystone Driller Co. v. General Excavator Co. ${ }^{11}$ - involving clear-cut scenarios of perjury, the manufacture of false evidence, and the suppression of evidence. The doctrine of inequitable conduct was first clearly articulated by the Supreme Court in Precision, which held that courts could dismiss patent infringement suits based on inequitable conduct committed during the patent's prosecution. ${ }^{12}$

The Supreme Court in Precision and the Federal Circuit in Therasense confirmed that the inequitable conduct doctrine serves multiple important policy objectives, and scholars are in accord. These objectives include protecting the integrity of the patent system by ensuring applicant candor, encouraging patent applicants to internalize costs of the patent system, avoiding patent monopolies that stem from inequitable conduct, and punishing patentees who behave inequitably toward the public during the patent acquisition process. ${ }^{13}$

\section{A. Elements of the Inequitable Conduct Defense}

Traditional inequitable conduct analysis in patent cases involves two elements. The accused patent infringer must show by clear and convincing evidence that: (1) an individual associated with the filing and prosecution of a patent application made an affirmative misrepresentation of a material fact, failed to disclose material information, or submitted false material information to the PTO; and (2) did so with the intent to deceive the PTO. ${ }^{14}$ If both requirements are met, the trial judge has the discretion to declare the subject patent unenforceable. An unenforceable patent is effectively useless to the patentee. As courts have recognized, "because only the

9. 324 U.S. 806 (1945) (finding unclean hands where patentee suppressed evidence of perjury before the PTO and attempted to enforce perjury-tainted patent).

10. 322 U.S. 238 (1944) (finding unclean hands where patentee manufactured false article in support of its patent application and later suppressed the article), overruled on other grounds by Standard Oil Co. v. United States, 429 U.S. 17 (1976).

11. 290 U.S. 244 (1933) (finding unclean hands where patentee submitted false affidavit to PTO to overcome a prior use).

12. 324 U.S. at 819 (concluding that "inequitable conduct impregnated Automotive's entire cause of action and justified dismissal").

13. See id. at 816 (noting that the public maintains "a paramount interest in seeing that patent monopolies spring from backgrounds free from fraud or other inequitable conduct"); Therasense, Inc. v. Becton, Dickinson \& Co., 649 F.3d 1276, 1292 (Fed. Cir. 2011) (en banc) (noting that "[a]s an equitable doctrine, inequitable conduct hinges on basic fairness"); Lee Petherbridge, Jason Rantanen \& Ali Mojibi, The Federal Circuit and Inequitable Conduct: An Empirical Assessment, 84 S. CAL. L. REV. 1293, 1295 (2011) (discussing the punishment function of inequitable conduct doctrine).

14. Astrazeneca Pharms. LP v. Teva Pharms. USA, Inc., 583 F.3d 766, 770 (Fed. Cir. 2009) (citing Kingsdown Med. Consultants, Ltd. v. Hollister, Inc., 863 F.2d 867, 872 (Fed. Cir. 1988)). 
patent holder possesses the right to enforce a patent against infringement, ${ }^{15}$ the inequitable conduct doctrine operates solely against the patent holder." 16

The defense of inequitable conduct is wholly equitable in character and therefore a matter for the court to decide. ${ }^{17}$ The courts are "not bound by the definition of materiality in PTO rules."18 Nevertheless, prior to Therasense, the Federal Circuit commonly followed PTO Rule $56^{19}$ which was originally adopted as part of the Rules of Practice in 1949 and then substantially reformulated in 1977 and 1992 — in determining whether information was material. ${ }^{20}$ Rule 56 imposes on each individual associated with the filing and prosecution of a patent application a duty of candor to the PTO, including a duty to disclose to the PTO all information known to that individual to be material to patentability. ${ }^{21}$

While courts commonly followed Rule 56, five different standards of materiality emerged ${ }^{22}$ and the judiciary vacillated on which standard to use. $^{23}$ As noted in Therasense, the proliferation of materiality standards produced ambiguity and contradiction in the development of the doctrine of inequitable conduct. ${ }^{24}$ But in recent years, the choice of standards often narrowed to those reflected in the 1977 and 1992 amendments. The

15. 35 U.S.C. $\S 281(2006)$

16. Shieldmark, Inc. v. Creative Safety Supply, LLC, No. 1:12CV221, 2013 WL 123567, at*3 (S.D. Ohio Jan. 9, 2013).

17. PerSeptive Biosystems, Inc. v. Pharmacia Biotech, Inc., 225 F.3d 1315, 1318 (Fed. Cir. 2000) ("The defense of inequitable conduct is entirely equitable in nature, and thus not an issue for a jury to decide."); ABT Sys., LLC v. Emerson Elec. Co., No. 4:11CV00374 AGF, 2013 WL 425399, at*1 (E.D. Mo. Feb. 4, 2013) (citing PerSeptive Biosystems, Inc. v. Pharmacia Biotech, Inc., 225 F.3d 1315, 1318 (Fed. Cir. 2000)).

18. Therasense, 649 F.3d at 1294; CoStar Realty Information, Inc. v. CIVIX-DDI, LLC, Nos. 12 C 4968, 12 C 7091, 12 C 8632, 2013 WL 2151548, at *5 (N.D. Ill. May 15, 2013) (citing to Therasense, 649 F.3d at 1294).

19. 37 C.F.R. $\S 1.56$ (2013).

20. See Avid Ident. Sys., Inc. v. Crystal Imp. Corp., 603 F.3d 967, 972 (Fed. Cir. 2010) ("In evaluating materiality, this court typically refers to the definition provided in 37 C.F.R. $\S 1.56$, by which the PTO promulgated the duty of disclosure.”).

21. 37 C.F.R. $\S 1.56(a)$ (2013). This duty applies to (1) each named inventor, (2) each attorney or agent who prepares or prosecutes the application, and (3) to anyone who is substantively involved in the patent prosecution. 37 C.F.R. § 1.56(c) (2013); Avid Ident. Sys., Inc. v. Crystal Import Corp., 603 F.3d 967, 973 (Fed. Cir. 2010). A person is substantively involved if the involvement relates to the content of the application or decisions related thereto and is not wholly administrative or secretarial in nature. Id. at 974.

22. See Thomas F. Cotter, An Economic Analysis of Patent Law's Inequitable Conduct Doctrine, 53 ARIZ. L. REV. 735, 744 (2011) (describing the five different standards for defining materiality); White, supra note 3, at 724-25.

23. See generally Hricik \& Trimble, supra note 4, at 3 (providing an overview of the development of different standards for determining materiality)

24. Therasense, Inc. v. Becton, Dickinson \& Co., 649 F.3d 1276, 1294 (Fed. Cir. 2011) (en banc). 
remaining three standards were reflected in case law developed before the Federal Circuit, the near-exclusive appellate court for patent cases, ${ }^{25}$ was formed in 1982, primarily to instill uniformity in patent law and permit more expert review of patent appeals by a specialized court. ${ }^{26}$

Rule 56 as originally adopted prohibited fraud but said nothing about inequitable conduct. The original version, adopted in 1949 (several years after the Supreme Court decided Precision), stated that "any application fraudulently filed or in connection with which any fraud is practiced or attempted on the Patent Office, may be stricken from the files." ${ }^{27}$ The definition of fraud in this context was unclear. ${ }^{28}$

The 1977 amendment transformed Rule 56 from a provision enabling the PTO to strike applications for fraud to one that formally established a duty of candor and good faith by patent applicants and their attorneys to disclose information they were aware of that was material to the examination of the application. The 1977 amendment adopted a "reasonable examiner" standard by defining information as "material" if there was a substantial likelihood that a reasonable examiner would consider it important in deciding whether to allow the application to issue as a patent. ${ }^{29}$ In making this change the PTO stated that the amendment "codifie[d] the existing Office policy on fraud and inequitable conduct, which is believed consistent with the prevailing case law in the federal courts." ${ }^{30}$ In the ensuing years the Federal Circuit regularly referred to this standard as the one to use in cases raising claims of inequitable conduct. ${ }^{31}$ Pursuant to the 1977 amendment, a false statement or nondisclosure could be material for purposes of an inequitable conduct determination even if the invention in question would otherwise be patentable. ${ }^{32}$

25. Paul R. Gugliuzza, Rethinking Federal Circuit Jurisdiction, 100 GEO. L.J. 1437, 1453 (2012).

26. David Olson \& Stefania Fusco, Rules Versus Standards: Competing Notions of Inconsistency Robustness in Patent Law, 64 ALA. L. REV. 647, 681 (2013) (inferring from legislative history that Congress hoped for a consolidation of all patent appeals in one circuit court in order to promote standardization and expertise); James R. Barney, A Guide to Appealing Patent Cases to the US Court of Appeals for the Federal Circuit, 2013 WL 574526, at *11 (Aspatore, 2013) (noting that the Federal Circuit was created to realize uniformity in patent law). But cf. Paul R. Gugliuzza, The Federal Circuit as a Federal Court, 54 WM. \& MARY L. REv. 1791, 1802 (2013) ("It is not clear whether the Federal Circuit has brought uniformity, quality, or efficiency to patent law.").

27. 37 C.F.R. $\S 1.56$ (1949).

28. Dashiell Milliman-Jarvis, The State of Ethical Duties After Therasense, 25 Geo. J. Legal Ethics 695, 699 (2012) (observing that the definition of "fraud" in this context was largely unknown).

29. 37 C.F.R. $\S 1.56(a)$ (1977).

30. Duty of Disclosure, 42 Fed. Reg. 5588, 5589 (Jan. 28, 1977).

31. Dayco Prods., Inc. v. Total Containment, Inc., 329 F.3d 1358, 1365 (Fed. Cir. 2003) (applying the "reasonable examiner" standard to determine inequitable conduct).

32. Digital Control, Inc. v. Charles Mach. Works, 437 F.3d 1309, 1318 (Fed. Cir. 
The PTO amended Rule 56 in 1992 in response to criticism that the reasonable examiner standard was vague and unrelated to any concept applied in other areas of patent law. ${ }^{33}$ The 1992 amendment continued to impose a duty to disclose material information, but it provided a more refined definition of materiality. The amended Rule 56, which remained in effect at least until 2014, imposes a duty on individuals ${ }^{34}$ associated with the filing and prosecution of an application to disclose to the PTO all information known to be material to patentability as defined in the rule. Information is material when

it is not cumulative to information already of record or made of record in the application and (1) [i]t establishes, by itself or in combination with other information, a prima facie case of unpatentability of a claim; or (2) it refutes, or is inconsistent with, a position the applicant takes in: (i) [o]pposing an argument of unpatentability relied upon by the [PTO], or (ii) [a]sserting an argument of patentability. ${ }^{35}$

When it adopted the 1992 amendment, the PTO considered and rejected the adoption of a but-for test of materiality. It did so because it concluded that use of such a narrow standard would not enable the PTO to obtain the information it required to properly evaluate patentability. ${ }^{36}$ Rule 56's materiality standard, as adopted in 1977 and refined in 1992, was also consistent with the materiality standard applied in a range of analogous contexts. As the Therasense dissent noted, ${ }^{37}$ the use of a but-for standard has been rejected in the context of, inter alia, fraudulent registration of copyrights and trademarks, ${ }^{38}$ proxy solicitations regulated under section

2006) (noting that a misstatement or omission can be material notwithstanding a determination that the invention is unpatentable).

33. Donald S. Chisum, Best Mode Concealment and Inequitable Conduct in Patent Procurement: A Nutshell, a Review of Recent Federal Circuit Cases and a Plea for Modest Reform, 13 Santa Clara Computer \& High TeCH. L.J. 277, 296 (1997) (detailing what the changed reasonable examiner standard entails).

34. Only individuals owe a duty of candor to the PTO under Rule 56. Corporations do not. Avid Ident. Sys., Inc. v. Crystal Imp. Corp., 603 F.3d 967, 974 n.1 (Fed. Cir. 2010) (explaining that only a breach of the duty of candor to the PTO by an individual may give rise to a finding of inequitable conduct); see also Aevoe Corp. v. AE Tech. Co., No. 2:12cv-00053-GMN-NJK, 2013 WL 876036, at *6 (D. Nev. Mar. 7, 2013) (discussing which specific party failed to disclose material prior art and holding that defendants' failure to name a specific individual in a general counterclaim alleging that "Applicants ... did not comply with their duty of disclosure" should result in dismissal of the claim).

35. 37 C.F.R. $\S 1.56(b)(2012)$.

36. Therasense, Inc. v. Becton, Dickinson \& Co., 649 F.3d 1276, 1310-14 (Fed. Cir. 2011) (Bryson, J., dissenting) (explaining why Rule 56 clearly extends beyond the but-for standard).

37. Id. at 1315-16 (Bryson, J., dissenting) (listing situations where the but-for test was rejected).

38. Eckes v. Card Prices Update, 736 F.2d 859, 861-62 (2d Cir. 1984) (“Only the 
14(a) of the Securities Exchange Act of $1934,{ }^{39}$ criminal prosecutions under the federal mail and fraud statutes, ${ }^{40}$ and the element of materiality in common law fraud. ${ }^{41}$

The amended Rule 56, consistent with the 1949 and 1977 versions, continued to omit use of the term "inequitable conduct." The PTO has justified this continuing omission on the ground that inequitable conduct encompasses too expansive a range of conduct to be subject to mandatory striking. ${ }^{42}$ The 1992 version of Rule 56 was never fully embraced by federal courts, ${ }^{43}$ and until Therasense was decided, the Federal Circuit continued to cite the reasonable examiner standard for materiality that was set forth in the 1977 version. $^{44}$ Indeed, some post-Therasense federal

'knowing failure to advise the Copyright Office of facts which might have occasioned a rejection of the application constitute[s] reason for holding the registration invalid and thus incapable of supporting an infringement action ... or denying enforcement on the ground of unclean hands...."') (internal quotation omitted); see also generally 2 MELVILLE B. NiMMER \& DAVID NIMMER, NiMMER ON COPYRIGHT § 7.20[B][1] at 7-212, 4(1) \& n.21 (rev. ed. 2010).

39. TSC Indus., Inc. v. Northway, Inc., 426 U.S. 438, 449 (1976) (rejecting a standard that would require a showing that a voter would have changed his vote but for a misstatement or omission in proxy materials and instead adopting a standard requiring the injured party to show that the misstatement or omission was material, i.e., that "there is a substantial likelihood that a reasonable shareholder would consider it important in deciding how to vote").

40. 18 U.S.C. $\S \S 1341,1343$ (2006). As the dissent noted, when a charge of mail or wire fraud is based on the nondisclosure of material information in violation of a duty to disclose, proof of materiality does not require a showing of actual reliance on the part of the victim. All that is required is proof that the nondisclosure or concealment was capable of influencing the intended victim. 649 F.3d at 1315 (Bryson, J., dissenting) (citing Neder v. United States, 527 U.S. 1, 16 (1999)).

41. Restatement (SECOND) OF TORTS $§ 538$ (1977) (stating that not all fraudulent misrepresentations are material).

42. Sean M. O'Connor, Defusing the "Atomic Bomb" of Patent Litigation: Avoiding and Defending Against Allegations of Inequitable Conduct After McKesson et al., $9 \mathrm{~J}$. Marshall ReV. InTEll. Prop. L. 330, 349 (2010).

43. See George G. Gordon \& Stephen A. Stack, Aligning Antitrust and Patent Law: Side Effects from the Federal Circuit's Cure for the Inequitable Conduct "Plague" in Therasense, 26 ANTITRUST 88, 89 (2011) (observing that before Therasense, the Federal Circuit's interpretation of the elements of inequitable conduct contrasted with the interpretation by the PTO under Rule 56). In Digital Control Inc. v. Charles Machine Works, 437 F.3d 1309, 1316 (Fed. Cir. 2006), the Federal Circuit reasoned that the 1992 version of Rule 56 was "not intended to replace or supplant the 'reasonable examiner' standard."

44. See, e.g., Golden Hour Data Sys., Inc. v. emsCharts Inc., 614 F.3d 1367, 1373-74 (Fed. Cir. 2010) (determining the materiality of information by whether the reasonable examiner considers it important for issuing the patent); Avid Ident. Sys., Inc. v. Crystal Imp. Corp., 603 F.3d 967, 972 (Fed. Cir. 2010) ("Information is material where a reasonable examiner would find it important to a determination of patentability."); Astrazeneca Pharm. LP v. Teva Pharm. USA Inc., 583 F.3d 766, 773 (Fed. Cir. 2009) (citing the reasonable examiner standard as the most often-employed standard for establishing materiality). 
courts continued to cite the reasonable examiner standard. ${ }^{45}$

The other element of inequitable conduct is intent. In Precision, the Supreme Court's only major discussion of inequitable conduct, the Court failed to delineate the requisite level of intent, although it did refer to, inter alia, willful conduct. ${ }^{46}$ The requisite level of intent has varied considerably since Precision, ranging on the spectrum from negligence to gross negligence to recklessness to specific intent. ${ }^{47}$ Because direct evidence of intent to deceive is rare, ${ }^{48}$ a finding of intent pre-Therasense was often based on the totality of the circumstances, including circumstantial evidence. $^{49}$

\section{B. Effects of the Inequitable Conduct Defense}

The inequitable conduct defense has been described as a "critical part of the complicated system of checks and balances that constitutes U.S. patent law. ${ }^{, 50}$ Specifically, the defense can help correct for: (1) the PTO's limited ability to carefully review all material potentially relevant to patentability; (2) the strong incentive for deception provided by an issued patent's presumption of validity in litigation; and (3) the absence of procedures to challenge the validity of patent rights that are as robust as those found in Japan and the European Union. ${ }^{51}$ The defense is especially

45. See, e.g., Seiko Epson Corp. v. E-Babylon, Inc., No. 3:07-CV-896-BR, 2011 WL 5554447 , at $* 2$ (D. Or. Nov. 15, 2011) (holding that a material reference is one that a reasonable examiner would consider important in considering the patent application).

46. Precision Instrument Mfg. Co. v. Auto. Maint. Mach. Co., 324 U.S. 806, 814-15 (1945) (explaining what is required of the nature of misconduct to be punished as a crime or to justify legal proceedings).

47. See generally Robert J. Goldman, Evolution of the Inequitable Conduct Defense in Patent Litigation, 7 HARV. J.L. \& TECH. 37 (1993) (tracing the development of inequitable conduct and the requisite level of intent); Thomas L. Irving, Lauren L. Stevens, Scott M.K. Lee \& Alexis N. Simpson, The Evolution of Intent: A Review of Patent Law Cases Invoking the Doctrine of Inequitable Conduct from Precision to Exergen, 35 U. DAYTON L. REv. 303 (2010) (addressing the unpredictability of inequitable conduct in patent law).

48. Gen. Elec. Co. v. Mitsubishi Heavy Indus. Ltd., No. 3:10-CV-276-F, 2013 WL 2338345, at *36 (N.D. Tex. May 28, 2013).

49. See Paragon Podiatry Lab., Inc. v. KLM Labs., Inc., 984 F.2d 1182, 1189-90 (Fed. Cir. 1993) (noting that in inequitable conduct cases, intent "must generally be inferred from the facts and circumstances surrounding the applicant's overall conduct"); Dorothy Auth \& Jason M. Rockman, Federal Circuit Considers 'Inequitable Conduct' En Banc, N.Y.L.J., Aug. 16, 2010, at 1 ("Because direct evidence of an intent to deceive is rare, 'intent to deceive' is often based on the totality of the circumstances, including circumstantial evidence.").

50. Golden, supra note 4, at 359.

51. Id. at 359-60. Accord Jason Rantanen \& Lee Petherbridge, Toward a System of Invention Registration: The Leahy-Smith America Invents Act, $110 \mathrm{MICH}$. L. REV. FIRST

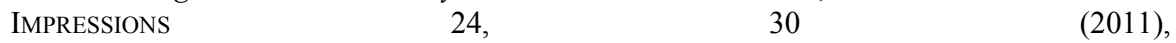
http://www.michiganlawreview.org/assets/fi/110/rantanenpetherbridge.pdf (describing the 
important because patent prosecution in the U.S. is generally ex parte. ${ }^{52}$

But the defense has an army of critics. One scholar has concluded that the inequitable conduct doctrine "attracts more passionate loathing, and stronger criticism, than any other doctrine in patent law." 53 The inequitable conduct defense has frequently been referred to as the "atomic bomb" of patent law $^{54}$ because its success renders the entire patent permanently unenforceable, even if the undisclosed information was material to only a single claim, ${ }^{55}$ and may also render related patents unenforceable. ${ }^{56}$ Inequitable conduct may also generate claims under the antitrust and securities laws, ${ }^{57}$ taking the form of counterclaims or ensuing cases, such as antitrust class actions brought by private parties. ${ }^{58}$ The defense, insofar as it focuses on the moral turpitude of the patentee, can have negative reputational consequences for the prosecuting attorney and thereby may deter settlements. ${ }^{59}$ In other cases, assertion of the defense can multiply the cost of litigation, ${ }^{60}$ particularly by expanding discovery, and thereby have a

inequitable conduct defense as "[t]he clearest tool of pre-[AIA] patent law to discourage" nondisclosure of relevant information to the PTO).

52. Brett Ira Johnson, The Inequitable Conduct Defense in Patent Litigation: Where We Are, Where We Have Been, and Where We Should Go from Here, 28 SAnTA ClarA COMPUTER \& High TECH. L.J. 197, 234 (2012) (describing patent prosecutions as ex parte proceedings).

53. Chiang, supra note 3, at 1244.

54. See, e.g., Therasense, Inc. v. Becton, Dickinson \& Co., 649 F.3d 1276, 1288 (Fed. Cir. 2011) (en banc) (quoting Aventis Pharma S.A. v. Amphastar Pharm., Inc., 525 F.3d 1334, 1349 (Fed. Cir. 2008)) (Rader, J., dissenting).

55. Kingsdown Med. Consultants, Ltd. v. Hollister, Inc., 863 F.2d 867, 877 (Fed. Cir. 1988) (en banc) ("When a court has finally determined that inequitable conduct occurred in relation to one or more claims during prosecution of the patent application, the entire patent is rendered unenforceable.").

56. See Therasense, 649 F.3d at 1288 ("[T] can spread from a single patent to render unenforceable other related patents and applications in the same technology family."); Fox Indus., Inc. v. Structural Pres. Sys., Inc., 922 F.2d 801, 803-04 (Fed. Cir. 1990) (stating that inequitable conduct "may render unenforceable all claims which eventually issue from the same or a related application").

57. Lawrence T. Kass \& Nathaniel T. Browand, 'Therasense': Vaccine for a Plague, NAT'L L.J., June 6, 2011, at 38 (discussing the requisite proof to render a patent unenforceable for inequitable conduct).

58. Gordon \& Stack, supra note 43, at 91 (discussing collateral effects of inequitable conduct defenses in patent cases).

59. Therasense, 649 F.3d at 1288; Ian G. McFarland, Comment, In the Wake of Therasense \& Nisus Corp., How Can Patent Attorneys Defend Themselves Against Allegations of Inequitable Conduct?, 78 TENN. L. REV. 487, 499 (2011) (observing that patent attorneys who are the subject of inequitable conduct findings confront both the threat of formal discipline from the PTO and public ridicule).

60. See Christopher A. Cotropia, Modernizing Patent Law's Inequitable Conduct Doctrine, 24 BERKELEY TECH. L.J. 723, 740 (2009) (noting that "litigation of inequitable conduct claims is particularly costly"). 
coercive effect on settlements. ${ }^{61}$

The draconian nature of the defense, in combination with its preTherasense low threshold of proof, makes it appealing to accused patent infringers. One study, prepared by a committee of the American Intellectual Property Law Association and cited by Therasense, ${ }^{62}$ estimated that eighty percent of patent infringement suits contain an allegation of inequitable conduct. ${ }^{63}$ But this study contained no data or other evidence to support its estimate, ${ }^{64}$ and other accounts of the frequency with which the defense is asserted are considerably lower - ranging from less than twenty percent $^{65}$ to approximately twenty-five percent ${ }^{66}$ to sixteen to thirty-five percent $^{67}$ to forty percent. ${ }^{68}$ Moreover, appeals involving inequitable

61. In a survey by the American Bar Association, 69.4\% of approximately 3,300 responding attorneys agreed or strongly agreed that discovery is commonly used as a tool to force settlement in civil litigation. See Am. Bar Ass'n Section of Litig., Member Survey on Civil Practice: Full Report 69 (Dec. 11, 2009), http://www.abanet.org/litigation/survey/docs/report-aba-report.pdf (presenting empirical evidence on the beliefs of lawyers on the current system of civil litigation). In a separate survey, $71 \%$ of approximately 1,400 responding Fellows of the American College of Trial Lawyers agreed that discovery is used as a tool to force settlement. Am. College of Trial Lawyers \& Inst. for the Advancement of the Am. Legal Sys., Final Report on the Joint Project of the American College of Trial Lawyers Task Force on Discovery and the Institute for the Advancement of the American Legal System 9 (rev. ed. Apr. 15, 2009), $\mathrm{http}: / / \mathrm{www}$. actl.com/AM/Template.cfm?Section=Home\&template=/CM/ContentDisplay.cf $\mathrm{m} \&$ ContentID $=4008$.

62. Therasense, 649 F.3d at 1288.

63. Committee Position Paper: The Doctrine of Inequitable Conduct and the Duty of Candor in Patent Procurement: Its Current Adverse Impact on the Operation of the United States Patent System, 16 AIPLA Q.J. 74 (1988) (position paper on inequitable conduct and duty of candor).

64. Jason Rantanen, Recalibrating Our Empirical Understanding of Inequitable Conduct, 3 IP THEORY 98, 99 (2013), available at http://www.repository.law.indiana.edu/ipt/vol3/iss2/3/ (commenting on the absence of empirical evidence on rate of inequitable conduct pleadings).

65. Benjamin Brown, Comment, Inequitable Conduct: A Standard in Motion, 19 Fordham InTELl. Prop., Media \& ENT. L.J. 593, 608 (2009) (providing statistical analysis and analyzing possible consequences of reforming the defense through legislation).

66. Cotropia, supra note 60 , at 739 (providing a comprehensive, theoretical analysis on the inequitable conduct doctrine).

67. Kevin Mack, Note, Reforming Inequitable Conduct to Improve Patent Quality: Cleansing Unclean Hands, 21 BerKeley TECH. L.J. 147, 155-56 \& tbl.1 (2006) (noting that the inequitable conduct defense is adjudicated in $16-35 \%$ of all patent infringement cases that proceed to trial).

68. Christian E. Mammen, Controlling the "Plague": Reforming the Doctrine of Inequitable Conduct, 24 BERKELEY TECH. L.J. 1329, 1358-60 (2009) (noting that between 2000 and 2008, inequitable conduct pleadings at the district court level increased from four to forty percent). This study, representing perhaps the sole empirical data supporting the claim that there has been a dramatic increase in pleadings of inequitable conduct, has been criticized. See, e.g., Rantanen, supra note 64, at 100, 103-05 (citing two significant limitations of Mammen's research). 
conduct are infrequent. One survey found that the annual number of cases appealed on inequitable conduct rose from thirteen to thirty between 2004 and 2007, and then declined to twenty-six in $2008 .{ }^{69}$ Inequitable conduct is rarely a successful defense, ${ }^{70}$ but the common perception that the doctrine is asserted to excess in patent litigation is "empirically unverified.",

Patent applicants often attempt to negate the defense by providing the PTO with voluminous prior $\operatorname{art}^{72}$ references-many of which are inconsequential or unavailing ${ }^{73}$ - and concurrent patent applications for the same technology in other countries. ${ }^{74}$ This purported deluge may have

69. See The Honorable Randall R. Rader, Always at the Margin: Inequitable Conduct in Flux, 59 AM. U. L. REV. 777, 779 (2010) (presenting data on the number of cases appealed on inequitable conduct). The number of cases appealed on inequitable conduct has not kept pace with the number of new patent lawsuits, which has continued to rise in recent years. For example, the total number of new patent lawsuits jumped twenty-two percent in 2011, totaling more than four thousand new cases. Robert Harkins, How the Leahy-Smith America Invents Act (AIA) is Changing Patent Protection and Litigation, Aspatore, 2013 WL 571334, at *1 (Jan. 2013) (detailing how the AIA might cause companies to pursue different strategies in pursuing patents and engaging in patent litigation).

70. See Petherbridge, Rantanen \& Mojibi, supra note 13, at 1340 (reporting that the Federal Circuit reached an ultimate conclusion that inequitable conduct was committed approximately 2.5 times a year during the period 1983-2010); Mammen, supra note 68, at 1358-60 (concluding that during the period 1983-2008 an inequitable conduct defense succeeded on appeal to the Federal Circuit no more than five times a year); LEX MACHINA, Inequitable Conduct Defense in Patent Litigation: 2005-2010 (Jan. 5, 2011), https://lexmachina.com/files/Inequitable\%20Conduct\%20Study.pdf (reporting 41 instances of inequitable conduct findings by federal courts in 13,786 total patent infringement cases during the period January 2005-May 2010); Steve Carlson, Changes in the Law of Inequitable Conduct: New Pleading and Proof Standards 5 (May 10, 2012), available at http://www.fr.com/files/Uploads/Documents/6\%20-\%20Changes\%20in\%20the\%20Law $\% 20$ of $\% 20$ Inequitable $\% 20$ Conduct $\% 20-\% 20$ Carlson.pdf (noting that inequitable conduct is "[p]led routinely, tried frequently, and occasionally won"). In the vast majority of cases where the defense succeeds, the patent is also invalidated. Melissa Feeney Wasserman, Limiting the Inequitable Conduct Defense, 13 VA. J.L. \& TECH. 1, 23 (2008).

71. Lee Petherbridge, Jason Rantanen \& R. Polk Wagner, Unenforceability 26 (Feb. 21, 2013), Univ. of Penn. Law School, Public Law Research Paper No. 12-28; Univ. of Penn. Inst. for Law \& Econ. Research Paper No. 12-15; Univ. of Iowa Legal Studies Research Paper No. 12-10; Loyola-LA Legal Studies Paper No. 2012-28; available at http://papers.ssrn.com/sol3/papers.cfm?abstract_id=2167417 (evaluating the impact of the inequitable conduct doctrine).

72. "Prior art" refers to preexisting knowledge and technology already available to the public. See 35 U.S.C. § 102(a) (2006) (defining the documents and activities that can function as prior art); Kimberley-Clark Corp. v. Johnson \& Johnson, 745 F.2d 1437, 1453 (Fed. Cir. 1984) (discussing the competing views of the definition of prior art and concluding that the hypothetical person standard was correct).

73. Therasense, Inc. v. Becton, Dickinson \& Co., 649 F.3d 1276, 1289 (Fed. Cir. 2011) (en banc); Robert C. Scheinfeld \& Parker H. Bagley, Inequitable Conductors: All Aboard the 'Therasense' Train, N.Y.L.J., July 27, 2011, at 3.

74. Sheri Qualters, 'Therasense' a Strong Candidate for High Court Review, Patent Lawyers Say; Decision Raising the Bar for Inequitable Conduct Defense Departs from Position of PTO, DOJ, NAT'L L.J., May 26, 2011. Some portion of this deluge may be 
contributed to the PTO's backlog of pending patent applications. Approximately 500,000 patent applications are filed every year with the PTO, ${ }^{75}$ and in September 2012 approximately 608,000 applications were awaiting their first action. ${ }^{76}$ This backlog shows few signs of abating. The average pendency of U.S. patent applications exceeded three years each year during the period from 2009 to $2013 .^{77}$

Notwithstanding the foregoing, the oft-criticized deluge of prior art references is suspect for multiple reasons. First, there is remarkably little empirical evidence supporting the rote argument—highly persuasive to the Therasense majority ${ }^{78}$ - that a deluge has occurred. ${ }^{79}$ What evidence does exist tends to rebut the point by demonstrating that a small sliver of patents accounts for the bulk of voluminous prior art references. In 2012, the average patent cited forty-three references and only eight percent of patents cited more than one hundred references. ${ }^{80}$ The median submission was a mere eight references ${ }^{81}$ and more than two-thirds of the seven million prior

attributable to efforts by patent applicants to "bury" examiners with hundreds of references so as to distract them from highly relevant references. Such efforts, even if they do take place, probably do not constitute inequitable conduct. See, e.g., Seaboard Int'l, Inc. v. Cameron Int'l Corp., No. 1:13-CV-00281-MLH-SKO, 2013 WL 3936889, at *6 (E.D. Cal. July 30, 2013) (agreeing with plaintiff's argument and several federal cases that concealing material information in extensive extraneous citations to the PTO is not, by itself, enough to show inequitable conduct); ParkerVision, Inc. v. Qualcomm, Inc., 924 F. Supp. 2d 1314, 1318 (M.D. Fla. 2013) (noting that specific intent to deceive was not the single most reasonable inference capable of being drawn when Parkervision provided voluminous prior art references, since it was equally likely, if not more likely, that it did so to insulate itself from claims of inequitable conduct for under-disclosure). But cf. CoStar Realty Information, Inc. v. CIVIX-DDI, LLC, Nos. 12 C 4968, 12 C 7091, 12 C 8632, 2013 WL 2151548, at *12 (N.D. Ill. May 15, 2013) ("[T]he Federal Circuit has not established definitively whether or under what circumstances burying may constitute inequitable conduct.").

75. Mark A. Lemley, The Myth of the Sole Inventor, 110 Mich. L. REv. 709, 746 (2012).

76. U.S. Patent and Trademark Office, Performance and Accountability REPORT FISCAL YEAR 201225 (Nov. 7, 2012), available at http://www.uspto.gov/about/stratplan/ar/USPTOFY2012PAR.pdf. This number was significantly lower than the backlog of approximately 750,000 applications in 2008. Id.

77. Dennis Crouch \& Jason Rantanen, Average Pendency of US Patent Applications, PATENTLY-O (Mar. 20, 2013, 9:05 AM), http://www.patentlyo.com/patent/2013/03/averagependency-of-us-patent-applications.html.

78. Therasense, Inc. v. Becton, Dickinson \& Co., 649 F.3d 1276, 1289 (Fed. Cir. 2011) (en banc).

79. Jason Rantanen \& Lee Petherbridge, Therasense v. Becton Dickinson: A First Impression, 14 YALE J.L. \& TECH. 226, 257-58 (2012).

80. Dennis Crouch, Citing Patent References, Patently-O (Jan. 10, 2013, 7:24 AM), http://www.patentlyo.com/patent/2013/01/citingreferences.html.

81. Dennis Crouch \& Jason Rantanen, Citing References at the PTO, PATENTLY-O (Oct. 23, 2012, 8:05 AM), http://www.patentlyo.com/patent/2012/10/citing-references-atthe-pto.html. 
art citations in the data set were associated with just ten percent of the patents. ${ }^{82}$ Moreover, there is no significant upward trend in recent years. During the period from 2005 to 2011, the median number of references increased from thirteen to just seventeen. ${ }^{83}$ In any event, it is unclear that the inequitable conduct defense is responsible for the submission of numerous prior art references. There are many other factors that provide incentives to patent applicants to submit references to the PTO. For example, "such submissions bolster a patent against post-issuance challenges at the Patent Office and strengthen the presumption of validity that attaches to an issued patent." 84

Second, recent empirical research indicates that historically the inequitable conduct defense has worked in practice as it is supposed to work in theory. Those "patents found unenforceable have statistically significantly fewer citations to prior art than patents in other similarly tested groups." ${ }^{~} 85$ As Professors Petherbridge, Rantanen and Wagner have noted, "[t]he doctrine seems to be working as expected .... [E]liminating the doctrine of inequitable conduct may be a mistake." ${ }^{" 86}$ Third, while patent "examiners are required to consider all prior art references," ${ }^{87}$ evidence suggests that examiners use the results of their own prior art searches, rather than the purportedly voluminous references provided by applicants. ${ }^{88}$ Such evidence weakens the link between preemption of the inequitable conduct defense and delay at the PTO.

In short, the negative and unintended consequences of the inequitable conduct doctrine have been exaggerated - perhaps significantly so. But a dearth of damning empirical evidence has not discouraged critics from

\footnotetext{
82. Id.

83. Dennis Crouch \& Jason Rantanen, Average Number of References Cited Per Patent, PATENTLY-O (July 22, 2011, 9:03 AM), http://www.patentlyo.com/patent/2011/07/average-number-of-references-cited-per-

patent.html. But cf. Dennis Crouch \& Jason Rantanen, References Cited Per Patent, PAteNTLY-O (Jan. 24, 2014), http://patentlyo.com/patent/2014/01/references-citedpatent.html ("Over the past 13 years the number of references cited per patent has grown dramatically.").

84. Arpita Bhattacharyya \& Michael R. McGurk, IDS Practice After Therasense and the AIA: Decoupling the Link Between Information Disclosure and Inequitable Conduct, 29 SANTA Clara Computer \& High TeCh. L.J. 605, 611 (2013).

85. Petherbridge, Rantanen \& Wagner, supra note 71, at 22.

86. Id. at 25 .

87. TouchTunes Music Corp. v. Rowe Int'l Corp., 847 F. Supp. 2d 606, 623 (S.D.N.Y. 2012).

88. See Christopher A. Cotropia, Mark A. Lemley \& Bhaven Sampat, Do Patent Applicant Citations Matter?, 42 RESEARCH POLICY 844, 844 (2013), available at http://papers.ssrn.com/sol3/papers.cfm?abstract_id=1656568 (concluding that patent examiners rely almost exclusively on prior art they find themselves); Robert Brendan Taylor, Burying, 19 Mich. Telecomm. \& TeCH. L. ReV. 99, 115-16 (2012) (citing a study that found PTO examiners often use their own prior art searches to make their decisions).
} 
frequently describing the doctrine as an absolute plague on the courts and the United States patent system. ${ }^{89}$

To date the plague has not moved the Supreme Court, which has provided no guidance concerning inequitable conduct since it issued its opinion in Precision almost seventy years ago. The lower courts have grappled with the contours of the defense in this vacuum. Therasense represented the Federal Circuit's second attempt in two decades to reduce inequitable conduct claims in patent cases. The court's prior attempt to reduce inequitable conduct claims occurred in Kingsdown Medical Consultants, Ltd. v. Hollister, Inc. ${ }^{90}$ In that case, the court did not address materiality, but it overturned precedent ${ }^{91}$ which held that a showing of gross negligence was sufficient to establish the intent prong of the defense. Kingsdown held that the patentee's conduct must indicate sufficient culpability to require a finding of intent to deceive. ${ }^{92}$ In subsequent years, however, Federal Circuit panels routinely ignored the case ${ }^{93}$ and the requisite culpability was watered down to a "should have known" standard, which was perhaps a lower standard than gross negligence. ${ }^{94}$

Until Therasense, some courts also employed a sliding scale approach to materiality and intent that allowed a lesser showing of either element based on a stronger showing of the other. ${ }^{95}$ In theory, use of a sliding scale was restricted to situations in which there was clear and convincing proof of both materiality and intent. But in practice, use of the scale sometimes produced findings of inequitable conduct with essentially no independent support for a finding of intent. ${ }^{96}$ As noted by the Federal Circuit, use of a

89. See, e.g., Kingsdown Med. Consultants, Ltd. v. Hollister, Inc., 863 F.2d 867, 876 n.15 (Fed. Cir. 1988) (en banc); Burlington Indus., Inc. v. Dayco Corp., 849 F.2d 1418, 1422 (Fed. Cir. 1988) ("[T]he habit of charging inequitable conduct in almost every major patent case has become an absolute plague.").

90. Kingsdown, 863 F.2d 867.

91. See Driscoll v. Cebalo, 731 F.2d 878 (Fed. Cir. 1984) (holding that the intent to deceive prong of a claim of inequitable conduct may be satisfied by a showing of gross negligence; this ruling was subsequently overturned in Kingsdown).

92. Kingsdown, 863 F.2d at 876.

93. Zhe (Amy) Peng, Stacy Lewis, Deborah Herzfeld, Jill McAlpine \& Tom Irving, $A$ Panacea for Inequitable Conduct Problems or Kingsdown Version 2.0? The Therasense Decision and a Look into the Future of U.S. Patent Law Reform, 16 VA. J.L. \& TECH. 373, 390 (2011) [hereinafter Panacea].

94. See Bhattacharyya \& McGurk, supra note 84 , at 614 (stating that the "should have known" standard is lower than the "gross negligence" standard).

95. See, e.g., Bristol-Myers Squibb Co. v. Rhone-Poulenc Rorer, Inc., 326 F.3d 1226, 1234 (Fed. Cir. 2003) ("[W]hen balanced against high materiality, the showing of intent can be proportionately less.”); Am. Hoist \& Derrick Co. v. Sowa \& Sons, Inc., 725 F.2d 1350, 1363 (Fed. Cir. 1984) (noting that issues of materiality and culpability are often related and intertwined); Digital Equip. Corp. v. Diamond, 653 F.2d 701, 716 (1st Cir. 1981) (same).

96. Kass \& Browand, supra note 57. See also Jeffrey J. Oelke, Inequitable Conduct, 
sliding scale "conflated, and diluted, the standards for both intent and materiality." "The foregoing factors prompted the Federal Circuit to consider Therasense en banc.

\section{THERASENSE}

The Federal Circuit's decision in Therasense imposed significant limitations on potential use of the inequitable conduct defense. These limitations included, but were not restricted to, the adoption of elevated standards for intent and materiality.

\section{A. Procedural History of Therasense}

Therasense owned U.S. Patent No. 5,820,551 (the '551 patent), which involves disposable blood-glucose test strips for diabetes management. ${ }^{98}$ Therasense had prosecuted the original application for the patent for more than thirteen years, beginning in 1984, during which time it was repeatedly rejected over U.S. patent No. 4,454,382 (the ' 382 patent), also owned by Therasense. ${ }^{99}$ Following amendment of the claim, the examiner finally allowed the "551 patent to issue. ${ }^{100}$ In March 2004, Therasense sued several defendants, including Becton, Dickinson \& Company, alleging infringement of the '551 patent, in response to Becton's declaratory judgment action asking for recognition that its own patents did not infringe the "551 patent. ${ }^{101}$ Following trial, the federal district court held that the '551 patent was unenforceable due to inequitable conduct because Therasense did not disclose to the PTO allegedly inconsistent statements that had previously been made to the European Patent Office regarding the European counterpart to the ' 382 patent. ${ }^{102}$

Therasense appealed to the Federal Circuit, where a three-judge panel affirmed the holding of unenforceability due to inequitable conduct. ${ }^{103}$

Willful Infringement, and Antitrust Law: Navigating New Challenges in Patent Litigation, 2012 WL 6636454, at *4, ASPATORE (Nov. 2012) (attributing adoption of sliding scale in part to "the fact that direct evidence that a patentee intended to deceive the PTO is rarely available").

97. Therasense, Inc. v. Becton, Dickinson \& Co., 649 F.3d 1276, 1288 (Fed. Cir. 2011) (en banc).

98. Id. at 1282 .

99. Id. at 1283 .

100. See Therasense, Inc. v. Becton, Dickinson \& Co., 565 F. Supp. 2d 1088, 1093-94 (N.D. Cal. 2008), aff'd in part and vacated in part, 649 F.3d 1276 (Fed. Cir. 2011) (en banc).

101. 649 F.3d at 1284 .

102. Therasense, Inc. v. Becton, Dickinson \& Co., 565 F. Supp. 2d 1088, 1114-25 (N.D. Cal. 2008), aff'd in part and vacated in part, 649 F.3d 1276 (Fed. Cir. 2011) (en banc).

103. Therasense, Inc. v. Becton, Dickinson \& Co., 593 F.3d 1289, 1308 (Fed. Cir. 
Therasense then successfully petitioned for rehearing en banc. Eleven judges participated in the decision, which was six-one-four (four dissenting votes and one concurrence). The majority opinion, which vacated the judgment and remanded for further proceedings, ${ }^{104}$ noted that the court granted en banc review because it recognized the problems created by the expansion and overuse of the inequitable conduct doctrine. ${ }^{105}$

\section{B. Majority Opinion}

The majority opinion highlighted four key points. First, to prevail on its inequitable conduct defense, an accused infringer must show by clear and convincing evidence a specific intent to deceive, which requires proof that the applicant knew of the reference, knew that it was material, and made a deliberate decision to withhold it. ${ }^{106}$ There is no requirement that intent be shown by direct evidence, ${ }^{107}$ but in the absence of such direct evidence a "specific intent to deceive must be "the single most reasonable inference able to be drawn from the circumstantial evidence." 108 This holding has elevated the importance of witness credibility in assessing allegations of inequitable conduct. ${ }^{109}$ The intent requirement is not satisfied by a finding that a misrepresentation or omission constitutes negligence or even gross negligence. ${ }^{110}$ All eleven judges agreed on this last point.

Second, as a general rule, the materiality required to establish

2010), vacated, 374 Fed. App'x 35 (Fed. Cir. 2010).

104. The outcome of the further proceeding is reflected in the district court decision in Therasense, Inc. v. Becton, Dickinson \& Co., 864 F. Supp. 2d 856 (N.D. Cal. 2012). In that decision, the court again held that the " 551 patent was unenforceable due to inequitable conduct. Id. at 869 .

105. Therasense, 649 F.3d at 1285.

106. Id. at 1290 .

107. See Am. Calcar, Inc. v. Am. Honda Motor Co., No. 06cv2433 DMS (KSC), 2012 WL 1328640, at *9 (S.D. Cal. Apr. 17, 2012) ("[T]here is no requirement that intent be shown by direct evidence. Indeed, the Federal Circuit has repeatedly recognized that 'deceptive intent can be inferred from indirect and circumstantial evidence."”) (quoting Therasense, 649 F.3d at 1289).

108. Am. Calcar, 2012 WL 1328640, at *7 (quoting Therasense, 649 F.3d at 1290-91). Accord In re Rosuvastatin Calcium Patent Litig., 703 F.3d 511 (Fed. Cir. 2012).

109. See Sanya Sukduang \& Courtney B. Casp, Assessing Materiality and Intent in a Post-Therasense World, BNA's PAtent, Trademark \& Copyright Journal, Feb. 15, 2013, available http://www.finnegan.com/resources/articles/articlesdetail.aspx?news=b2937063-d5a1-42b2ba52-db47a5d35d32 (discussing the importance of witness credibility in establishing intent).

110. Therasense, 649 F.3d at 1290. Accord Outside the Box Innovations, LLC v. Travel Caddy, Inc., 695 F.3d 1285, 1292 (Fed. Cir. 2012) (underscoring that negligence alone cannot establish intent); 1st Media, LLC v. Elec. Arts, Inc., 694 F.3d 1367, 1374-75 (Fed. Cir. 2012) (" $[\mathrm{I}] \mathrm{t}$ is not enough to argue carelessness, lack of attention, poor docketing or cross-referencing, or anything else that might be considered negligent or even grossly negligent."). 
inequitable conduct is "but-for" materiality. ${ }^{111}$ In making this materiality determination, courts must "apply the preponderance of evidence standard and give claims their broadest reasonable construction." 112 An undisclosed reference is material "if the PTO would not have allowed a claim had it been aware of the undisclosed prior art." 113 A defendant must show that it is more likely than not that one or more claims of the asserted patent would have been anticipated or rendered obvious if the patent examiner had been aware of the undisclosed reference.

This new but-for standard set a higher bar for establishing materiality than the PTO's own definition under Rule 56. ${ }^{114}$ Indeed, as the Federal Circuit noted in Therasense, it specifically "decline[d] to adopt the current version of Rule 56 in defining inequitable conduct because reliance on this standard has resulted in the very problems this court sought to address by taking the case en banc."115 Only six of the eleven judges coalesced behind this new but-for standard. The Federal Circuit noted that materiality is often congruent with a validity determination - if a claim is invalidated based on prior art that was intentionally withheld, then that reference is necessarily material. This is because a finding of invalidity requires clear and convincing evidence, a more onerous evidentiary burden than that used in patent prosecution at the PTO. ${ }^{116}$ Post-Therasense, the Federal Circuit

111. Therasense, 649 F.3d at 1291.

112. Id. at 1291-92. Accord Aventis Pharma S.A. v. Hospira, Inc., 675 F.3d 1324, 1334 (Fed. Cir. 2012) (quoting the standard for establishing but-for materiality set forth in Therasense); Avocent Redmond Corp. v. Raritan Americas, Inc., 921 F. Supp. 2d 229, 243 (S.D.N.Y. 2013) (quoting the standard for establishing but-for materiality set forth in Therasense); Morningware, Inc. v. Hearthware Home Prods., Inc., 898 F. Supp. 2d 1018, 1042 (N.D. Ill. 2012) ("[T] he standard for establishing but-for materiality in the inequitable conduct context only requires a preponderance of the evidence...."); Ohio Willow Wood Co. v. ALPS South, LLC, No. 2:04-cv-1223, 2012 WL 3283437, at*15 (S.D. Ohio Aug. 10, 2012) ("Unlike the burden of proof in the intent prong, the materiality prong carries a preponderance of the evidence standard when assessing the 'but-for' materiality of a withheld reference.”). But cf. Everlight Elecs. Co. v. Nichia Corp., No. 12-cv-11758, 2013 WL 1821512, at*3 (E.D. Mich. Apr. 30, 2013) ("Both elements - intent and materiality must be established by clear and convincing evidence ....") (internal quotations omitted).

113. Therasense, 649 F.3d at 1291. Accord Aventis, 675 F.3d at 1334 (quoting Therasense in describing the test for but-for materiality); ParkerVision, Inc. v. Qualcomm, Inc., 924 F. Supp. 2d 1314, 1319 (M.D. Fla. 2013) (quoting the test for but-for materiality stated in Therasense).

114. The Federal Circuit was not bound by the definition of materiality set forth in Rule 56. Therasense, 649 F.3d at 1293-94 (citing Merck \& Co. v. Kessler, 80 F.3d 1543, 154950 (Fed. Cir. 1996)). The PTO has no rulemaking authority over the substantive questions that it addresses. Arti K. Rai, Who's Afraid of the Federal Circuit?, 121 YALE L.J. ONLINE 335, 336-37 (Dec. 20, 2011), http://yalelawjournal.org/the-yale-law-journal-pocketpart/intellectual-property/who\%E2\%80\%99s-afraid-of-the-federal-circuit?/ (citing Therasense).

115. Therasense, 649 F.3d at 1294.

116. Id. at 1292 (discussing patent invalidation in the district court). 
has reinforced the idea that but-for materiality is intertwined with invalidity. A finding of invalidity based on withheld references renders them material ${ }^{117}$ and conversely a finding of validity ordinarily precludes a finding of materiality. ${ }^{118}$

Third, there is an exception to but-for materiality in "cases of affirmative acts of egregious misconduct, such as the filing of an unmistakably false affidavit."119 In these cases the misconduct is material regardless of the effect it had had on the PTO. It is effectively per se material ${ }^{120}$ possibly regardless of the triviality of the misrepresentation. ${ }^{121}$ The Therasense majority noted that this exception to the but-for requirement is consistent with the Supreme Court's early trio of unclean hands cases (Precision, Hazel-Atlas, and Keystone). ${ }^{122}$

Fourth, intent and materiality are distinct requirements and district courts should not use a sliding scale to determine the existence of inequitable conduct. Instead, courts should assess the evidence of materiality independent of their analysis of intent. ${ }^{123}$ All eleven judges also agreed on this fourth point. ${ }^{124}$

Therasense also reaffirmed that a district court's factual findings

117. See, e.g., Aventis, 675 F.3d at 1334 (holding that but-for materiality was established because the two references withheld from the PTO were also used to invalidate the claims at issue).

118. See, e.g., Triangle Software, LLC v. Garmin Int'l, Inc., No. 1:10-cv-1457, 2012 WL 527223, at *4 (E.D. Va. Feb. 14, 2012) (holding that, after a bifurcated trial, withheld prior art could not be material because the jury determined that the same reference did not invalidate the patent). Accord Casp \& Sukduang, supra note 109 (stating that the analyses of materiality and validity are intertwined).

119. Therasense, 649 F.3d at 1292.

120. See Outside the Box Innovations, LLC v. Travel Caddy, Inc., 695 F.3d 1285, 1294 (Fed. Cir. 2012) ("In other words, a false affidavit or declaration is per se material."); In re Method of Processing Ethanol Byproducts and Related Subsystems ("858) Patent Litig., Nos. 1:10-ML-02181-LJM, 1:13-mc-00058-LJM-DML, 2013 WL 3820593, at*1 (S.D. Ind. July 23, 2013) (observing that egregious acts to deceive the PTO "serve as a proxy for materiality").

121. See Gordon \& Stack, supra note 43, at 90 (stating that the court in Therasense did not limit per se materiality to serious misconduct and may allow for trivial infractions to be per se material).

122. Therasense, 649 F.3d at 1293 (discussing the evolution of the inequitable conduct doctrine).

123. Therasense, 649 F.3d at 1290 (separating the intent and materiality determinations). Accord Am. Calcar, Inc. v. Am. Honda Motor Co., 651 F.3d 1318, 1335 (Fed. Cir. 2011) (vacating the lower court's finding of intent because the lower court did not separately analyze materiality and intent). But see B-K Lighting, Inc. v. Vision3 Lighting, 930 F. Supp. 2d 1102, 1131 (C.D. Cal. 2013) (noting sliding scale approvingly, postTherasense).

124. Therasense, 649 F.3d at 1290 (majority opinion) ("Intent and materiality are separate requirements.”); Id. at 1297 (O’Malley, J., concurring in part and dissenting in part) ("[I]ntent to deceive and materiality must be found separately."); Id. at 1304 (Bryson, J., dissenting) ("Intent to mislead and materiality must be separately proved."). 
concerning materiality and intent are subject to appellate review for clear error, and a district court's ultimate determination as to whether an act is inequitable is reviewable on appeal for abuse of discretion, and subsequent cases have agreed. ${ }^{125}$

\section{PTO Proposed Rulemaking}

Two months after the Federal Circuit issued its decision in Therasense, the PTO, which had opposed a but-for materiality standard in the en banc proceeding, ${ }^{126}$ issued a notice of proposed rulemaking with respect to Rule 56. The proposed amended rule modified the duty of disclosure by limiting the scope of materiality in a manner consistent with the but-for standard announced in Therasense. The proposed amended rule provided that information is material to patentability if it is material under the standard set forth in Therasense, and information is material to patentability under Therasense if: "(1) the [PTO] would not allow a claim if it were aware of the information, applying the preponderance of the evidence standard and giving the claim its broadest reasonable construction; or (2) the applicant engages in affirmative egregious misconduct before the [PTO] as to the information."127 The PTO noted that it was not required to harmonize the materiality standards underlying Rule 56 's duty of disclosure and the inequitable conduct doctrine, but then identified harmony and simplicity within the U.S. patent system as the primary justifications for its proposed revision. ${ }^{128}$ The proposed amended rule, like Therasense itself, gives patentees additional leeway to withhold

125. See Therasense, 649 F.3d at 1291 (discussing the inference of intent). Accord Novo Nordisk A/S v. Caraco Pharm. Labs., Ltd., 719 F.3d 1346, 1357 (Fed. Cir. 2013) (reviewing the district court's finding of inequitable conduct for abuse of discretion and the findings of materiality and intent for clear error); 1st Media, LLC v. Elec. Arts, Inc., 694 F.3d 1367, 1372 (Fed. Cir. 2012) (reviewing the underlying factual findings of intent and materiality for clear error while reviewing the finding of inequitable conduct for abuse of discretion). "A factual finding is clearly erroneous if, despite some supporting evidence, the '[appellate] court is left with the definite and firm conviction that a mistake has been committed."' Pfizer, Inc. v. Apotex, Inc., 480 F.3d 1348, 1359 (Fed. Cir. 2007) (quoting United States v. U.S. Gypsum Co., 333 U.S. 364, 395 (1948)). “A district court abuses its discretion when its decision is based on clearly erroneous findings of fact, is based on erroneous interpretations of the law, or is clearly unreasonable, arbitrary or fanciful." $1 s t$ Media, 694 F.3d at 1372 (quoting Cybor Corp. v. FAS Techs., Inc., 138 F.3d 1448, 1460 (Fed. Cir. 1998) (en banc)).

126. See Therasense, 649 F.3d at 1305 (Bryson, J., dissenting) (noting that the PTO had persuasively argued in its amicus brief that the but-for standard for materiality is too restrictive).

127. Revision of the Materiality to Patentability Standard for the Duty to Disclose Information in Patent Applications, 76 Fed. Reg. 43,631, 43,632 (proposed July 21, 2011) (to be codified at 37 C.F.R. pt. 1) (citing Therasense).

128. Id. at 43,633 (discussing the reasons for the proposed changes). 
information from the PTO during the examination process. ${ }^{129}$ The proposed amended rule had not been adopted by early-2014, and indeed rulemaking had been suspended indefinitely as the PTO grappled with implementation of the AIA. ${ }^{130}$

\section{The Negative Impact of Therasense}

Therasense and amendment of Rule 56 are likely to restrict the availability of the inequitable conduct defense in patent infringement actions to a degree that undermines the goals of the U.S. patent system. The most significant aspect of the case is the elevation of materiality to a but-for standard. As indicated, the new standard means that prior art is "but-for" material only if the PTO would not have allowed the claim if it had been aware of the undisclosed art. This rejection of current Rule 56 constituted the critical disagreement between the Therasense majority of six judges and the dissent of four. As noted by the dissent, the majority's adoption of a "[d]raconian" 131 new materiality standard departed from both principles of materiality commonly applied by courts in other contexts and the line of Supreme Court precedent set forth in the trilogy of Precision, Hazel-Atlas, and Keystone. ${ }^{132}$ In that trilogy, the Supreme Court recognized the importance of both uncompromising candor to the PTO by patent applicants and a flexible approach to equitable claims ${ }^{133}$ - something

129. Sona De, The Inequitable Conduct Defense: Before and After Therasense, 24 No. 9 INTELl. PROP. \& TECH. L.J. 15, 17 (2012) (discussing the impact of Therasense).

130. Finnegan, Henderson, Farabow, Garrett \& Dunner, LlP, Inequitable CONDUCT - Judicial Developments, 3, 15 (May 16, 2013), available at $\mathrm{http} / / /$ law.duke.edu/sites/default/files/centers/judicialstudies/patentlawintensive/thursday_Ir ving-May_16_Inequitable_Conduct.pdf (discussing how a practitioner might adjust to Rule 56); Tony Dutra, Cert Petition Attacking Therasense Standard Too Soon, Wrong Case, Solicitor General Says, BloOMBERG BNA (Sept. 11, 2013), available at http://www.bna.com/cert-petition-attacking-n17179876976/ (reporting PTO's decision to table rulemaking until after AIA's requirements of the agency are fully implemented).

131. Therasense, 649 F.3d at 1304 (Bryson, J., dissenting).

132. Therasense, 649 F.3d at 1317 (Bryson, J., dissenting) (arguing that the majority's decision in Therasense eschews precedent). Many commentators agree. See, e.g., James J. Schneider, Therasense-Less: How the Federal Circuit Let Policy Overtake Precedent in Therasense, Inc. v. Becton, Dickinson \& Co., 53 B.C. L. Rev. E-Supplement 223, 232 (2012) (stating that the rigid but-for test of materiality contravenes the flexible standard endorsed by the Supreme Court in Precision).

133. See, e.g., Hazel-Atlas Glass Co. v. Hartford-Empire Co., 322 U.S. 238, 248 (1944) ("[T] his equitable procedure has always been characterized by flexibility which enables it to meet new situations which demand equitable intervention, and to accord all the relief necessary to correct the particular injustices involved in these situations."); Keystone Driller Co. v. Gen. Excavator Co., 290 U.S. 240, 245-46 (1933) (noting that courts applying unclean hands "are not bound by formula or restrained by any limitation that tends to trammel the free and just exercise of discretion"). 
that is wholly lacking in but-for materiality.

The Supreme Court has emphasized equity's flexible nature in numerous other cases as well, ${ }^{134}$ and it has repeatedly emphasized the importance of discretionary standards in patent law. It reversed the Federal Circuit for adopting an absolute bar to the application of the doctrine of equivalents, ${ }^{135}$ for adopting a rule that patentees were automatically entitled to injunctive relief once infringement and validity were decided, ${ }^{136}$ for establishing an exclusive test for granting declaratory judgments, ${ }^{137}$ for holding that method patents could never be exhausted, ${ }^{138}$ for relying exclusively on a single test for proving obviousness, ${ }^{139}$ and for utilizing a bright-line test for patentable subject matter. ${ }^{140}$ The Federal Circuit's adoption of but-for materiality in Therasense as a response to doctrinal uncertainty regarding inequitable conduct rejects both the Supreme Court's heavy emphasis on the use of discretionary standards in patent law and traditional notions of equitable flexibility. ${ }^{141}$

The "egregious misconduct" exception was designed by the Therasense majority to mitigate the harshness of its new materiality standard. The court explained that "by creating an exception to punish affirmative egregious acts without penalizing the failure to disclose information that would not have changed the issuance decision, this court strikes a necessary balance between encouraging honesty before the PTO

134. See, e.g., Weinberger v. Romero-Barcelo, 456 U.S. 305, 312 (1982) (noting that flexibility rather than rigidity has distinguished equitable jurisdiction); Holmberg $v$. Armbrecht, 327 U.S. 392, 396 (1945) ("Equity eschews mechanical rules; it depends on flexibility.").

135. Festo Corp. v. Shoketzu Kinzoku Kogyo Kabushiki Co., 535 U.S. 722, 738 (2002) (emphasizing that the Supreme Court consistently uses a flexible, not rigid, approach when applying the doctrine of equivalents).

136. eBay Inc. v. MercExchange, L.L.C., 547 U.S. 388, 394 (2006) (holding that the Federal Circuit erred in its categorical grant of injunctive relief).

137. MedImmune, Inc. v. Genentech, Inc., 549 U.S. 118, 137 (2007) (holding that a patent licensee need not terminate or breach a license agreement in order to meet the "actual case or controversy" requirement under Article III of the Constitution and seek declaratory judgment).

138. Quanta Computer, Inc. v. LG Elecs., Inc., 553 U.S. 617, 628-30 (2008) (holding that the exhaustion doctrine applies to method patents).

139. KSR Int'l Co. v. Teleflex Inc., 550 U.S. 398, 419-22 (2007) (holding that the TSM test for obviousness should not be used as a rigid formula and noting that "[r]igid preventative rules that deny factfinders recourse to common sense . . . are neither necessary under our case law nor consistent with it"). Id. at 421.

140. Bilski v. Kappos, 130 S. Ct. 3218, 3227 (2010) (rejecting the argument that the machine-or-transformation test is the exclusive test for determining what constitutes a patentable process).

141. The failure of the Federal Circuit in Therasense to adhere to inequitable conduct's equitable tradition is critiqued in T. Leigh Anenson \& Gideon Mark, Inequitable Conduct in Retrospective: Understanding Unclean Hands in Patent Remedies, 62 AM. U. L. REV. 1441 (2013). 
and preventing unfounded accusations of inequitable conduct." ${ }^{142}$ But the exception has no clear definition and applies only to affirmative misrepresentations. ${ }^{143}$ It does not apply in cases of nondisclosure or failure to mention prior art references in an affidavit. ${ }^{144}$ Neither of these events renders an affidavit unmistakably false - the one specific example of egregious misconduct that the court provided. ${ }^{145}$ And it is "unclear whether ... complete lack of diligence in submitting relevant information to the Patent Office, or deliberate attempts to remain unaware of potentially relevant information" would constitute egregious misconduct. ${ }^{146}$ In short, the exception will be rare, ${ }^{147}$ and will do little to mitigate the rigidity of the new but-for standard.

Moreover, the exception, similar to the general standard, eschews both traditional notions of equity and the Supreme Court's endorsement of the use of discretionary standards in patent law. The carve-out to but-for materiality only applies if the rigid threshold of egregious affirmative misconduct is met. Such rigidity permits no opportunity for courts to exercise their equitable discretion.

Difficulty in establishing materiality post-Therasense is not the only obstacle confronted by accused patent infringers seeking to utilize the inequitable conduct defense. Another obstacle is presented by Therasense's holding about intent. Direct evidence of intent to deceive the PTO is scarce, ${ }^{148}$ primarily because the decision to refrain from disclosure

142. Therasense, Inc. v. Becton, Dickinson \& Co., 649 F.3d 1276, 1293 (Fed. Cir. 2011) (en banc).

143. Id. at 1293; Cotter, supra note 22, at 745 .

144. Therasense, 649 F.3d at 1292-93; Senju Pharm. Co. v. Apotex, Inc., 921 F. Supp. 2d 297, 308 n.15 (D. Del. 2013) ("Omissions ... cannot constitute affirmative egregious misconduct.").

145. See TV Interactive Data Corp. v. Sony Corp., No. C 10-0475 PJH, 2012 WL 6020113 , at $* 27$ (N.D. Cal. Dec. 3, 2012) (observing that filing a false affidavit is "the sole type of 'egregious affirmative act' identified by the Federal Circuit as providing an exception to the requirement of 'but-for' materiality"). But cf. Smith \& Nephew, Inc. v. Interlace Med., Inc., No. 10-10951-RWZ, 2013 WL 3289085, at*2 (D. Mass. June 27, 2013) (asserting that affirmative egregious misconduct, as described in Therasense, also includes "suborning perjury, bribing witnesses, and actively suppressing evidence").

146. Bhattacharyya \& McGurk, supra note 84 , at 632.

147. See Gino Cheng, Robert M. Isackson \& Thomas J. Gray, Inequitable Conduct: Rethinking 'Egregious Misconduct', LAw360 (Jan. 9, 2013, 12:16 PM), http://about.bloomberglaw.com/practitioner-contributions/inequitable-conduct-analysis/

("Far from the inside track to leapfrog over the 'but-for' materiality test set forth by the bare majority in Therasense ... the defense tactic of alleging egregious misconduct appears to be a detour - at least for now."). Post-Therasense courts have been very reluctant to apply the egregious misconduct exception. See, e.g., Galderma Labs., L.P. v. Tolmar, Inc., 891 F. Supp. 2d 588, 649 n.21 (D. Del. 2012) (rejecting application of exception because statements to PTO "were merely a statement of the hypothesis to be tested during the regulatory approval process").

148. Therasense, 649 F.3d at 1290. 
is rarely documented. Even where direct evidence of intent does exist, it likely is shielded from discovery by the attorney-client privilege. ${ }^{149}$ Patent applicants, by involving an attorney in important discussions throughout the patent application process, may claim privilege over numerous categories of documents, including potentially "smoking gun" documents. $^{150}$ Thus, such documents are unlikely to emerge during discovery, and direct evidence of intent will be rare.

Moreover, under applicable Federal Circuit law, the assertion of attorney-client privilege and/or the work product doctrine and the withholding of advice of counsel cannot yield an adverse inference as to the nature of the advice. ${ }^{151}$ This jurisprudence essentially forces federal district courts to make positive inferences and "produces a tremendous structural advantage for the party accused of inequitable conduct, while encouraging the abuse of privilege." 152 The crime-fraud exception ${ }^{153}$ to the attorney-client privilege is unlikely to reduce this advantage in most cases, because under Federal Circuit law, "a party must establish Walker Process fraud ... to successfully pierce the attorney-client privilege." 154 As is set forth infra, Walker Process fraud will be virtually impossible to prove postTherasense.

The unavailability of direct evidence of intent is critical. In the absence of direct evidence, a post-Therasense court may find specific intent to deceive the PTO only if it is the most reasonable inference arising from the circumstantial evidence. ${ }^{155}$ As the Federal Circuit noted, "[i]f multiple

149. See, e.g., Gen. Elec. Co. v. Mitsubishi Heavy Indus. Ltd., No. 3:10-CV-276-F, 2013 WL 2338345, at*5 (N.D. Tex. May 28, 2013) (noting that the record in the case had significant gaps because many documents were protected by the attorney-client privilege, and lamenting that these gaps made adjudication of intent a difficult task).

150. Id. at *5 (noting the unlikelihood of such potentially incriminatory documents ever surfacing in inequitable conduct cases).

151. See Knorr-Breme Systeme Fuer Nutzfahrzeuge GmbH v. Dana Corp., 383 F.3d 1337, 1345 (Fed. Cir. 2004) (extending to patent cases the rule that declines to impose adverse inferences on invocation of the attorney-client privilege); accord Golden Blount, Inc. v. Robert H. Peterson Co., 438 F.3d 1354, 1368 (Fed. Cir. 2006) (holding that a threshold showing of culpable behavior "cannot be satisfied merely by proof that the accused is asserting the attorney-client privilege to withhold an opinion of counsel").

152. Gen. Elec. Co., 2013 WL 2338345 at*8.

153. "The party seeking discovery of privileged communications or documents must prove the crime-fraud exception applies by showing: (1) a prima facie case of criminal or fraudulent conduct, and (2) the communications were made in furtherance of the crime or fraud." Shelbyzyme, LLC v. Genzyme Corp., No. 09-768-GMS, 2013 WL 3229964, at*1 n.1 (D. Del. June 25, 2013) (quoting Magnetar Techs. Corp. v. Six Flags Theme Park Inc., 886 F. Supp. 2d 466, 482 (D. Del. 2012)).

154. Unigene Labs., Inc. v. Apotex, Inc., 655 F.3d 1352, 1358-59 (Fed. Cir. 2011).

155. Therasense, 649 F.3d at 1290. Accord 01 Communique Lab., Inc. v. LogMeIn, Inc., No. 1:10-cv-1007, 2013 WL 3270648, at*2 (E.D. Va. June 25, 2013). 
reasonable inferences can be drawn, "intent to deceive cannot be found." 156 Post-Therasense, the Federal Circuit has "rigorously enforced" the most reasonable inference requirement. ${ }^{157}$

The harsh Therasense requirements have at least two negative effects. First, because they are, in the words of one federal district court, "nearly insurmountable," 158 they bar numerous potentially meritorious claims. Post-Therasense courts have been very reluctant to infer intent based on circumstantial evidence. In the first six months after the en banc Therasense decision was issued, district courts rendered final decisions in fourteen cases involving inequitable conduct. These courts found the specific intent required by Therasense in only one of the cases, and they found inequitable conduct in none of them. ${ }^{159}$

Second, they create a roadmap to success for dishonest patent applicants and thus encourage misconduct. Post-Therasense, a dishonest patent applicant is less likely to be found to have engaged in inequitable conduct if it makes no disclosure of prior art than if it makes selective disclosure. If it makes no disclosure then there is likely to be no written evidence of intent to deceive and therefore immunization of inaction. Conversely, if the applicant makes selective disclosure there will be some written evidence that it made the deliberate decision to disclose some art while withholding other references. Therasense thus creates a perverse incentive to withhold material information from the PTO. ${ }^{160}$

Therasense's elevated standards concerning materiality and intent are not only applicable at trial. The standards also apply at the summary

156. TV Interactive Data Corp. v. Sony Corp., No. C 10-0475 PJH, 2012 WL 6020113, at $* 23$ (N.D. Cal. Dec. 3, 2012) (quoting Therasense, 649 F.3d at 1920-91).

157. Lisa A. Dolak, Litigating Inequitable Conduct After Therasense, Exergen and the AIA: Lessons for Litigants, Options for Owners, 13 CHI.-Kent J. InTELl. Prop. 51, 57 (2013). A pattern of deceit strengthens an inference of intent to deceive. Intellect Wireless, Inc. v. HTC Corp., 732 F.3d 1339, 1345 (Fed. Cir. 2013) (finding such a pattern in this case).

158. Gen. Elec. Co. v. Mitsubishi Heavy Indus. Ltd., No. 3:10-CV-276-F, 2013 WL 2338345, at *5 (N.D. Tex. May 28, 2013) (observing that the requirement of "deliberateness" creates a hurdle that is "unlikely to be jumped in all but the rarest cases").

159. Peter G. Thurlow \& Maya Elbert, Inequitable Conduct: Analysis of PostTherasense Decisions and the Supplemental Examination Provision of the America Invents Act, 5 Bloomberg LaW Reports - Intellectual Property 48 (Nov. 16, 2011). The authors conclude that "[a]s difficult as it may be for a patent challenger to establish materiality, it may be even more difficult to establish the requisite level of intent." Id.

160. See Brandee N. Woolard, Issue Brief, The Resurrection of the Duty to Inquire After Therasense, Inc. v. Becton, Dickinson \& Co., 12 Duke L. \& TeCH. REv. 42, 44 (2014) (noting that Therasense "disincentivizes patent practitioners from seeking out material information."); Maurice Ross, A Year of Dramatic Change in Intellectual Property Law: Who are the Winners and Losers?, ASPATORE, 2013 WL 571327, at *8 (Jan. 2013) (observing that Therasense and AIA collectively provide "perverse incentives for cheating and fraud."). 
judgment stage, ${ }^{161}$ where the burden of proving inequitable conduct is particularly onerous. ${ }^{162}$ The standards also operate to effectively raise the standard for pleading inequitable conduct. The Federal Circuit established the current strict pleading standard two years prior to Therasense, when it held in Exergen Corp. v. Wal-Mart Stores, Inc. ${ }^{163}$ that inequitable conduct must be pleaded with particularity under Rule 9(b) of the Federal Rules of Civil Procedure ${ }^{164}$ by identifying "the specific who, what, when, where, and how of the material misrepresentation or omission committed before the PTO." 165 Failure to identify each of these factual elements constitutes an incurable deficiency under Rule 9(b). ${ }^{166}$

In Exergen, the Federal Circuit applied its own law to determine the appropriate pleading standard, but it adopted the approach for pleading fraud previously articulated by the Seventh Circuit. ${ }^{167}$ This adoption disregarded both the text of Rule 9(b), which expressly requires particularity only when pleading fraud or mistake, ${ }^{168}$ and the law of inequitable conduct, which does not include reliance as an element and thus is broader than common law fraud. ${ }^{169}$ Prior to Exergen, the Federal Circuit underscored that "[i]nequitable conduct... is a lesser offense than common law fraud." 170 In Exergen, the court substantially raised the standard for pleading inequitable conduct, whether as a counterclaim or as an affirmative defense, ${ }^{171}$ by importing the inapposite standard for pleading

161. See Amdocs (Israel) Ltd. v. Openet Telecom, Inc., No. 1:10cv910 LMB/TRJ, 2013 WL 265602, at*30 (E.D. Va. Jan. 22, 2013).

162. See Leviton Mfg. Co. v. Universal Sec. Instr., Inc., 606 F.3d 1353, 1363 (Fed. Cir. 2010) ("We rarely affirm a grant of summary judgment of inequitable conduct ...."); Morningware, Inc. v. Hearthware Home Products, Inc., 898 F. Supp. 2d 1018, 1041 (N.D. Ill. 2012) ("[The] burden of proving inequitable conduct at the summary judgment stage is particularly onerous ...."); TecSec, Inc. v. Int'l Business Mach. Corp., 763 F. Supp. 2d 800, 809 (E.D. Va. 2011) ("The Federal Circuit has repeatedly indicated that inequitable conduct defenses are disfavored, particularly at the summary judgment stage.").

163. 575 F.3d 1312 (Fed. Cir. 2009).

164. FED. R. CiV. P. 9(b).

165. Exergen, 575 F.3d at 1328.

166. Prowess, Inc. v. RaySearch Labs., AB, No. WDQ-11-1357, 2013 WL 3480319, at *7 (D. Md. July 9, 2013).

167. Exergen, 575 F.3d at 1326-27. The earlier Seventh Circuit decision is DiLeo v. Ernst \& Young, 901 F.2d 624, 627 ( $7^{\text {th }}$ Cir. 1990).

168. Fed. R. Civ. P. 9(b).

169. Dippin' Dots, Inc. v. Mosey, 476 F.3d 1337, 1346 (Fed. Cir. 2007) (noting that inequitable conduct "is a broader, more inclusive concept" than common law fraud).

170. Nobelpharma AB v. Implant Innovations, Inc., 141 F.3d 1059, 1069 (Fed. Cir. 1989). See also David Hricik, Wrong About Everything: The Application by the District Courts of Rule 9(b) to Inequitable Conduct, 86 MARQ. L. LEV. 895, 913 (2003) ("[T]he Federal Circuit has... recognized that inequitable conduct does not require proof of fraud.").

171. See Senju Pharm. Co. v. Apotex, Inc., 921 F. Supp. 2d 297, 306 (D. Del. 2013) ("Apotex's counterclaim and affirmative defense for inequitable conduct rise or fall 
fraud. $^{172}$

Exergen's "who" requirement requires identification of the specific individual(s) alleged to have engaged in inequitable conduct. General references to categories of persons, such as inventors or corporate entities, do not suffice, ${ }^{173}$ in part because "the duty of candor and good faith in dealing with the PTO is inapplicable to organizations." 174 The "what" requirement involves both the nature of the inequitable conduct (for example, whether there was a material omission or material misrepresentation) and the relevance of that conduct to specific patent claims. $^{175}$

Compliance with Exergen's "where" requirement is a function of the nature of the alleged inequitable misconduct. If the conduct involves a failure to disclose prior art, then defendant is required to specifically identify the location of the material information within the reference. ${ }^{176}$ If the conduct involves a failure to disclose relevant sales, offers for sales, or litigation, then defendant is required to specifically identify the location of the activity. A general identification is insufficient. ${ }^{177}$ Compliance with

together.”); XpertUniverse, Inc. v. Cisco Sys., Inc., 868 F. Supp. 2d 376, 379-83 (D. Del. 2012) (assessing the sufficiency of counterclaims and affirmative defenses of inequitable conduct together); Southco, Inc. v. Penn Eng'g \& Mfg. Co., 768 F. Supp. 2d 715, 721-24 (D. Del. 2011) (same); cf. ParkerVision, Inc. v. Qualcomm, Inc., 924 F. Supp. 2d 1314, 1321 (M.D. Fla. 2013) (construing affirmative defense of inequitable conduct as a counterclaim and then striking it as redundant of existing counterclaim for inequitable conduct).

172. See, e.g., Adam R. Andrea, Case Note and Comment, Exergen v. Wal-Mart: $A$ Costly Cure for the Plague of Inequitable Conduct Claims, 20 DePAUl J. ART, TECH. \& INTELL. Prop. L. 449, 462 (2010) ("The court provided virtually no justification for its application of Rule 9(b) to inequitable conduct."); see also David O. Taylor, Patent Fraud, 83 Temple L. Rev. 49, 73 (2010) ("Exergen may represent the first foray into the adoption of principles from the law of fraud into the law of inequitable conduct.").

173. See, e.g., Sepracor, Inc. v. Teva Pharm. USA, Inc., Civil Action No. 09-cv-01302 (DMC)(MF), 2010 WL 2326262, at *6 (D.N.J. June 7, 2010) (holding that general references to "patent applicants and Sepracor" were insufficient).

174. Senju, 921 F. Supp. 2d at 307.

175. Exergen Corp. v. Wal-Mart Stores, Inc., 575 F.3d 1312, 1329 (Fed. Cir. 2009) ("The pleading fails to identify which claims, and which limitations in those claims, the withheld references are relevant to ....").

176. Bruce D. DeRenzi \& Sean E. Jackson, A Procedural Remedy for the 'Plague'? Pleading Inequitable Conduct after Exergen Corp. v. Wal-Mart Stores, Inc., NYIPLA Bulletin (N.Y. Intellectual Prop. Ass'n), Aug./Sept. 2010, at 9-11, available at http://www.crowell.com/documents/A-Procedural-Remedy-for-the-Plague-Pleading-

Inequitable-Conduct-After-Exergen-Corp-v-Wal-Mart.pdf See also Aevoe Corp. v. AE Tech. Co., No. 2:12-cv-00053-GMN-NJK, 2013 WL 876036, at*7 (D. Nev. Mar. 7, 2013) (noting that to satisfy "where" requirement, the pleading must specifically identify to which claims, and which limitations in those claims, the withheld references are relevant).

177. See, e.g., Halo Elecs., Inc. v. Bel Fuse Inc., No. C-07-06222 RMW, 2010 WL 246811 , at $* 2$ (N.D. Cal. June 14, 2010) (holding that allegation of product sales "in the United States" was insufficient). 
Exergen's "when" requirement similarly is a function of the nature of the alleged conduct. A simple allegation that inequitable conduct occurred during patent prosecution may suffice in some cases, but in many other cases defendants may be required to identify the publication dates of references, press release issue dates, and contract execution dates. ${ }^{178}$

Compliance with the "how" requirement entails an explanation of "how a patent examiner would have used undisclosed information in determining the patentability of the claims." 179 This has been described as the "most onerous step in the Exergen analysis."180 The pleading must explain the manner in which the information is "material and noncumulative." 181 The controlling inquiry is whether the allegations "put Plaintiffs on notice as to what information Defendants contend should have been provided to the examiner but wasn't, and how that information would have changed the examiner's decision." "182 There is some confusion among the federal district courts as to whether Exergen also imposes a separate "why" requirement. It is not clear that either Rule 9(b) or the prior Seventh Circuit decision on which Exergen is based mandates such a showing. ${ }^{183}$ In any event, a pleading which satisfies the "how" element likely also satisfies the "why" element. ${ }^{184}$ As in the case of "how," satisfaction of the "why" element requires pleading "with specificity that the undisclosed information is not cumulative of the information that was disclosed during prosecution." $" 185$

Therasense did not specifically address the pleading requirements for an inequitable conduct defense, ${ }^{186}$ and by January 2014, no federal decision

178. DeRenzi \& Jackson, supra note 176, at 11.

179. Aevoe Corp., 2013 WL 876036 at *8.

180. See McKechnie Vehicle Components USA, Inc. v. Lacks Indus., Inc., No. 09-cv11594, 2010 WL 4643081, at *5 (E.D. Mich. Nov. 9, 2010).

181. Aevoe Corp., 2013 WL 876036, at*5.

182. Lincoln Nat'l Life v. Jackson Nat'l Life Ins. Co., 1:07-cv-265, 2010 WL 1781013, at $* 8$ (N.D. Ind. May 3, 2010).

183. See, e.g., Lincoln Nat'l Life, $2010 \mathrm{WL} 1781013$ at *6 (holding that there is no separate "why" requirement); Johnson Outdoors Inc. v. Navico, Inc., 774 F. Supp. 2d 1191, 1197 (M.D. Ala. 2011) (suggesting that there is no "independent "why' requirement.").

184. See DeRenzi \& Jackson, supra note 176, at 12 (observing that pleading requirements for inequitable conduct meld together the "how" and "why" elements).

185. Aevoe Corp. v. AE Tech. Co., No. 2:12-cv-00053-GMN-NJK, 2013 WL 876036, at *8 (D. Nev. Mar. 7, 2013). See Oracle Corp. v. DrugLogic, Inc., 807 F. Supp. 2d 885, 897 (N.D. Cal. 2011) (dismissing inequitable conduct defense and counterclaim in part for failure to allege facts to support inference that withheld information was not cumulative).

186. See Cutsforth, Inc. v. LEMM Liquidating Co., No. 12-cv-1200 (SRN/JSM), 2013 WL 2455979, at *4 (D. Minn. June 6, 2013) ("Therasense did not address inequitable conduct claims at the pleading stage nor did it override Exergen's pleading requirements."); Waters Indus., Inc. v. JJI Int'l, Inc., No. 11 C 3791, 2012 WL 5966534, at *4 (N.D. Ill. Nov. 28, 2012) (same); Bayer Cropscience AG v. Dow Agrosciences LLC, Civil No. 10-1045 (RMB/JS), 2012 WL 1253047, at *2 (D. Del. Apr. 12, 2012). 
pre- or post-Therasense held that the facts set forth in a pleading alleging inequitable conduct must meet the clear and convincing standard. ${ }^{187}$ But Therasense did raise the hurdle in substance insofar as all of the elements of the new inequitable conduct standard now must be pled with particularity, ${ }^{188}$ and if they are not an inequitable conduct counterclaim must be dismissed and a parallel affirmative defense must be stricken. ${ }^{189}$ This is true even though Rule 9(b), which requires allegations of fraud to be pleaded with particularity, permits the intent element to be pleaded without specificity. ${ }^{190}$ This elevated pleading standard "is the most onerous in all of civil litigation." ${ }^{, 191}$ Moreover, several district courts have held that "Therasense raised the pleading bar so that specific intent to deceive must be the single most reasonable inference able to be drawn" from the facts alleged, rather than merely a reasonable inference. ${ }^{192}$ Accordingly, while

187. See Milwaukee Elec. Tool Corp. v. Hitachi Koki Co., No. 09-948, 2012 WL 1952977, at *6 (E.D. Wis. May 29, 2012) (holding that Therasense does not apply to the pleading stage, and applying Exergen); W.L. Gore \& Assocs., Inc. v. Medtronics, Inc., 850 F. Supp. 2d 630, 635 (E.D. Va. 2013) (“Although the facts alleged in [defendant's] counterclaim may not be enough to satisfy the Therasense elements by clear and convincing evidence, the alleged facts are sufficient to satisfy Exergen's pleading requirements."); Human Genome Scis., Inc. v. Genentech, Inc., No. 2:11-cv-6519-MRP (JEMx), 2011 WL 7461786, at *3 (C.D. Cal. Dec. 9, 2011) ("No Federal Circuit decision, before Therasense or after Therasense, has stated that the facts in a pleading for inequitable conduct must meet the clear and convincing standard.").

188. Evonik Degussa GMBH v. Materia Inc., No. 09-cv-636 (NLH-JS), 2012 WL 4503771 , at $* 4$ (D. Del. Oct. 1, 2012) ("[T]he proper standard to apply at this stage in the proceedings is the standard set forth in Exergen. As stated in Exergen, a claim for inequitable conduct must be plead with particularity under Rule 9(b)."); Thurlow \& Elbert, supra note 159, at 25 ("Therasense, without changing the Exergen standard for pleading inequitable conduct in form, heightens it in substance since all of the elements of the new inequitable conduct standard, including 'but-for' materiality and specific intent, must be supported with particularized allegations.”); $c f$. Butamax v. Gevo, Inc., Civ. No. 11-54-SLR, 2013 WL 571801, at *2 (D. Del. Feb. 13, 2013) ("[T]he standard for proving inequitable conduct is a more rigorous one than the standard for pleading inequitable conduct; apparently, even the Federal Circuit has been tempted to confuse the same.").

189. B-K Lighting, Inc. v. Vision3 Lighting, No. CV 06-02825 MMM (PLAx), 2013 WL 941839, at*21 (C.D. Cal. Mar. 11, 2013); see also Mycone Dental Supply Co. v. Creative Nail Design, Inc., Civil Action No. 11-4380 (JBS-KMW), 2013 WL 3216145, at *6 (D.N.J. June 24, 2013) ("[T]he heightened standards for proving inequitable conduct recently set by the Federal Circuit are reflected in the heightened standards that are required for pleading inequitable conduct at the Rule 12(b)(6) stage.").

190. FED. R. CIV. P. 9(b) ("[A] party must state with particularity the circumstances constituting fraud or mistake. Malice, intent, knowledge, and other conditions of a person's mind may be alleged generally.").

191. Chiang, supra note 3, at 1268.

192. Hansen Mfg. Corp. v. Enduro Sys., Inc., No. 11-cv-4030, 2011 WL 5526627, at *4 (D.S.D. Nov. 14, 2011); see also Quest Software, Inc. v. Centrify Corp., No. 2:10-cv-859, 2011 WL 5508820, at*2-3 (D. Utah Nov. 9, 2011). Other courts have disagreed and held that claimant need only allege facts from which the court could reasonably infer that the patent applicant made a deliberate decision to deceive the PTO. See, e.g., Cutsforth, Inc. v. 
Exergen alone had no significant downward impact on the number of cases alleging inequitable conduct, ${ }^{193}$ Exergen in combination with Therasense has had a substantial chilling effect. The heightened pleading burden in tandem with the heightened substantive burden has operated to deter and foreclose many assertions of the inequitable conduct defense, particularly because Federal Circuit law controls with respect to both the pleading ${ }^{194}$ and the proof ${ }^{195}$ of inequitable conduct. During the period from 2008 to 2012 the percentage of Answers that were filed in patent cases that contained the term "inequitable conduct" declined sharply from forty-one percent to twenty-one percent. ${ }^{196}$ This decline is likely a reaction to the virtually insurmountable barriers created by Exergen and Therasense. In the last six months of 2011, seventeen of nineteen district court rulings on the pleadings resulted in the dismissal of inequitable conduct claims. ${ }^{197}$

LEMM Liquidating Co., No. 12-cv-1200 (SRN/JSM), 2013 WL 2455979, at *4 (D. Minn. June 6,2013 ) (holding that court must determine whether it could "reasonably infer that the [USPTO] would not have allowed the claim if it had been aware of the undisclosed reference"); CoStar Realty Info., Inc. v. CIVIX-DDI, LLC, Nos. 12 C 4968, 12 C 7091, 12 C 8632, 2013 WL 2151548, at*11 (N.D. Ill. May 15, 2013) (holding that "[a]t the pleading stage, the proponent of inequitable conduct need only plead sufficient facts that the court 'may reasonably infer' knowledge and intent."); Aeveo Corp. v. AE Tech Co., No. 2:12-cv00053 -GMN-NJK, 2013 WL 876036, at *10 (D. Nev. Mar. 7, 2013) (determining that the claimant need only allege facts from which court could make reasonable inferences regarding deliberate deceit).

193. Panacea, supra note 93, at 396 (concluding that Exergen "has not appeared to stem the tide of inequitable conduct allegations"). But cf. Andrea, supra note 172, at 469 (concluding that Exergen will hinder the assertion of many legitimate inequitable conduct claims, thereby creating "incentives for unscrupulous applicants and attorneys to conceal material information from the PTO"); Lisa A. Dolak, Beware the Inequitable Conduct Charge! (Why Practitioners Submit What They Submit), 91 J. Pat. \& Trademark OfF. SOC'Y 558, 568 (2009) (observing that Exergen "has the potential to dramatically alter the inequitable conduct landscape by curbing misconduct allegations at their source - the pleadings"); Benjamin Johnson, Note, The Federal Circuit's Inequitable Conduct Standard After Exergen v. Wal-Mart: A Step in the Right Direction, but Will it Really Change Anything?, 8 Nw. J. TECH. \& INTELL. Prop. 360, 370 (2010) (predicting that post-Exergen, defendants in patent infringement cases "will be considerably more conservative in their use of the inequitable conduct" defense).

194. See Exergen Corp. v. Wal-Mart Stores, Inc., 575 F.3d 1312, 1326 (Fed. Cir. 2009) (noting that "whether inequitable conduct has been adequately pleaded is a question of Federal Circuit law"). Accord Cumberland Pharm., Inc. v. Mylan Institut., LLC, No. 12 C 3846, 2012 WL 6567922, at *3 (N.D. Ill. Dec. 14, 2012) (holding that Federal Circuit law governs heightened pleading requirement).

195. See Exergen, 575 F.3d at 1327 n.3 (enumerating the elements of inequitable conduct); Zep Solar, Inc. v. Westinghouse Solar, Inc., No. C 11-06493 JSW, 2012 WL 1293873, at *2 (N.D. Cal. Apr. 16, 2012) (stating that "Federal Circuit law governs sufficiency of allegations of inequitable conduct").

196. Rantanen, supra note 64, at 101.

197. See Carlson, supra note 70, at 10 . Where inequitable conduct pleadings have been found insufficient, courts have not infrequently granted leave to amend. But leave is neither assured nor a guarantee of success. See, e.g., Semiconductor Energy Lab. Co. v. Samsung 
And during the period from June 2011 to April 2013, the Federal Circuit affirmed a district court's finding of inequitable conduct only once. ${ }^{198}$

The foregoing effects are magnified because there is no effective substitute for the inequitable conduct defense. The doctrine of unclean hands, from which inequitable conduct derives, and which remains intact post-Therasense, ${ }^{199}$ is a distinct doctrine with its own considerations. ${ }^{200}$ Unclean hands generally cannot be raised by a party who is foreign to the alleged unclean conduct at the time of its occurrence. ${ }^{201}$ In addition, whereas application of the inequitable conduct doctrine results in the unenforceability of the entire patent, the unclean hands defense merely allows courts to dismiss complaints filed by plaintiffs suing in bad faith. ${ }^{202}$

The Supreme Court has never granted certiorari on a petition involving inequitable conduct in its modern incarnation. ${ }^{203}$ Unless it does so, the Federal Circuit's harsh restrictions on the use of the inequitable conduct defense will be operative for the foreseeable future. These restrictions, particularly Therasense's adoption of but-for materiality, will have numerous negative effects. First, they will function to reduce the incentive for patent applicants to be candid with the PTO and thereby

Elecs. Co., 749 F. Supp. 2d 892, 903 (W.D. Wis. 2010) (denying in part and granting in part request for leave to amend inequitable conduct counterclaims).

198. Rantanen, supra note 64, at 111; see also Chiang, supra note 3, at 1286 (noting that the Federal Circuit is approaching the point of never finding inequitable conduct to be proven).

199. See Therasense, 649 F.3d at 1287 (noting that "the unclean hands doctrine remains available to supply a remedy for egregious misconduct"). Egregious misconduct might provide a basis for equitable relief other than patent unenforceability where it falls short of inequitable conduct.

200. See, e.g., Nordock Inc. v. Sys. Inc., 927 F. Supp. 2d 577, 605 (E.D. Wis. 2013) (holding that the trial court has broad discretion under the unclean hands doctrine).

201. See Gen. Elec. Co. v. Mitsubishi Heavy Indus. Ltd., No. 3:10-CV-276-F, 2013 WL 2338345 , at *28 (N.D. Tex. May 28, 2013) (noting that "misconduct unrelated to the matter at litigation is not relevant to the demonstration of inequitable conduct during the prosecution of the patent at issue"); Nicole M. Murphy, Note, Inequitable Conduct Doctrine Reform: Is the Death Penalty for Patents Still Appropriate?, 93 MinN. L. REV. 2274, 2286 (2009) (noting that a party foreign to the alleged misconduct cannot raise unclean hands defense).

202. See Metris U.S.A., Inc. v. Faro Tech., Inc., 882 F. Supp. 2d 160, 169, 175-76 (D. Mass. 2011) (citing Therasense for the proposition that a finding of inequitable conduct results in unenforceability of an entire patent); Keystone Driller Co. v. Gen. Excavator Co., 290 U.S. 240, 245-46 (1933) (affirming dismissal of patent infringement action on basis of unclean hands).

203. No petition was filed by defendants in Therasense. In October 2013 the Supreme Court denied certiorari in a post-Therasense case concerning the inequitable conduct doctrine. See Sony Computer Entm't Am. LLC v. 1st Media, LLC, 134 S. Ct. 418 (2013); David Hricik, Supremes Deny Cert in Sony v. First Media: An Update, Patently-O (Oct. 15, 2013), http://patentlyo.com/hricik/2013/10/supremes-deny-cert-in-sony-v-firstmedia.html. 
undermine one of the primary goals of the U.S. patent system. ${ }^{204}$

Second, the restrictions will reduce patent quality, ${ }^{205}$ insofar as the duty of candor owed by patent applicants to the PTO helps ensure quality patents. Critics have long complained that the PTO, which in 2013 granted approximately 278,000 patents, ${ }^{206}$ grants far too many low-quality patents. ${ }^{207}$ According to one frequently cited study, courts have found invalid forty-six percent of patents litigated to judgment. ${ }^{208}$ Patent quality

204. See Taylor, supra note 88, at 125 (observing that adoption by PTO of Therasense materiality standard "may encourage applicants to withhold relevant prior art."). See also Elizabeth Peters, Note, Are We Living in a Material World?: An Analysis of the Federal Circuit's Materiality Standard under the Patent Doctrine of Inequitable Conduct, 93 IowA L. REV. 1519, 1522 (2008) (noting vital role that doctrine of inequitable conduct plays in preserving fairness of U.S. patent system).

205. "Patent quality" has been defined as "the capacity of a granted patent to meet (or exceed) the statutory standards of patentability - most importantly, to [cover inventions which are] novel, nonobvious, and clearly and sufficiently described." R. Polk Wagner, Understanding Patent-Quality Mechanisms, 157 U. PA. L. REV. 2135, 2138 (2009). Accord Sean B. Seymour, The Presumption of Patentability, 97 MinN. L. REV. 990, 990-91 (2013) (reinforcing the consensus opinion that a patent's quality is measured in terms of its novelty, obviousness, and clarity of description). A high-quality patent is "one that covers an invention that would not otherwise be made [but for the incentive of a patent] or one that ensures that a good idea is commercialized ...." Bronwyn H. Hall \& Dietmar Harhoff, Post-Grant Reviews in the U.S. Patent System-Design Choices and Expected Impact, 19 Berkeley TeCH. L.J. 989, 991 (2004); accord Seymour at 991 n.3 (noting the positive business effects of patents created by their encouragement of inventive processes).

206. Dennis Crouch \& Jason Rantanen, Utility Patents Granted in 2013: A New Record (for the Fourth Consecutive Year), PATENTLY-O (Jan. 2, 2014), http://patentlyo.com/patent/2014/01/utility-patents-granted-in-2013-a-new-record-for-thefourth-consecutive-year.html.

207. See, e.g., Anup Malani \& Jonathan S. Masur, Raising the Stakes in Patent Cases, 101 GeO. L.J. 637, 640-41 (2013) ("The PTO issues scores of invalid patents every year. ..."); Beth Simone Noveck, "Peer to Patent": Collective Intelligence, Open Review, and Patent Reform, 20 HARV. J.L. \& TECH. 123, 123 (2006) ("There is a crisis of patent quality. Patents are being issued that are vague and overbroad, lack novelty, and fail the constitutional mandate '[t]o promote the progress of Science and useful Arts."); Wagner, supra note 205, at 2136 ("[T] he need to improve patent quality is essentially undisputed.").

208. See John A. Allison \& Mark A. Lemley, Empirical Evidence on the Validity of Litigated Patents, 26 AIPLA Q.J. 185, 205 (1998) (illustrating the ratios of valid and invalid litigated patents). This figure excludes settled cases, which could involve a greater frequency of valid patents. Id. Other older studies also have found high rates of invalidity. See, e.g., Kimberley A. Moore, Judges, Juries, and Patent Cases-An Empirical Peek Inside the Black Box, 99 Mich. L. REV. 365, 392 (2000) (noting that judges upheld validity of patents in only sixty-four percent of cases during the period 1983-1999). An unpublished 2012 study found much higher invalidity rates. This study examined 283 cases where patent validity was determined by a federal district court during the period from 2007 to 2011 . It concluded that cases in which claims in a patent were held valid decreased from twenty percent in 2007 to six percent in 2011, and averaged only fourteen percent during the study period. Morgan, Lewis \& Bockius, United States Patent InValidity Study 2012, at 2, available at https://www.morganlewis.com/pubs/Smyth_USPatentInvalidity_Sept12.pdf. The same study also found that when the district court invalidated a patent, the Federal 
is a function of multiple factors. One such factor is time - patent examiners average a mere eighteen hours per patent application ${ }^{209}$ and this short window has undermined the PTO's ability to provide adequate examinations. ${ }^{210}$ A second factor is money. Some recent evidence suggests that the PTO, whose "budget is largely derived from patent examination and post-allowance fees," ${ }^{211}$ is biased toward granting patents. Specifically, the PTO preferentially grants "patents on technologies with high renewal rates and patent applications filed by large entities," because such patents generate the most revenue. ${ }^{212}$

A third critical factor is the scope of disclosure to the PTO. Rule 56 underscores this point: "[T] he most effective patent examination occurs when ... the [PTO] is aware of and evaluates the teachings of all information material to patentability." 213 Pre-Therasense, the inequitable conduct doctrine addressed the patent-quality problem by increasing the flow of information to examiners. ${ }^{214}$ Post-Therasense, with the incentive for candor diminished by the Federal Circuit and the corresponding proposed revision of Rule 56, the PTO will become even more poorly informed about inventions and relevant art than it is already. ${ }^{215}$ This will undoubtedly have negative consequences, as it cannot help but to further erode patent quality. Society benefits when the PTO grants high-quality patents and suffers when it grants low-quality patents. The issuance of valid patents creates incentives for innovation and promotes the commercialization of beneficial technical advances, ${ }^{216}$ whereas bad patents

Circuit affirmed that decision in more than 70 percent of the cases during the period 20022012. Id. at 8.

209. Mark A. Lemley, Rational Ignorance at the Patent Office, 95 Nw. U. L. REv. 1495, 1500 (2001).

210. See Doug Lichtman \& Mark Lemley, Rethinking Patent Law's Presumption of Validity, 60 STAN. L. REv. 45, 46-47 (2007) (noting that resource and time constraints hinder accurate evaluation of patents).

211. Michael D. Frakes \& Melissa F. Wasserman, Does Agency Funding Affect Decisionmaking?: An Empirical Assessment of the PTO's Granting Patterns, 66 VAND. L. REV. 67, 69 (2013).

212. Id. at 70 .

213. 37 C.F.R. $\S 1.56$ (a) (2009). Numerous courts and commentators agree. See, e.g., Avocent Redmond Corp. v. Raritan Americas, Inc., 921 F. Supp. 2d 229, 242 (S.D.N.Y. 2013) ("The public interest is best served when the USPTO is aware of all information material to patentability."); Seymour, supra note 205, at 1039 ("The quality of an issued patent depends on the quality of the underlying Patent Office examination. To a large extent the assurance of a good Patent Office examination is all about information.").

214. See Cotropia, supra note 60 , at 755 (noting that historically, the inequitable conduct doctrine helped address the patent quality problem).

215. Rantanen \& Petherbridge, supra note 79, at 242 (concluding that the PTO "will be even more in the dark when conducting patent examinations after Therasense than it was before").

216. See, e.g., Mark A. Lemley, Ex Ante versus Ex Post Justifications for Intellectual 
(with their presumption of validity) tend to block innovation.

As will be shown below, the adoption of the AIA has served to exacerbate the foregoing negative effects of the Therasense decision. The combination of Therasense and AIA has substantially limited the use of the inequitable conduct defense. There has been a significant reduction in both the assertion of the defense ${ }^{217}$ and the success of the defense. In the first year after Therasense was decided, federal district courts granted eleven motions for summary judgment seeking a finding of no inequitable conduct, while denying only three such motions. ${ }^{218}$ In the same time period federal district courts issued thirteen post-trial opinions finding no inequitable conduct and only three opinions finding such conduct. ${ }^{219}$ More recently, district court dismissals of inequitable conduct claims have continued to rise. ${ }^{220}$

\section{E. Walker Process Antitrust Claims}

Beyond its negative impact on the use of the inequitable conduct defense, Therasense also will significantly limit the opportunity for alleged

Property, 71 U. CHI. L. REv. 129, 129-30 (2004) (stating that one justification for intellectual property rights is to incentivize the creation of new ideas by protecting such ideas from being copied freely).

217. See Ryan Davis, Inequitable Conduct a Dying Defense 2 Years Post-Therasense, LAw360 (May 23, 2013, 9:13 PM) available at http://www.law360.com/articles/444480/inequitable-conduct-a-dying-defense-2-years-posttherasense ("Proving an inequitable conduct defense in a patent case has become so difficult because of the Federal Circuit's Therasense ruling that attorneys rarely bother to mount it anymore ....”); Daniel J. Schwartz, Leveraging Strategies and Scheduling Complexities in Patent Cases to Design Successful Infringement Defenses, 2013 WL 574400, at *5 (Aspatore, 2013) (noting that post-Therasense "there have been far fewer inequitable conduct decisions"); Oelke, supra note 96 , at *5 (noting that the inequitable conduct defense is pled less frequently "given that the defense is far less likely to prevail following Therasense").

218. Carlson, supra note 69, at 17.

219. Id.; see also White, supra note 3, at 717 (observing that combination of Therasense and AIA "effectively eliminated" the inequitable conduct doctrine); Cheng, Isackson \& Gray, supra note 147 (noting the scarcity of post-Therasense cases finding inequitable conduct). For a rare example of a post-Therasense court granting a motion for summary judgment of unenforceability due to inequitable conduct, see Caron v. QuicKutz, Inc., No. CV-09-02600-PHX-NVW, 2012 WL 5497869, at*14 (D. Ariz. Nov. 13, 2012) (holding that submission of unmistakably false affidavit constituted an affirmative act of egregious misconduct).

220. See David A. Kelly, The Impact of the America Invents Act and Recent Court Decisions on Patent Law Practitioners and Their Clients, 2012 WL 6636449, at *11 (Aspatore, Nov. 2012) (stating that district courts increasingly dismiss inequitable conduct claims); Bruce Wexler \& Jamie Lucia, IP: Inequitable Conduct Post-Therasense, INSIDECOUNSEL (Aug. 13, 2013) http://www.insidecounsel.com/2013/08/13/ip-inequitableconduct-post-emtherasense-em (noting that district courts "have increasingly been willing ... to dismiss or strike inequitable conduct defenses at the pleadings stage"). 
patent infringers to assert Walker Process antitrust claims. A patent is a monopoly by nature ${ }^{221}$ but a patent-holder can generally enforce its rights under an unexpired patent without fear of antitrust liability under an exception to antitrust law. ${ }^{222}$ However, the Supreme Court held in Walker Process Equipment, Inc. v. Food Machinery \& Chemical Corp. ${ }^{223}$ that if a patent-holder obtained its patent by knowingly and willfully misrepresenting facts to the PTO, such behavior may be sufficient to strip it of its exemption from antitrust laws. ${ }^{224}$ In its decision, the Supreme Court cited the same early unclean hands cases that are the foundation of inequitable conduct law - Keystone, Hazel-Atlas, and Precision. ${ }^{225}$

Walker Process claims are increasingly common. ${ }^{226}$ Such claims, which have been described as more egregious versions of inequitable conduct, ${ }^{227}$ are typically asserted as counterclaims by defendants in patent

221. See Zenith Radio Corp. v. Hazeltine Research, Inc., 395 U.S, 100, 135 (1969) (referring to patent as a "legal monopoly"); Sears, Roebuck \& Co. v. Stiffel Co., 376 U.S. 225, 229 (1964) ("The grant of a patent is the grant of a statutory monopoly.").

222. See Precision Instrument Mfg. Co. v. Auto. Maint. Mach. Co., 324 U.S. 806, 816 (1945) ("[A] patent is an exception to the general rule against monopolies and to the right to access to a free and open market."); accord Fed. Trade Comm'n v. Actavis, Inc., 133 S. Ct. 2223, 2238 (2013) (Roberts, C.J., dissenting) (stating that a patent is an exception to antitrust law).

223. 382 U.S. 172 (1965). Subsequent case law permits the plaintiff to make an alternative showing - that, whether or not the patent-holder obtained the patent by fraud, the infringement suit was a mere sham to cover what is nothing more than an attempt to interfere directly with the business relationships of a competitor. See Nobelpharma AB v. Implant Innovations, Inc., 141 F.3d 1059, 1071 (Fed. Cir. 1998) (stating that such a sham deprives a party of immunity from antitrust laws). This alternative showing is a separate theory of relief that, although sometimes conflated with Walker Process fraud, is governed by different standards. Under Professional Real Estate Investors, Inv. v. Columbia Pictures Indus., Inc., 508 U.S. 49, 60-61 (1993) (internal quotations omitted), a party asserting a claim of sham litigation must show that (1) the lawsuit is objectively meritless such that no reasonable litigant could expect success on the merits, and (2) the baseless lawsuit "conceals an attempt to interfere directly with the business relationships of a competitor." In patent litigation, a sham suit (sometimes referred to as a "PRE claim") must be subjectively brought in bad faith and based on a theory of infringement or invalidity that is objectively baseless. See Cornucopia Prods., LLC v. Dyson, Inc., 881 F. Supp. 2d 1086, 1103 (D. Ariz. 2012) (dismissing PRE claim); TransWeb LLC v. 3M Innovative Prop. Co., No. 10-4413 (FSH), 2011 WL 2181189, at *15 (D.N.J. June 1, 2011) (explaining elements of sham litigation claim); see also Nobelpharma, 141 F.3d at 1071 (noting that PRE and Walker Process provide alternative legal theories on which a patentee may lose its antitrust immunity, and both theories may be applied to the same conduct); S.W. O'Donnell, Unified Theory of Antitrust Counterclaims in Patent Litigation, 9 VA. J.L. \& TECH. 1, 3 n.8 (2004) (observing that, prior to Nobelpharma, the Federal Circuit was "on a path of congruence" between Walker Process and PRE).

224. Walker Process, 382 U.S. at 177.

225. Id.

226. See Oelke, supra note 96 at *8-9 (observing a recent uptick in the litigation of hybrid cases that assert a mixture of patent and Walker Process claims).

227. See SanDisk Corp. v. STMicroelectronics, Inc., No. C 04-4379 JF (RS), 2008 WL 
infringement suits. ${ }^{228}$ Under Federal Circuit law, direct purchasers of patented products also have standing to bring Walker Process claims, even if they lack standing to bring declaratory judgment actions to invalidate the patents. ${ }^{229}$ In order to succeed, the complaining party must show the patent-holder both (1) procured its patent by knowingly and willfully misrepresenting facts to the PTO or (in the case of an assignee) maintained and enforced the patent with knowledge of the fraudulent manner in which it was procured, and (2) monopolized or attempted to monopolize the relevant market, in violation of the Sherman Act. ${ }^{230}$ If the party can make both showings, it can establish antitrust liability and obtain treble damages under section four of the Clayton Act, ${ }^{231}$ equitable relief under section 16 of

4615605, at *5 n.5 (N.D. Cal. Oct. 17, 2008) ("Walker Process fraud essentially is a more egregious version of inequitable conduct."); cf. Nobelpharma, 141 F.3d at 1069 (noting that inequitable conduct is "a broader, more inclusive concept than the common law fraud needed to support a Walker Process counterclaim").

228. See Nobelpharma, 141 F.3d at 1067 (alleged infringer counterclaimed, asserting antitrust violation); Cornucopia Prods., 881 F. Supp. 2d at 1098 (permitting limited offensive use of Walker Process claim where it was substantively indistinguishable from a typical Walker Process counterclaim); Kroger Co. v. Sanofi-Aventis, 701 F. Supp. 2d 938, 960 (S.D. Ohio 2010) ("Typically, Walker Process claims are brought as counterclaims in patent infringement lawsuits ....”).

229. See Ritz Camera \& Image, LLC v. SanDisk Corp., 700 F.3d 503, 508 (Fed. Cir. 2012). Ritz Camera, decided in late 2012, arguably expands the universe of potential Walker Process claims, because patent holders can now be sued by a wide range of parties who allege that they paid inflated prices for goods protected by patents. However, the high bar to proving fraud before the PTO minimizes the long-term impact of the case. Indeed, in Ritz Camera the Federal Circuit specifically rejected the argument that its holding would trigger a flood of litigation and stem innovation, especially given the demanding proof requirements of a Walker Process claim. Id. The Federal Circuit noted that the Supreme Court had rejected the same flooding argument in Walker Process. Id.

230. Walker Process, 382 U.S. at 174, 176-77. The first prong makes clear that invalidity of the patent is insufficient and a showing of intentional fraud in its procurement is required. The second prong incorporates the rules of antitrust law generally. Ritz Camera \& Image, LLC, 700 F.3d at 506. The Sherman Act provides, in relevant part, that "[e]very person who shall monopolize, or attempt to monopolize, or combine or conspire with any other person or persons, to monopolize any part of the trade or commerce among the several States, or with foreign nations, shall be deemed guilty of a felony ...."15 U.S.C. $\S 2$ (2006). A monopolization claim has two elements: "(1) the possession of monopoly power in the relevant market and (2) the willful acquisition or maintenance of that power, as distinguished from growth or development as a consequence of a superior product, business acumen, or historic accident." United States v. Grinnell Corp., 384 U.S. 563, 570-71 (1966). "The relevant market is the field in which meaningful competition is said to exist." IGT v. Alliance Gaming Corp., 702 F.3d 1338, 1344 (Fed. Cir. 2012) (quoting Image Technical Servs., Inc. v. Eastman Kodak Co., 125 F.3d 1195, 1202 (9th Cir. 1997)). Numerous Walker Process claims fail due to the plaintiff's failure to identify a pertinent market or demonstrate the other party's market power. Christopher R. Leslie, Antitrust, Inequitable Conduct, and the Intent to Deceive the Patent Office, 1 UC IRvINE L. REv. 323, 344 (2011).

231. 15 U.S.C. $§ 15(2006)$. 
the Clayton Act, or both. ${ }^{232}$ Whether conduct in procuring or enforcing a patent suffices to strip a patentee of its immunity from antitrust laws is decided under Federal Circuit law, whereas regional circuit law applies to the other elements of antitrust law (for example, market power). ${ }^{233}$ State antitrust law frequently closely tracks the language of the Sherman Act, so antitrust claims asserted under state statutes in patent infringement cases are typically analyzed under the same rules and case law applicable to Sherman Act claims. ${ }^{234}$ At least one federal court has held that plaintiffs may assert state law Walker Process-type antitrust claims predicated on fraudulent conduct before the PTO. ${ }^{235}$

Walker Process fraud must be pled with particularity under Rule 9(b). ${ }^{236}$ To plead and prove the first prong (fraud on the PTO), a party asserting a Walker Process claim must establish each of the following elements: (1) the patentee obtained a patent by knowingly and willfully misrepresenting material facts to the PTO (or omitting to state material facts), (2) the patentee acted with intent to deceive the PTO, (3) the PTO justifiably relied on the misrepresentation or omission, and (4) the patent would not have issued but for the misrepresentation or omission. ${ }^{237}$

A primary difference between inequitable conduct claims and Walker Process claims is temporal. Whereas inequitable conduct generally

232. Walker Process, 382 U.S. at 177-78; 15 U.S.C. $§ 26$ (2006). In Southern Snow Mfg. Co. v. SnoWizard Holdings, Inc., Civil Action Nos. 06-9170, 09-3394, 10-0791, 11 1499, 2013 WL 620266, at*4-5 (E.D. La. Feb. 19, 2013), a federal district court extended Walker Process and held that the attempted enforcement of a trademark registration obtained by fraud can constitute an antitrust violation.

233. Nobelpharma AB v. Implant Innovations, Inc., 141 F.3d 1059, 1068 (Fed. Cir. 1998); Cornucopia Prods., LLC v. Dyson, Inc., 881 F. Supp. 2d 1086, 1098 (D. Ariz. 2012) ("Federal Circuit law now governs the patent-specific portions of [a Walker Process] claim, while regional circuit law governs the antitrust-specific portion of the claim."). See also In re Lipitor Antitrust Litig., MDL No. 2332, Master Docket No. 3:12-cv-2389 (PGS), 2013 U.S. Dist. LEXIS 126468, at*65 (D.N.J. Sept. 5, 2013) (noting that that Ritz Camera is persuasive authority, but not binding on the federal district court).

234. See, e.g., TransWeb LLC v. 3M Innovative Prop. Co., Civil Action No. 10-4413 (FSH), 2011 WL 2181189, at *12 (D.N.J. June 1, 2011) ("Because New Jersey's antitrust statutes are construed in harmony with federal antitrust statutes, the Court need not separately analyze the state law claims."); Kimberley-Clark Worldwide, Inc. v. First Quality Baby Prods., LLC, Civil No. 1:CV-09-1685, 2011 WL 1883815, at*2 n.1 (M.D. Pa. May 17, 2011) (noting that requirements under New York's Donnelly Act are identical to a monopolization claim under the Sherman Act); Correct Craft IP Holdings, LLC v. Malibu Boats, LLC, No. 6:09-cv-813-Orl-28KRS, 2010 WL 598693, at*8 (M.D. Fla. Feb. 17, 2010) (noting that Florida Antitrust Statutes "closely track the language of the Sherman Act and are analyzed under the same rules and case law").

235. In re DDAVP Indirect Purchaser Antitrust Litig., 903 F. Supp. 2d 198, 215-19 (S.D.N.Y. 2012).

236. TransWeb, 2011 WL 2181189 at $* 12$.

237. C.R. Bard, Inc. v. M3 Sys., Inc., 157 F.3d 1340, 1364 (Fed. Cir. 1998); accord Nobelpharma, 141 F.3d at 1069-70 (applying the same four-factor test). 
concerns conduct and scienter during the patent prosecution process, Walker Process refers to these elements at the time a patent infringement action is commenced, which may occur many years after a patent issues. ${ }^{238}$

A more important distinction concerns proof. Prior to Therasense a party seeking to establish Walker Process fraud confronted a more onerous burden than a party seeking to establish inequitable conduct, insofar as Walker Process fraud required a higher showing of both intent and materiality. ${ }^{239}$ Under Walker Process, there must be clear and convincing evidence of intent to deceive the examiner and thereby cause the PTO to issue an invalid patent. ${ }^{240}$ With respect to fraudulent omissions, there must be evidence of intent separable from the simple fact of the omission. ${ }^{241}$ The intent prong, which apparently requires specific intent, ${ }^{242}$ is difficult to prove, so the common result is summary judgment in favor of Walker Process defendants. ${ }^{243}$ Walker Process fraud also requires but-for materiality, ${ }^{244}$ whereas inequitable conduct pre-Therasense did not. Finally, use of a sliding scale to balance materiality and intent was authorized by the Federal Circuit pre-Therasense in inequitable conduct cases, ${ }^{245}$ whereas no such scale has been approved for use in Walker

238. Herbert Hovenkamp, Competition for Innovation, 2012 ColuM. Bus. L. Rev. 799, 828.

239. Dippin' Dots, Inc. v. Mosey, 476 F.3d 1337, 1346 (Fed. Cir. 2007) ("To demonstrate Walker Process fraud, a claimant must make higher threshold showings of both materiality and intent than are required to show inequitable conduct."); SanDisk Corp. v. STMicroelectronics, Inc., No. C 04-4379 JF (RS), 2008 WL 4615605, at*7 n.8 (N.D. Cal. Oct. 17, 2008) (commenting that the scienter requirement for inequitable conduct is "much lower" than for Walker Process fraud); Oelke, supra note 96 at *9 (noting the significant difference pre-Therasense between the levels of materiality and intent required to prove inequitable conduct and Walker Process fraud).

240. Nobelpharma, 141 F.3d at 1070; Cornucopia Prods., LLC v. Dyson, Inc., 881 F. Supp. 2d 1086, 1099 (D. Ariz. 2012).

241. Dippin' Dots, Inc., 476 F.3d at 1347.

242. See American Hoist \& Derrick Co. v. Sowa \& Sons, Inc., 725 F.2d 1350, 1368 (Fed. Cir. 1984) (stating that in a Walker Process claim based on attempt to monopolize, "a specific intent, greater than an intent evidenced by gross negligence or recklessness, is an indispensable element"); accord Argus Chem. Corp. v. Fibre Glass-Evercoat Co., 812 F.2d 1381, 1385 (Fed. Cir. 1987) (quoting American Hoist's requirement of specific intent). But cf. Hydril Co. LP v. Grant Prideco LP, 474 F.3d 1344, 1349 (Fed. Cir. 2007) (explaining that Walker Process fraud requires "the intent to deceive or, at least, a state of mind so reckless as to the consequences that it is held to be the equivalent of intent (scienter)").

243. SanDisk Corp., 2008 WL 4615605 at *7 ("This intent requirement is a high bar that often results in adjudication in favor of the Walker Process defendant at summary judgment.").

244. Dippin' Dots, 476 F.3d at 1347; accord Nobelpharma, 141 F.3d at 1071 (holding that a party making a Walker Process claim must make "a clear showing of reliance, i.e., that the patent would not have issued but for the misrepresentation or omission"); SanDisk Corp., 2008 WL 4615605, at *5 (noting that materiality requires a showing that the patent would not have been issued but for the misrepresentation).

245. See, e.g., American Hoist \& Derrick Co. v. Sowa \& Sons, Inc., 725 F.2d at 1363 


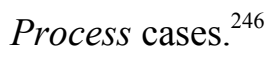

The differing burdens meant that pre-Therasense, a finding of inequitable conduct did not by itself suffice to support a finding of Walker Process fraud, ${ }^{247}$ and, conversely, a finding that the patentee did not engage in inequitable conduct mooted a Walker Process claim. ${ }^{248}$ In short, Walker Process fraud could not be found in the absence of inequitable conduct. ${ }^{249}$ The Federal Circuit has explained the proposition this way: parties in patent infringement litigation seeking unenforceability on the ground of inequitable conduct raise a shield, parties seeking antitrust damages raise a sword, ${ }^{250}$ and parties break their Walker Process swords when they fail to first establish inequitable conduct. ${ }^{251}$

(noting that materiality and culpability are often intertwined; thus, a stronger showing of one may require less of a showing of the other); see also Digital Equip. Corp. v. Diamond, 653 F.2d 701, 716 (1st Cir. 1981) (recognizing that materiality and culpability are intertwined).

246. Nobelpharma, 141 F.3d at 1071.

247. Id. at 1070-71; In re Wellbutrin SR Antitrust Litig., Nos. 04-5525, 05-396, 2010 WL 8425187, at *8 (E.D. Pa. Mar. 31, 2010) ("A showing of inequitable conduct is therefore insufficient to proceed with a Walker Process fraud claim.").

248. See, e.g., In re Lipitor Antitrust Litig., MDL No. 2332, No. 3:12-cv-2389 (PGS), 2013 WL 4780496, at *19-20 (D.N.J. Sept. 5, 2013) (dismissing Walker Process claims based on prior finding of no inequitable conduct in underlying patent case); SanDisk Corp. v. STMicroelectronics, Inc., No. C 04-4379 ZJF (RS), 2009 WL 1404689, at *2 (N.D. Cal. May 19, 2009) ("[J]ust as a finding of inequitable conduct may moot SanDisk's patent infringement claim, a finding that SanDisk did not engage in equitable conduct may moot ST's Walker Process claim ....") (emphasis in original); Hewlett-Packard Co. v. Genrad, Inc., 882 F. Supp. 1141, 1157 (D. Mass. 1995) ("A failure to prove inequitable conduct may eliminate the need to determine the [Walker Process] antitrust counterclaim.").

249. See Metris U.S.A., Inc. v. Faro Tech., Inc., 882 F. Supp. 2d 160, 174 (D. Mass. 2011) ("[A] finding of inequitable conduct [is] a prerequisite for a showing of Walker Process fraud."); Avery Dennison Corp. v. Continental Datalabel, Inc., No. 10 C 2744, 2010 WL 4932666, at * 4 (N.D. Ill. Nov. 30, 2010) ("[A] party that fails to prove inequitable conduct cannot establish a Walker Process violation that is premised on such conduct."); Daiichi Sankyo, Inc. v. Apotex, Inc., No. 030937 (SDW-MCA), 2009 WL 1437815, at *6 (D.N.J. May 19, 2009) ("If a finding of inequitable conduct may be insufficient to meet the more rigorous standard for Walker Process fraud, it logically follows that Walker Process fraud cannot be found in the absence of inequitable conduct."); FMC Corp. v. Manitowac Co., 835 F.2d 1411, 1417 (Fed. Cir. 1987) ("[A] failure to establish inequitable conduct precludes a determination that [plaintiff] had borne its greater burden of establishing the fraud required to support its Walker Process claim."); see also Leslie, supra note 230, at 336 (noting that the Federal Circuit "makes it impossible to prove Walker Process fraud in the absence of inequitable conduct").

250. See Nobelpharma, 141 F.3d at 1070 ("Inequitable conduct is thus an equitable defense in a patent infringement action and serves as a shield, while a more serious finding of fraud potentially exposes a patentee to antitrust liability and thus serves as a sword."); Korody-Colyer Corp. v. Gen. Motors Corp., 828 F.2d 1572, 1578 (Fed. Cir. 1987) (stating that in raising a claim of inequitable conduct, "a party raises a shield," while in contrast, a party asserting Walker Process claims "unsheaths a sword").

251. See FMC Corp., 835 F.2d at 1418 (concluding that when FMC failed to establish inequitable conduct, it "broke its Walker Process sword"). 
Given the opportunity to moot antitrust claims, courts often conclude that the goals of convenience, efficiency, judicial economy, and the avoidance of juror confusion are best served by bifurcating under Rule 42(b) of the Federal Rules of Civil Procedure ${ }^{252}$ and deciding the inequitable conduct defense first, before the antitrust claim is presented to a jury. ${ }^{253}$ The Federal Circuit has described the bifurcation for trial of patent issues and Walker Process issues as "now-standard practice." 254 Bifurcation has also occurred at the discovery stage, ${ }^{255}$ in recognition of the substantial expense and burden associated with discovery in antitrust cases. $^{256}$

252. See FED. R. Civ. P. 42(b) (permitting a court to order separate trials "[f]or convenience, to avoid prejudice, or to expedite and economize.").

253. See, e.g., Seiko Epson Corp. v. E-Babylon, Inc., No. 3:07-CV-896-BR, 2011 WL 5554447 , at $* 2$ n. 3 (D. Or. Nov. 15, 2011) (noting that the court previously stayed and bifurcated antitrust aspects of Walker Process claim pending resolution of inequitable conduct claim); Seiko Epson Corp. v. Glory S. Software Mfg., Inc., No. 06-CV-477-BR, 2010 WL 256505, at $* 5$ (D. Or. Jan. 19, 2010) (bifurcating and staying trial of Walker Process claim in interest of efficiency); SanDisk Corp. v. STMicroelectronics, Inc., No. C 04-4379 ZJF (RS), 2009 WL 1404689, at *2 (N.D. Cal. May 19, 2009) ("[A] finding that SanDisk did not engage in inequitable conduct may moot ST's Walker Process claim .... Accordingly, the Court concludes that convenience and judicial economy would be best served by trying the inequitable conduct defense first.") (emphasis in original); Squared D Co. v. E.I. Elec., No. 06 C 5079, 2009 WL 136177, at *2-3 (N.D. Ill. Jan. 15, 2009) (bifurcating inequitable conduct and Walker Process claims); Hewlett-Packard Co. v. Genrad, Inc., 882 F. Supp. 1141, 1157 (D. Mass. 1995) ("[C]ourts often separate patent issues from antitrust counterclaim issues.").

254. See In re Innotron Diagnostics, 800 F.2d 1077, 1084 (Fed. Cir. 1986) (discussing 23 cases utilizing the "now-standard practice" of bifurcating patent and antitrust issues); accord U.S. Gypsum Co. v. Nat'l Gypsum Co., No. 89 C 7533, 1994 WL 74989, at *2 (N.D. Ill. Mar. 10, 1994) (noting "common practice" to bifurcate patent infringement and antitrust issues).

255. See, e.g., Square D Co., 2009 WL 136177 at *2 (stating that bifurcation of issues can reduce the enormous expenses associated with discovery in antitrust cases); ChipMender, Inc. v. Sherwin Williams Co., No. C 05-3465 PJH, 2006 WL 13058, at*13 (N.D. Cal. Jan. 3, 2006) (concluding that potential prejudice and other relevant factors necessitate the bifurcation of issues and stay of discovery); Implant Innovations, Inc. v. Nobelpharma AB, No. 93 C 7489, 1996 WL 568791, at *3 (N.D. Ill. Oct. 2, 1996) (determining that antitrust claims should be tried separately from patent claims in light of the great expense involved in antitrust discovery).

256. See DSM Desotech Inc. v. 3D Systems, Inc., No. 08 CV 1531, 2008 WL 4812440, at *2 (N.D. Ill. Oct. 28, 2008) ("[D]iscovery in any antitrust case can quickly become enormously expensive and burdensome to defendants.") (emphasis in original); Roy W. Breitenbach \& Alicia M. Wilson, Managing the Fact Discovery Tsunami: Tips When Defending a Federal Antitrust Case, N.Y.L.J., Jan. 18, 2011, at S8 ("In complex antitrust disputes, the amount of [electronically-stored information] often is so vast, and the preservation and production issues so complex, that e-discovery issues quickly spin out of control and destroy the entire defense budget."); William H. Wagener, Note, Modeling the Effect of One-Way Fee Shifting on Discovery Abuse in Private Antitrust Litigation, 78 N.Y.U. L. REV. 1887, 1898-99 (2003) ("[C]ourts typically permit antitrust discovery to range further (and costs to run higher) than in most other cases.”). But cf. Mark Anderson \& 
In Therasense the Federal Circuit did not signal that the components of Walker Process fraud have changed. ${ }^{257}$ None of the opinions in the en banc decision even considers the implications of the decision for Walker Process litigation. But the court's dramatic revision in Therasense of the standard for proving inequitable conduct has realigned the doctrine to make it "virtually congruent with intentional fraud under Walker Process." 258 This realignment has major implications for Walker Process claims. Even prior to Therasense, successful Walker Process claims were "few and far between," ${ }^{, 259}$ with many such claims being dismissed on summary judgment motions. ${ }^{260}$ Successful antitrust claims post-Therasense will be even rarer. As noted, Walker Process claims cannot proceed in the absence of inequitable conduct. Because the combination of Exergen and Therasense has made it so difficult to plead and prove inequitable conduct, many defendants who in the past might have been able to prosecute Walker Process claims will be barred from doing so even though inequitable

Max Huffman, Iqbal, Twombly, and the Expected Cost of False Positive Error, 20 CORNELL J.L. \& PUB. POL'Y 1, 18 \& n.84 (2010) (noting that a quantitative analysis of discovery expense in antitrust suits "does not appear to exist in current literature").

257. TransWeb LLC v. 3M Innovative Prop. Co., No. 10-4413 (FSH), 2011 WL 2181189 , at *12 (D.N.J. June 1, 2011) (stating that the Federal Circuit in Therasense failed to indicate that elements of Walker Process claims had changed in light of its decision).

258. J. Thomas Rosch, Patent Law and Antitrust Law: Neither Friend nor Foe, but Business Partners, 13 Sedona Conf. J. 95, 100 (2012); accord Metris U.S.A., Inc. v. Faro Tech., Inc., No. 08-CV-11187-PBS, 2011 WL 4346852, at*1 (D. Mass. Sept. 19, 2011) ("[I]t appears that Walker Process fraud is now largely coextensive with the new inequitable conduct doctrine."). One respect in which the doctrines are not entirely congruent concerns the adoption in Therasense of the egregious misconduct exception to but-for materiality. See Leslie, supra note 230, at 344 ("Although Therasense has narrowed the definition of materiality for inequitable conduct, the definition remains broader than materiality for Walker Process purposes. Walker Process uses true but-for materiality, while Therasense adopted what may be termed 'but-for plus' since 'affirmative egregious misconduct' can be material even if the patent would have otherwise issued.") (internal citations omitted).

259. Rosch, supra note 258, at 99; see also David R. Steinman \& Danielle S. Fitzpatrick, Antitrust Counterclaims in Patent Infringement Cases: A Guide to Walker Process and Sham-Litigation Claims, 10 TEX. InTELL. Prop. L.J. 95, 99 (2001) (calling Walker Process claims "extremely unsuccessful"). Rare examples of evidence sufficient to show Walker Process fraud include (1) deleting references to on-point prior art from a patent application with no adequate explanation, Nobelpharma AB v. Implant Innovations, Inc., 141 F.3d 1059, 1062, 1072 (Fed. Cir. 1989); (2) failing to include prior art known to the patent applicant through multiple personal demonstrations of that art, Unitherm Food Sys., Inc. v. Swift-Eckrich, Inc., 375 F.3d 1341, 1360-61 (Fed. Cir. 2004), rev'd on other grounds, 546 U.S. 394 (2006); and (3) failing to include a full translation of a foreign patent where that patent was the only document in the initial application that, if fully understood by the patent examiner, would have resulted in a denial of the application. Kaiser Found. Health Plan, Inc. v. Abbott Labs, Inc., 552 F.3d 1033, 1051 (9th Cir. 2009).

260. Paul D. Swanson, The Patent Legal Malpractice Implications of 'Walker Process' Antitrust Claims, Patent Practice Prof'L Liab. ReP. (Mar. 5, 2013), available at http://www.jdsupra.com/legalnews/the-patent-legal-malpractice-implication-94471/. 
conduct claims are more likely to provide a sound basis for Walker Process claims than ever before. ${ }^{261}$ The Walker Process standard has not changed, but the hurdles for advancing to the antitrust phase of bifurcated patent litigation have been raised even higher. ${ }^{262}$

The expected reduction in Walker Process litigation is likely to further reduce the incentive for patent applicants to make full disclosure to the PTO and may invite fraud. The minimized prospect of facing an award of treble damages under the Clayton Act may encourage applicant fraud by rendering misconduct before the PTO cost-beneficial. ${ }^{263}$

The virtual alignment of inequitable conduct and Walker Process fraud that was accomplished by Therasense also increases the likelihood that the Seventh Amendment ${ }^{264}$ right of Walker Process claimants to have their antitrust claims tried by a jury will be infringed. Parties asserting antitrust claims have an undisputed right to a jury trial, ${ }^{265}$ but parties asserting a defense or affirmative claim of inequitable conduct have no Seventh Amendment right, because the latter assertions seek relief pursuant to the court's equitable powers. ${ }^{266}$ Complications arise when bifurcation occurs. Rule 42(b) expressly instructs that a court considering bifurcation

261. See Rantanen \& Petherbridge, supra note 79, at 250 (describing the requirements for establishing inequitable conduct and Walker Process fraud).

262. Cf. Herbert J. Hovenkamp, Patent Exclusions and Antitrust After Therasense 29 (Univ. of Iowa Legal Stud. Res. Paper No. 11-39, Dec. 2011), available at http://ssrn.com/abstract=1916074 (arguing that Walker Process actions should be permitted to proceed where there is no inequitable conduct as Therasense defines it, but evidence of prior art later emerges).

263. Stijepko Tokic, Enforcing the Duty of Disclosure after Therasense: Antitrust Implications, 40 AIPLA Q.J. 221, 258 (2012) (arguing that Therasense seriously reduces the likelihood of a consumer antitrust action and recovery because of a significantly higher burden of proving inequitable conduct).

264. The Seventh Amendment to the United States Constitution provides: "In Suits at common law, where the value in controversy shall exceed twenty dollars, the right of trial by jury shall be preserved, and no fact tried by a jury, shall be otherwise re-examined in any Court of the United States, than according to the rules of the common law." U.S. CONST. amend. VII.

265. See Beacon Theaters, Inc. v. Westover, 359 U.S. 500, 504 (1959) ("[T]he right to a trial by jury applies to treble damages under the antitrust laws ....”).

266. See Am. Calcar, Inc. v. Am. Honda Motor Co., 651 F.3d 1318, 1333 (Fed. Cir. 2011) ("Inequitable conduct is equitable in nature, with no right to a jury ...."); Cabinet Vision v. Cabnetware, 129 F.3d 595, 599 n.4 (Fed. Cir. 1997) ("[Appellee Cabnetware's] affirmative defense of inequitable conduct seeks relief by way of the court's equitable powers; it is not a suit at common law and therefore cannot alone entitle the parties to a jury trial.”); Duhn Oil Tool, Inc. v. Cooper Cameron Corp., 818 F. Supp. 2d 1193, 1204 (E.D. Cal. 2011) ("The Seventh Amendment jury trial right does not attach to claims based in equity, such as the defense of inequitable conduct."); T. Leigh Anenson, The Triumph of Equity: Equitable Estoppel in Modern Litigation, 27 REV. OF LITIG. 377, 412-18 (2008) (noting that a plaintiff is entitled to a jury trial "only when there are common issues of fact material to the disposition of both law and equity"). 
must always preserve inviolate the right of trial by jury as declared by the Seventh Amendment to the Constitution or as given by a statute of the United States. ${ }^{267}$ If inequitable conduct and antitrust issues are bifurcated, an initial bench determination that inequitable conduct did not occur may operate to preclude a subsequent jury trial on a Walker Process antitrust claim and thus violate the Seventh Amendment.

Prior to Therasense, at least one federal district court acknowledged the Seventh Amendment issue and refused to bifurcate inequitable conduct and Walker Process claims. ${ }^{268}$ But many other pre-Therasense courts chose to ignore the issue and granted bifurcation requests. ${ }^{269}$ Although it is unclear why the issue was routinely ignored, courts (and litigators) may have assumed that a bench determination that no inequitable conduct occurred necessarily meant that no reasonable jury could find that Walker Process fraud occurred, given the more stringent requirements of the antitrust claim. ${ }^{270}$

The Seventh Amendment issue is likely to loom even larger postTherasense, following the virtual alignment of the standards for proving inequitable conduct and Walker Process fraud. ${ }^{271}$ This realignment makes it increasingly likely that Walker Process claimants will be deprived of trials, because significantly fewer inequitable conduct claims will survive. The court explained in Metris U.S.A., Inc. v. Faro Technology, Inc. ${ }^{272}$ in 2011 that "[i]f a judge's determination of no inequitable conduct precluded a jury from later finding Walker Process fraud as a matter of law, then a viable argument could be made that the doctrines would collide with the protections afforded Walker Process claimants by the Seventh Amendment."273

267. FED. R. Civ. P. 42(b).

268. See Celgene Corp. v. Barr Labs., Inc., No. 07-286 (SDW), 2008 WL 2447354, at *3 (D.N.J. June 13, 2008) (refusing to bifurcate because bifurcation could violate the constitutional right to trial by jury). $C f$. Implant Innovations, Inc. v. Nobelpharma $A B, N o$. $93 \mathrm{C} 7489,1996 \mathrm{WL} 568791$, at *3 (N.D. Ill. Oct. 2, 1996) (concluding that a prior determination by the court of the inequitable conduct aspect of the patent claim would violate the Seventh Amendment, and ordering jury trial for both inequitable conduct and antitrust issues).

269. Asim M. Bhansali \& William S. Hicks, Trial Management after Therasense: Inequitable Conduct, Walker Process Fraud, and the Seventh Amendment, 21 (No. 2) COMPETITION 1, 6 (2012) ("[R] equests to bifurcate and stay Walker Process claims were often granted in the pre-Therasense era without any consideration of Seventh Amendment issues."). Some courts have ordered trifurcation. See, e.g., Hunter Douglas, Inc. v. Comfortex Corp., 44 F. Supp. 2d 145, 155 (N.D.N.Y. 1999).

270. Bhansali \& Hicks, supra note 269, at 21.

271. Id. at 8 (noting that alignment of inequitable conduct and Walker Process standards "has highlighted Seventh Amendment concerns arising from bifurcation that existed even before Therasense").

272. 882 F. Supp. $2 d 160$ (D. Mass. 2011).

273. Id. at 175. See also SanDisk Corp. v. STMicroelectronics, Inc., No. C 04-4379 ZJF 
In summary, Therasense will constrict the availability of the inequitable conduct defense, and the new congruence of the standards for inequitable conduct and Walker Process fraud is likely to simultaneously constrict the availability of the antitrust claim and infringe the Seventh Amendment jury trial rights of Walker Process litigants.

\section{AMERICA INVENTS ACT}

Congress enacted the AIA several months after the Federal Circuit issued its en banc decision in Therasense. The AIA, signed into law on September 16, 2011 and fully in effect in March 2013, is the most significant revision to the U.S. patent regime since the 1952 enactment of the Patent Act, which recodified the entirety of U.S. patent law. ${ }^{274}$ The AIA may be the most significant change to U.S. patent laws since the 1836 Patent Act, which established the modern American system of patent examination.

The AIA was the culmination of efforts to reform the U.S. patent system that had been under way since the early 2000s. The first version of what became the AIA was introduced in June 2005 and subsequent versions were introduced in the following years. ${ }^{275}$ The failure of these early efforts resulted in frequent intervention by the Federal Circuit and Supreme Court to resolve significant patent issues. In addition to Exergen in 2009 and Therasense in 2011, the intervention encompassed the Federal Circuit decision in In re Seagate Technology, LLC in 2007 (raising the standard for finding willful patent infringement), ${ }^{276}$ as well as Supreme Court decisions reformulating the standards for non-obviousness, ${ }^{277}$

(RS), 2009 WL 1404689, at *2 (N.D. Cal. May 19, 2009) ("When a jury decides the Walker Process fraud, the Seventh Amendment constrains a court's determination of inequitable conduct."); Gordon \& Stack, supra note 43, at 91 (2011) ("Therasense may also

bolster the argument that infringement defendants have a constitutional right to a jury trial on factual issues that are common to an inequitable conduct defense and a Walker Process claim .... To the extent that the underlying elements of proof are now identical, Therasense may strengthen the argument ....")

274. See Lee Petherbridge \& Jason Rantanen, In Memoriam Best Mode, 64 StAn. L. REV. ONLINE $125, \quad 125 \quad$ (2012), http://www.stanfordlawreview.org/sites/default/files/online/articles/64-SLRO-125.pdf (describing the AIA as "the most substantial legislative overhaul of patent law and practice in more than half a century."); PricewaterhouseCoopers, 2012 PATENT LiTIGATION STUDY 3 (Sept. 2012), http://www.pwc.com/us/en/forensic-services/publications/2012-patentlitigation-study.jhtml ("Last year marked the most significant change to the US patent system in almost 60 years.").

275. Joe Matal, A Guide to the Legislative History of the America Invents Act: Part I of II, 21 FED. CIR. B.J. 435, 435-512 (2011-12) (describing the development of the LeahySmith America Invents Act).

276. 497 F.3d 1360 (Fed. Cir. 2007) (en banc).

277. KSR Int'l Co. v. Teleflex Inc., 550 U.S. 398, 419-22 (2007) (rejecting Federal 
injunctive relief, ${ }^{278}$ patent exhaustion, ${ }^{279}$ and patent invalidity. ${ }^{280}$

While the AIA does not expressly address inequitable conduct, several of the statute's provisions may operate to significantly restrict use of the defense. These provisions relate to post-issuance review and the best mode of using the invention. Both changes are discussed below, along with their adverse implications for the inequitable conduct defense.

\section{A. Post-Issuance Review}

The first set of AIA provisions affecting inequitable conduct pertains to post-issuance review. These provisions include post-grant review (PGR), inter partes review (IPR), and supplemental examination.

\section{Background}

The proceedings available after the grant of a patent are conducted through the PTO to reconsider issued patents and can result in confirmation, cancellation, withdrawal, or modification of patent claims. Prior to passage of the AIA, the only post-issuance review options were ex parte reexamination (adopted in 1980) ${ }^{281}$ and inter partes reexamination (adopted in 1999). ${ }^{282}$ The former option constituted the first non-judicial proceeding enabling a third party to challenge the validity of a patent. ${ }^{283} E x$ parte reexamination is available for any patent during the period of its enforceability, which is typically the term of the patent plus six years (representing the statute of limitations for bringing an enforcement action). ${ }^{284}$ In both ex parte reexamination and inter partes reexamination the PTO Director could order a reexamination after a requester raised a substantial new question (SNQ) of patentability for any of the claims of the

Circuit's rigid application of obviousness standard).

278. eBay, Inc. v. MercExchange, L.L.C., 547 U.S. 388, 390-94 (2006) (holding that four-factor test traditionally employed by equity courts in deciding whether to award permanent injunctive relief applies in patent litigation).

279. Quanta Computer, Inc. v. LG Elecs., Inc., 553 U.S. 617, 617-38 (2008) (holding that exhaustion doctrine applies to method patents).

280. Microsoft Corp. v. i4i Ltd. Partnership, 131 S. Ct. 2238, 2238-54 (2011) (reinforcing use of clear and convincing standard for proving patent invalidity).

281. Act of Dec. 12, 1980, Pub. L. 96-517, ch. 30, § 302, 94 Stat. 3015 (listing requirements for requesting reexamination).

282. American Inventors Protection Act of 1999, Pub. L. No. 106-113, tit. IV, 113 Stat. 1501A-0552, at sec. 4601 (explaining the inter partes reexamination procedure).

283. Jeffrey P. Kushan, The Fruits of the Convoluted Road to Patent Reform: The New Invalidity Proceedings of the Patent and Trademark Office, 30 YALE L. \& POL'Y REV. 385, 391 (2012).

284. See 37 C.F.R. $§ 1.501$ (a) (2012) (defining the period in which citations of prior art may be filed); 35 U.S.C. $§ 286$ (2012) (setting forth applicable statute of limitations). 
patent for which it sought reexamination. ${ }^{285}$ This amorphous standard borrowed from the reasonable examiner standard used intermittently for many years to determine materiality under Rule $56 .{ }^{286}$ The ambiguity contributed to rubber-stamping of requests. Approximately ninety-two percent of ex parte reexamination requests and ninety-four percent of inter partes reexamination requests were granted through June 2012. ${ }^{287}$ The Director's determination of a SNQ was final and non-appealable. ${ }^{288}$

The two review options have been criticized for multiple reasons. The first is lack of timeliness and resulting uncertainty. Ex parte reexaminations take an average of two years and pre-AIA the average pendency of an inter partes reexamination was more than three years. ${ }^{289} \mathrm{~A}$ second objection is perceived bias. ${ }^{290}$ Patent owners had no right to initiate inter partes examination, whereas both owners and third-parties can request ex parte reexamination. In recent years approximately ninety percent of ex parte reexamination requests were filed by third parties, ${ }^{291}$ but

285. 35 U.S.C. $\S \S 303$ (a) (2012) ("Within three months following the filing of a request for reexamination under the provisions of section 302 of this title, the Director will determine whether a substantial new question of patentability affecting any claim of the patent concerned is raised by the request.").

286. Mark D. Janis, Rethinking Reexamination: Toward a Viable Administrative Revocation System for U.S. Patent Laws, 11 HARV. J.L. \& TeCH. 1, 48 (1997) (discussing the application of the reasonable examiner standard).

287. Ex Parte Reexamination Filing Data - June 30, 2012, U.S. Patent \& TRADEMARK OFFICE 1 (2012), available at assets.sbnation.com/assets/1619547/Ex parte reexam stats.pdf [hereinafter USPTO EX Parte Reexamination Filing Data]; Inter Partes Reexamination Filing Data - June 30, 2012, U.S. PATENT \& TRADEMARK OfFice 1 (2012), available at $\mathrm{http}: / /$ ptolitigationcenter.com/wpcontent/uploads/2010/02/IP_quarterly_report_June_30_2012.pdf [hereinafter USPTO INTER PARTES REEXMINATION FILING DATA].

288. 35 U.S.C. $\S \S 302,312$; Heinl v. Godici, 143 F. Supp. 2d 593, 596-98 (E.D. Va. 2001) (stating that reexamination is an intermediate or preliminary decision, not final agency action, and therefore not ordinarily subject to judicial review).

289. Andrei Iancu \& Ben Haber, Post-Issuance Proceedings in the America Invents Act, 93 J. Pat. \& Trademark OfF. Soc'y 476, 477 (2011). Cf. Harkins, supra note 69, at *6 ("[I]nter partes reexaminations typically took three to five years."); Eric J. Rogers, Ten Years of Inter Partes Patent Reexamination Appeals: An Empirical View, 29 SANTA ClARA COMPUTER \& High TECH. L.J. 305, 352 (2013) (noting that the mean pendency of completed inter partes reexaminations is 4.9 years). Even these statistics are not a true reflection of the average pendency of inter partes reexaminations, because they only include those that were completed.

290. See Kushan, supra note 283, at 391 ("[F]rom its inception, the ex parte reexamination proceeding has been seen as biased in favor of the patent owner."); accord Sherry M. Knowles, Thomas E. Vanderbloemen \& Charles E. Peeler, Inter Partes Patent Reexamination in the United States, 86 J. PAT. \& Trademark Off. Soc'y 611, 612 (2004) (explaining that procedural benefits in reexamination procedures favor the patent owner).

291. Dennis Crouch, A Rush to File Ex Parte Reexaminations and Now a Lull, PATENTLY-O (Nov. 4, 2012, 7:03 PM), http://www.patentlyo.com/patent/2012/11/a-rush-to- 
the requester does not participate in such proceedings unless she is the patentee. The third party's nominal role is limited to presenting a substantial new question of patentability to the PTO for resolution. If reexamination is granted the third-party's involvement terminates. This defect is magnified by the PTO's susceptibility to "well-recognized externalities that favor sustaining patent claims." 292 In addition, until a few years ago it was common practice for the same examiner who originally issued the patent to be assigned to the ex parte reexamination. ${ }^{293}$ Not surprisingly then, during the period from July 1981 through June 2012, all claims were canceled in ex parte reexaminations only eleven percent of the time. $^{294}$ By comparison, during the period from November 1999 to June 2012, all claims were canceled (or disclaimed) in inter partes reexaminations forty-two percent of the time. ${ }^{295}$

Another common criticism is that both options were limited in scope. Inter partes reexamination allowed challenges only on grounds of novelty or non-obviousness, ${ }^{296}$ and in both proceedings only patents and printed publications could be used to contest the patent. ${ }^{297}$ This is a limiting factor

file-ex-parte-reexaminations-and-now-a-lull.html (stating that around ninety percent of ex parte reexamination requests are filed by third-parties); see also Joseph R. Re, "Parallel Prosecution": Effect of Patent Prosecution on Concurrent Litigation, 73 J. PAT. \& TRADEMARK OfF. SOC'Y 965, 967-68 (1991) (noting that patentees initiate some reexaminations, primarily to strengthen and confirm the validity of their own patents prior to commencing enforcement litigation).

292. Jason Rantanen, Lee Petherbridge \& Jay P. Kesan, America Invents, More or Less?, 160 U. PA. L. REV. PENNumBRA 229, 243 (2012), http://www.pennlawreview.com/online/160-U-Pa-L-Rev-PENNumbra-229.pdf. See also Jonathan Masur, Patent Inflation, 121 YALE L.J. 470, 478 (2011) (“[T]he PTO's salary and bonus system is structured in such a way as to incentivize examiners to grant rather than deny patents.").

293. Nancy J. Linck, Bruce H. Stoner, Lee E. Barrett \& Carol A. Spiegel, PostGrant Patent Practice 6 (2012).

294. USPTO Ex PARTE ReEXAmination Filing Data, supra note 287, at 2.

295. USPTO Inter PARTES ReEXAMINATION Filing DATA, supra note 287. This percentage, while high, does not necessarily reveal success by third-party requesters, because the cancellation of patent claims might be irrelevant to infringement accusations against the requester. Rogers, supra note 289, at 347 (explaining that the cancellation and/or amendment of patent claims resulting from the proceeding might be immaterial to accusations of patent infringement raised); see also Linck, STONER, BARRETT \& SPIEGEL, supra note 293, at 7 ("Based on these statistics, one may reasonably conclude that the patent owner fares better in ex parte reexamination than in inter partes reexamination, at least in part due to the lack of third party participation.").

296. Michael A. Carrier, Post-Grant Opposition: A Proposal and a Comparison to the America Invents Act, 45 U.C. DAVIS L. REV. 103, 113-14 (2011) (arguing that one limitation of inter partes reexamination is that it allows challenges only on grounds of novelty or nonobviousness).

297. Kushan, supra note 283, at 392, 394 (explaining that only patents and printed publications, and not other types of evidence, can be used to contest the patent). 
because an argument of invalidity often is based on unprinted prior art. ${ }^{298}$ Finally, inter partes reexaminations were subject to strong estoppel provisions that operated as a major disincentive to utilize the proceedings, especially in conjunction with the inability of a third-party requester to cross-examine the patentee. ${ }^{299}$

The foregoing disadvantages, primarily imposed on third-party challengers, collectively explain the limited use of the proceedings. ${ }^{300}$ Nearly 4,500 patents are issued every week, whereas ex parte reexamination has applied, on average, to only 380 patents per year ${ }^{301}$ and the PTO received only 1,659 requests for inter partes reexamination from November 1999 to June 2012. ${ }^{302}$

The pre-AIA regime of post-issuance review has been substantially modified with the introduction of multiple new procedures designed to minimize litigation costs and increase certainty. The new procedures took effect on September 16, 2012, one year from the date of enactment of the AIA. Ex parte reexamination procedures remain virtually unchanged, despite their various defects, ${ }^{303}$ but their importance has diminished compared to the new post-issuance patent review proceedings (post-grant review and supplemental examination) described below. In addition, inter

298. Rogers, supra note 289 , at 350 ("Patent reexams are limited in scope by SNQ's implicating only $\S \S 102$ and 103 , when much of patent claim invalidity argued during litigation involves $\S \S 112$ and 102 that are based on unprinted, prior art.").

299. See Report to Congress on Inter Partes Reexamination, U.S. Patent \& OFFICE (2004), available

http://www.uspto.gov/web/offices/dcom/olia/reports/reexam_report.htm; Kushan, supra note 283, at 394; Carrier, supra note 296, at 114 ("[I]nter partes reexamination is burdened by two strong estoppel provisions. One prevents a requester from challenging the validity of any fact determined in the examination. The other prohibits a requester from later asserting the invalidity of a patent on any ground that it raised or could have raised.") (internal quotations omitted); Rogers, supra note 289, at 322 (noting that ex parte reexaminations are not subject to these strong estoppel effects).

300. See Masur, supra note 292, at 481 (noting that inter partes reexamination "imposes such disadvantages on third-party challengers that it is almost never used").

301. Carrier, supra note 296, at 113.

302. USPTO Inter Partes Reexamination Filing Data, supra note 287, at 1 . The use of inter partes reexamination accelerated in recent years. During the fiscal years 2000 to 2004, the PTO received a total of 53 inter partes reexamination filings. During the fiscal years 2008 to 2012, the PTO received more than 1,350 such filings. Id.

303. See Stefan Blum, Note, Ex Parte Reexamination: A Wolf in Sheep's Clothing, 73 Онio State L.J. 395, 433 (2012) (noting that ex parte reexamination is "essentially intact" under the AIA). The major change was a substantial increase in fees in September 2012. Crouch, supra note 291 (noting a substantial increase in fees in September 2012). Fees were later reduced in March 2013. The fee for requesting an ex parte reexamination decreased from $\$ 17,750$ to $\$ 12,000$. Fees for supplemental examinations, petitioning for IPR, and petitioning for PGR also declined, as did standard fees for micro-entities. See Dennis Crouch, USPTO Fee Changes on March 19, PAtently-O (Mar. 18, 2013; 9:15 AM), http:/www.patentlyo.com/patent/2013/03/uspto-fee-change-on-march-19.html. 
partes reexamination has been substantially altered and re-designated as "inter partes review." PGR and IPR have become the primary vehicles for litigating patentability at the PTO. Each of the foregoing proceedings is examined below.

\section{Post-Grant Review}

Under the AIA's new first-to-file rules, post-grant review can be requested by any person who is not the owner of the patent no later than nine months following the grant of a patent or re-issuance of a patent issued from applications filed after March 16, 2013. ${ }^{304}$ Given that in the 2012 fiscal year it took an average of 32.4 months for a patent application to issue as a patent or be abandoned, ${ }^{305}$ PGR might not be commonly used before 2016 or 2017.

A petitioner may request to cancel as unpatentable one or more claims of a patent on any ground for invalidity under 35 U.S.C. $\S 282$, any requirement of 35 U.S.C. $\S 112$ (except for failure to disclose the best mode), and any requirement of 35 U.S.C. $\S 251$. PGR thus permits attacks based on, inter alia, invalidating prior art, prior public use, lack of enablement, lack of written description, lack of utility, lack of obviousness, lack of novelty, or prior sale or offer for sale. ${ }^{306}$ This is a considerably broader array of grounds than is available to challenge patents in reexaminations.

Formerly, a party seeking inter partes reexamination was required to show that cited prior art raised a SNQ of patentability. Under the AIA, a petition for PGR may be granted if (1) the information therein, if unrebutted, makes it "more likely than not that at least one of the claims challenged in the petition is unpatentable," $" 307$ or (2) "the petition raises a novel or unsettled legal questions that is important to other patents or applications." ${ }^{, 308}$ It is unclear what constitutes such a question and whether petitioner must establish that at least one claim is unpatentable if such a question exists.

304. 35 U.S.C. $§ 321$ (a), (c) (2011). For more than 200 years the United States gave priority of right to those who were first in time to an invention. The AIA changed that tradition and replaced it with a general rule under which patent rights are awarded to the first inventor to file a patent application. See 35 U.S.C. $§ 100$ (2011) (defining the first inventor to file rule).

305. United States Patent and Trademark Office, Performance and Accountability Report FY 2012, supra note 76, at 14 (showing patent application average pendency to be 32.4 months).

306. Robert Greene Sterne, et al., America Invents Act: The 5 New Post-Issuance Procedures, 13 SEDONA Conf. L.J. 27, 32 (2012) [hereinafter 5 Procedures].

307. 35 U.S.C. $\$ 324$ (a) (2012).

308. 35 U.S.C. $§ 324(b)(2012)$. 
On its face, the new PGR standard is higher than the SNQ previously required for initiating an inter partes reexamination. But once initiated, the preponderance of evidence standard will be used to determine the patentability of claims, as it is in ex parte reexaminations. Accordingly, a petitioner seeking PGR will ultimately confront the same burden to prove that a claim is invalid as petitioners previously did in inter partes reexaminations.

A party may seek PGR (or IPR) or instead opt to sue in district court, but neither PTO proceeding may be instituted by a party or a party's real party in interest if that entity previously contested the validity of a claim of the patent in civil litigation. ${ }^{309}$ The PTO's decision whether to open a PGR is final and non-appealable. ${ }^{310}$ PGRs are adjudicated by three-judge panels of the new Patent Trial and Appeal Board (PTAB), ${ }^{311}$ which replaced the back-logged Board of Patent Appeals and Interferences (BPAI) within the PTO. ${ }^{312}$

Pre-AIA, inter partes reexamination had no discovery component, ${ }^{313}$ but PGR and IPR both permit limited discovery with poorly defined boundaries. Discovery in both PGR and IPR is narrower than discovery in

309. 35 U.S.C. $\S \S 315(a)(1), 325(a)(1)$ (2012). The filing of a counterclaim of invalidity in an action commenced by the patent owner does not constitute a civil action challenging the validity of a claim of a patent. $\S \S 315(a)(3), 325(\mathrm{a})(3)(2012)$.

310. Versata Dev. Corp. v. Rea, No. 1:13-cv-328 (GBL/IDD), 2013 WL 4014649, at *5 (E.D. Va. Aug. 7, 2013) (holding that court lacks subject matter jurisdiction because "the AIA expressly precludes judicial review of the decision to institute post-grant review").

311. 35 U.S.C. § 326(c) (2012); Matthew A. Smith, Inter Partes Revocation PROCEEDINGS $\S 14: 1$ (2012) (stating that a panel of three judges generally conducts a postgrant review). The PTAB's membership includes the Director, the Deputy Director, the Commissioner for Patents, the Commissioner for Trademarks, and administrative law judges. Karen A. Lorang, The Unintended Consequences of Post-Grant Review of Patents, 17 UCLA J.L. \& TECH. 1, 8 (2013).

312. 35 U.S.C. $§ 6(a)$ (2012) (“Any reference in any Federal law, executive order, rule, regulation, or delegation of authority, or any document of or pertaining to the Board of Patent Appeals and Interferences is deemed to refer to the Patent Trial and Appeal Board."); see also Dennis Crouch \& Jason Rantanen, Pending Appeals Not Impacted by BPAI -> PTAB Transformation, PATENTly-O (Sept. 16, 2012, 10:34 AM), http://www.patentlyo.com/patent/2012/09/pending-appeals-not-impacted-by-bpai-ptabtransformation.html (explaining that the name change from BPAI to PTAB would have no effect on the pending ex parte appeals before the Board). The BPAI's backlog of pending appeals increased from 1,357 in 2006 to 22,356 in 2011, an increase of more than 1,600 percent in five years. Rogers, supra note 289, at 351. By May 2013, the backlog exceeded 25,000 cases, even following a significant reduction. Dennis Crouch, Slow and Steady: PTAB Continuing to Address Backlog of Ex Parte Appeals, PAtently-O (May 1, 2013, 2:16 PM), http://www.patentlyo.com/patent/2013/05/slow-and-steady-ptab-continuing-toaddress-backlog-of-ex-parte-appeals.html.

313. See Abbott Labs. v. Cordis Corp., 710 F.3d 1318, 1327 (Fed. Cir. 2013) (affirming grant of motion to quash two subpoenas duces tecum for use in inter partes reexamination proceeding). 
federal district court, and discovery in IPR is narrower than it is in PGR. In post-grant review the parties may take discovery directly related to factual assertions advanced by either party ${ }^{314}$ whereas discovery in inter partes review is limited to depositions of witnesses who submitted affidavits or declarations and what is "otherwise necessary in the interest of justice." 315 PGR's broader discovery is appropriate, because the grounds for challenging a patent are more substantial in PGR than in IPR.

The new materiality standard established in Therasense may affect inequitable conduct allegations that a patent challenger considers asserting in an infringement action filed after an inter partes review (or IPR). For example, a PGR that invalidates "some but not all claims may be used to prove the materiality of a reference that was not cited in the original prosecution of a patent." 316 How often will this occur? Pre-AIA approximately one percent of patents were litigated ${ }^{317}$ and litigation often proceeded concurrently with PTO proceedings. Approximately seventy percent of patents in inter partes reexamination and thirty-three percent of patents in ex parte reexaminations also were in district court litigation, ${ }^{318}$ even though the proceedings were designed to be an alternative to litigation. Post-grant review presents the potential to shift numerous patent validity disputes from the federal courts to the PTO, given the opportunity to challenge a patent based on any invalidity theory, a lower standard of proof, the absence of any presumption of validity, and the fact that PGR may be much quicker than litigation. ${ }^{319}$ Whereas the AIA provides for PGRs (and IPRs) to be decided by the PTAB within twelve months from

314. 35 U.S.C. $\S 326(a)(5)(2012)$.

315. 35 U.S.C. $§ 316(a)(5)$ (2012). The PTAB has outlined a five-factor analysis that it will use to determine whether to allow additional discovery that is otherwise necessary in the interest of justice. See Dennis Crouch, Discovery Process in Post-Grant Proceedings, PAtently-O (Mar. 22, 2013, 11:48 AM), http://www.patentlyo.com/patent/2013/03/abbottcordis-pgr.html. See also 5 Procedures, supra note 306, at 41 (predicting, on the basis of historical interference practice, that the "otherwise necessary" option "will provide little, if any, avenue to obtain discovery").

316. Eric S. Walter \& Colette R. Verkuil, Patent Litigation Strategy: The Impact of the America Invents Act and the New Post-Grant Patent Procedures 6, MORRISON \& FoERSTER (2012), available at http://www.mofo.com/files/Uploads/Images/120307-Patent-LitigationStrategy.pdf.

317. Rantanen, Petherbridge \& Kesan, supra note 292, at 229. The number of patent actions commenced in federal district court reached 4,015 in 2011 - the highest number of annual filings ever recorded. PricewaterhouseCoopers, supra note 274, at 6 .

318. Linck, StONER, BARRETT \& SPIEGEL, supra note 293, at ix; Rogers, supra note 289, at 319 (noting that reexamination "has become an integral part of patent litigation strategy").

319. Justin A. Hendrix \& Robert F. Shaffer, Post Grant ProceEdings of the AIA Provide New Opportunities and Require Reconsideration of Old Patent Litigation STRATEGIES, Finnegan (June 15, 2012), available at $\mathrm{http}: / / \mathrm{www}$. finnegan.com/resources/articles/articlesdetail.aspx?news=598696f7-7eba-4fcb83b8-2369caa91dd3. 
institution of the proceedings (with the possibility of an additional sixmonth extension for good cause), ${ }^{320}$ the median time to trial in patent litigation remained steady at approximately two and a half years during the period from 2005 to 2011 . $^{321}$

Notwithstanding the foregoing, PGR is unlikely to be widely used, given the high cost of analyzing potential threats from thousands of patents. ${ }^{322}$ More likely, such review will be used in targeted fashion by companies focusing on emerging patent portfolios of strategic competitors. The nine-month window for seeking PGR also is likely to restrict the use of review as a non-litigation option, particularly for small- and medium-size businesses that lack the infrastructure necessary to monitor the issuance of competitors' patents. ${ }^{323}$

Perhaps the greatest disincentive to frequent use of post-grant review may be provided by its robust estoppel effect. The AIA requires the PTAB to issue a final written decision concerning the patentability of any patent claim challenged by the petitioner and any new claim added during PGR. ${ }^{324}$ Issuance by the PTAB triggers PGR's estoppel effect. If the decision is adverse to the petitioner, she is estopped from asserting invalidity before the PTO, International Trade Commission (ITC), or a federal court on any basis that was raised or reasonably could have been raised during the PGR. ${ }^{325}$ This differs considerably from the estoppel effect attaching to inter partes reexamination pre-AIA, which followed exhaustion of all appeals. Under the AIA, estoppel is attainable within twelve to eighteen months, in contrast with the approximately six years an appeal from an inter partes reexamination took to make its way through the PTO and

320. 35 U.S.C. $§ 326(a)(11)$, (c) (2012).

321. PricewaterhouseCoopers, supra note 206 , at 21 ; cf. Barney, supra note 26 , at *1 (predicting that AIA will result in "many more post-grant review challenges" in the PTO, but not necessarily a corresponding reduction in federal court litigation).

322. One projection of the average cost for PGR/IPR is $\$ 150,000$ to $\$ 300,000$ per party, "an order of magnitude less expensive than district court litigation." Matthew Cutler, Inter Partes Review and Post Grant Review are Game-Changers, IP LAw360 (Jan. 8, 2013), http://www.law360.com/articles/402322/why-inter-partes-and-post-grant-review-are-gamechangers; see also Megan M. La Belle, Patent Law as Public Law, 20 Geo. Mason L. Rev. 41, 57 (2012) (observing that inter partes reexamination costs substantially less than litigation); Rogers, supra note 289, at 355-56 (comparing predicted cost of IPR of $\$ 600,000$ to average cost of patent litigation of $\$ 6$ million per side).

323. See Hung H. Bui, An Overview of Patent Reform Act of 2011: Navigating the Leahy-Smith America Invents Act Including Effective Dates for Patent Reform, 93 J. PAT. \& TRADEMARK OFF. SOC'Y 441 (2011) (predicting that nine-month window will operate to limit use of PGR); Rantanen, Petherbridge \& Kesan, supra note 292, at 229 (arguing that for many small businesses and inventors, PGR "will operate more as a patent system-use tax, adding to the cost and complexity of obtaining an enforceable patent").

324. 35 U.S.C. $\S 328($ a) (2012).

325. 35 U.S.C. $\S 325(\mathrm{e})(2012)$. 
obtain a final opinion from the Federal Circuit. ${ }^{326}$ No doubt the speed with which estoppel takes effect will weigh heavily in the decision calculus concerning pursuit of PGR (or IPR). Adverse final PGR decisions estop petitioners, real parties in interest, or privies of the petitioner. They do not estop patent owners. This uneven application of estoppel is likely to dissuade prospective petitioners from regarding PGR as an attractive substitute for litigation. ${ }^{327}$

The AIA's robust estoppel effect also is present in IPR, but it could be particularly acute in PGR $^{328}$ where the grounds on which a petitioner may assert invalidity are unrestricted and there is no exemption from the scope of estoppel for newly discovered prior art. The lack of restriction offers significant opportunities to find that a basis for invalidity either was raised or reasonably could have been raised, thereby triggering the estoppel effect. This broad estoppel is likely to operate as a significant deterrent to the use of PGR by petitioners, except where the facts supporting invalidity are very strong.

As discussed below, the AIA's new supplemental examination procedure offers a major opportunity for patentees to prevent prior art references or other information from being used as the basis for subsequent allegations of inequitable conduct. This opportunity makes it likely that patent owners will seek supplemental examination of patents for prior art references cited in PGR or IPR, in order to immunize the patents from exposure to later charges of inequitable conduct if that information was used by the PTAB to invalidate. ${ }^{329}$

\section{Inter Partes Review}

The AIA's new inter partes reviews will permit few if any occasions to bolster or assert an inequitable conduct defense. IPR replaced inter partes reexamination on September 16, 2012, and applies to patents issued before, on or after that date-not merely those patents issued on or after November 29, 1999, as in the case of inter partes reexamination. There are other important differences between the two procedures. IPR allows the

326. Phillippe Signore, Steve Kunin \& Jonathan Parthum, Practice Implications of the Leahy-Smith America Invents Act, Westlaw J. EXPERT Comment Series, PATENTS in the 21st Century: The LeAhy-Smith America Invents ACt, 2012, at 28, 30, available at http://www.mofo.com/files/Uploads/Images/120206-Patents-21st-Century.pdf.

327. Sandip H. Patel, A Lop-Sided Estoppel in Post-Grant Review, LAw360 (Dec. 21, 2011, 12:28 PM), http://www.marshallip.com/media/pnc/2/media.502.pdf.

328. See Kayla Fossen, Note, The Post-Grant Problem: America Invents Falling Short, 14 MinN. J.L. SCI. \& TECH. 573, 593 (2013) (noting that robust estoppel effect of PGR may reduce overall use of the procedure); Walters \& Verkuil, supra note 316, at 4 ("Post-grant review carries a greater potential likelihood for estoppel than inter partes review.").

329. Walters \& Verkuil, supra note 316 , at 6. 
patentee to respond to the petition and explain why the review should not proceed, whereas in inter partes reexamination a response by the patentee was only allowed after the examiner instituted reexamination. Further, unlike inter partes reexamination, a petition for IPR may not be filed until nine months after the grant of a patent or issuance of a reissue patent ${ }^{330}$ or after termination of a PGR, whichever happens later. ${ }^{331}$ Inter partes review thus is available to requesters seeking to challenge the validity of a patent after the nine-month window for filing post-grant review has closed.

Inter partes review introduces a new standard to commence review that replaces the former SNQ standard. This standard also differs from the new test applicable in PGRs. The presentation of a novel or unsettled legal question is not a valid ground for granting IPR. Rather, the petitioner must show that the information presented in her petition, together with any response from the patentee, establishes "that there is a reasonable likelihood that the petitioner would prevail with respect to at least [one] of the claims challenged in the petition." 332 Another difference between IPR and PGR is that in the former, a patent may only be challenged on the ground that it lacks novelty in violation of 35 U.S.C. $\S 102$ or that it was obvious in violation of 35 U.S.C. $\S 103$, and only on the basis of prior art patents and printed publications. ${ }^{333}$

As in the case of PGR, the PTO's decision whether to open an inter partes review is final and non-appealable. It is unclear whether the petitioner can request that the Director review the PTO's denial of an IPR, and what recourse, if any, the petitioner has if IPR is granted for some, but not all, claims. IPRs are adjudicated by three-judge panels of the new PTAB ${ }^{334}$ As noted, discovery is available, ${ }^{335}$ but it tends to significantly favor patentees, insofar as they generally receive priority and are able to conduct discovery even before they file their responses to petitioners. This serves to makes the strong estoppel provisions of IPR even stronger. Estoppel is triggered by the final written decision of the PTAB and applies to all issues that were raised or reasonably could have been raised in the

330. Reissue provides a second opportunity for a patentee to have the PTO examine a patent on all the same statutory bases that were or might have been employed during the original examination. A reissue application is the vehicle for conducting this second examination. Linck, StONER, BARRETT \& SPIEGEL, supra note 293, at 22.

331. 35 U.S.C. $\S 311$ (c) (2012).

332. 35 U.S.C. $\S 314$ (a) (2012). It is unclear what it means to "prevail" in this context. It could mean that at least one claim is rejected. Alternatively, it could refer to cancellation or substantial amendment.

333. 35 U.S.C. $§ 311$ (b) (2012).

334. Eldora L. Ellison, Patent Reform is on the Immediate Horizon - New Options for Challenging Patents Before the USPTO (Sterne Kessler Goldstein Fox P.L.L.C.), June 27, 2011, at 1 , available at $\mathrm{skgf.com} / \mathrm{media} / \mathrm{pnc} / 3 /$ media.1373.pdf.

335. 35 U.S.C. $\S 316(a)(5)(2012)$. 
review. ${ }^{336}$ Given the availability of discovery, it would not be difficult to successfully maintain that a broad range of issues could have been raised. ${ }^{337}$ As with PGR, the robust estoppel effect applies to other proceedings in the PTO, as well as civil actions and proceedings before the ITC. ${ }^{338}$

PTAB decisions are appealable directly to the Federal Circuit. The losing party in an IPR cannot return "to the PTO for any proceeding, including ex parte reexamination and PGR." ${ }^{339}$ Prior to enactment of the AIA, litigation did not preclude inter partes reexamination and, absent a discretionary stay, the proceedings could advance in tandem. Inter partes reexaminations were used by parties to create a record to support their stances in ongoing litigation. For example, litigants would use the procedure to develop a defense to a claim of inequitable conduct. ${ }^{340}$ The situation is different now. It may be more difficult to obtain IPR than it was to obtain inter partes reexamination pre-AIA, because the standard for obtaining review has changed. The prior SNQ standard was met in ninetyfour percent of inter partes reexamination requests. ${ }^{341}$ The new standard may yield a lower percentage.

There are at least two other limiting factors. First, IPR is unavailable where there is litigation concerning the patent and either more than one year has passed since the petitioner (or someone in privity with the petitioner) was served with the patent infringement complaint $^{342}$ or the petitioner filed a civil action challenging the validity of a claim of the patent before filing the petition for IPR. ${ }^{343}$ Second, the PTO Director has the authority to impose a limit on the number of IPRs that may be instituted during each of the first four years of implementation. This limit had been projected at $270 .^{344}$ Inter partes reexamination was rare pre-AIA. IPR may be even rarer, ${ }^{345}$ thus further restricting the option to litigants to bolster

336. 35 U.S.C. $\S 315(\mathrm{e})(2012)$.

337. Andrei Iancu, Ben Haber \& Elizabeth Iglesias, Challenging Validity of Issued Patents before the PTO: Inter Partes Reexam Now or Inter Partes Review Later?, 94 J. PAT. \& TRADEMARK OfF. SOC'y 148, 155 (2012) [hereinafter Now or Later].

338. 35 U.S.C. $\$ 315(\mathrm{e})(2012)$.

339. Now or Later, supra note 337, at 153.

340. Ben M. Davidson, Reexamining Reexaminations, 34 L.A. LAw. 26, 29 (2012).

341. USPTO Inter Partes Reexamination Filing Data, supra note 279, at 1.

342. 35 U.S.C. $\S 315$ (b) (2012).

343. 35 U.S.C. § 315(a)(1) (2012); Iancu \& Haber, supra note 289, at 476.

344. 5 Procedures, supra note 306 , at 37.

345. IPR ultimately may be more rare, but early statistics do not necessarily support such a projection. Between September 2012 and December 2013 the PTO received 766 filings under the AIA's new IPR provisions. See AIA Statistics: Inter Partes Review, U.S. PATENT \& TRADEMARK OFFICE, http://www.uspto.gov/aia_implementation/statistics.jsp (last visited Feb. 22, 2014). In contrast, the PTO received 1,659 inter partes reexamination filings during the period November 1999 to June 2012. See text accompaning supra note 303. 
their inequitable conduct defenses.

\section{Supplemental Examination}

The AIA's new supplemental examination provisions are very likely to restrict the inequitable conduct defense as well. Indeed, supplemental examination has been described as "the AIA's cure for the 'plague' of inequitable conduct." request supplemental examination of a patent" any time after its issuance "to consider, reconsider or correct information believed to be relevant to the patent." ${ }^{347}$ The new provisions, set forth in amended 35 U.S.C. $§ 257$ (Section 12 of the AIA), took effect in September 2012, ${ }^{348}$ apply to any patent regardless of issue date, and provide for reexamination if the Director concludes that the reference presented in the request presents a SNQ of patentability. ${ }^{349}$

If he so concludes, then reexamination proceeds primarily according to the current ex parte reexamination rules, with some differences. The most important difference is that the current restriction limiting ex parte reexaminations to consideration of prior art patents and printed publications is inapplicable in supplemental examinations and "information" is not limited or defined by the AIA. Supplemental examinations can be based on

346. See Bhattacharyya \& McGurk, supra note 84 , at 624 .

347. 35 U.S.C. $\$ 257$ (a) (2012).

348. The PTO has projected that all of the approximately 110 requests it received annually from patent owners for ex parte reexaminations pre-AIA will be filed as requests for supplemental examinations post-AIA, and that it will receive approximately 1,430 requests for supplemental examinations annually. See Changes to Implement the Supplemental Examination Provisions of the Leahy-Smith America Invents Act and to Revise Reexamination Fees; Final Rule, 77 Fed. Reg. 48828, 48847-48 (Aug. 14, 2012). These projections have been disputed. See Dennis Crouch \& Jason Rantanen, Supplemental Examination Final Rules, PAtently-O (Aug. 13, 2012, 3:48 PM), http://www.patentlyo.com/patent/2012/08/supplemental-examination-final-rules.html (predicting that the actual number would be "much, much smaller" than the PTO's projection of 1,430). During the period from September 2012 to December 2013, the PTO received 59 requests for supplemental examination. See AIA Statistics: Supplemental Examination, U.S. PATENT AND TRADEMARK OfFICE, http://www.uspto.gov/aia_implementation/statistics.jsp (last visited Feb. 2, 2014). Sixteen of the requests were publicly available as of August 2013 and of those sixteen, fourteen had been considered by the PTO. The PTO ordered reexaminations and/or found an SNQ in eleven of the fourteen (approximately seventy-eight percent). Patent claims were rejected in eight of the eleven, following ex parte reexamination. Eugene T. Perez \& Utsav Gupta, Some Early Statistics for Supplemental Examination, LAw360 (Aug. 13, 2013, 11:32 AM), http://www.law360.com/articles/462658/some-early-statistics-for-supplemental-

examination. Cost may be one primary factor that is constraining the use of supplemental examination. See Bhattacharyya \& McGurk, supra note 84, at 638 (noting that supplemental examination "is expected to be very expensive").

349. 35 U.S.C. $§ 257$ (a) (2011). 
any information believed relevant to the patent. For this reason, a patent owner may take advantage of supplemental examinations to alert the PTO to prior art patents and printed publications, as well as non-print prior art and non-prior art information held by the Federal Circuit to be material in inequitable conduct cases prior to Therasense. ${ }^{350}$ This is a much broader scope of information than the "patent and printed publications" limitation of ex parte reexamination. A second important difference is that the patent owner, who filed the request for supplemental examination, is barred from submitting a statement. ${ }^{351}$

Supplemental examination is not available if allegations of inequitable conduct have been "pled with particularity in a civil action." 352 If defendant alleges in court that certain conduct constitutes inequitable conduct, the patentee loses the ability to cure the defect through supplemental examination. But this exception is likely to have very limited application, because evidence of inequitable conduct is frequently unavailable until discovery occurs ${ }^{353}$ and typically the timing of the onset of litigation is within the patentee's control. In most cases, patentees can be expected to exercise such control by filing an absolving request for supplemental examination prior to taking any action that might trigger a declaratory judgment action. ${ }^{354}$ Moreover, the requirement that inequitable conduct be pled with particularity in order to trigger the exception likely entails compliance with Exergen. For all of the reasons described supra, it is very difficult to satisfy Exergen's pleading standard.

In the absence of the rare exception, supplemental examination will permit a patentee to effectively inoculate a patent against all but the most egregious forms of inequitable conduct by resubmitting the patent for reexamination based on corrected information. Once that corrected information is considered, the patent cannot later be held unenforceable on

350. Lisa A. Dolak, America Invents the Supplemental Examination, but Retains the Duty of Candor: Questions and Implications, 6 AKron InTELl. Prop. J. 147, 151 (2012).

351. 35 U.S.C. $\$ 257$ (b) (2012).

352. 35 U.S.C. $\S 257($ c)(2)(A) (2012).

353. See Formax Inc. v. Alkar-Rapidpak-MP Equip. Inc., No. 11-C-0298, 2013 WL 2368824, at *6 (E.D. Wis. May 29, 2013) ("Allegations of inequitable conduct are often based on information uniquely within the possession of the patentee, and often cannot be brought until after significant discovery has been completed.").

354. See Tokic, supra note 263, at 262 ("Thus, it appears unlikely the exception will preclude patent holders from strategically manipulating the supplemental examination rules to escape inequitable conduct claims."). There is a second exception, set forth in 35 U.S.C. $\S 257(\mathrm{c})(2)(\mathrm{B})$ (2012), but it too will be rarely used. It relates to patent infringement actions under Section 281 of the Patent Act or actions in the ITC for unfair competition or importation under Section 337(a) of the Tariff Act of 1930 (19 U.S.C. § 1337(a)). Under the second exception, the effect of supplemental examination will not apply unless the examination and any reexamination resulting from it are finished prior to the date on which the action is brought. 35 U.S.C. $§ 257$ (c)(2)(B) (2012). 
the basis of conduct relating to such information. This is true even if a reexamination is not conducted. ${ }^{355}$ The legislative history of the AIA indicates that supplemental examination can serve to prevent a patent from subsequently being held invalid, ${ }^{356}$ and the PTO has publicly stated that "[a] patent owner may use supplemental examination to forestall a subsequent inequitable conduct challenge to the enforceability of the patent during litigation. ${ }^{357}$ This signaling effect alone may be sufficient to ensure that inoculation occurs.

The proceeding is available only to patent owners, ${ }^{358}$ who will be able to cure intentional failures to disclose prior art that would otherwise be grounds for a finding of inequitable conduct. The AIA requires patentees to request and conclude supplemental examination before attempting enforcement. ${ }^{359}$ Where that occurs, examinations can be used as free passes by patent owners who deceive the PTO. As such, supplemental examinations create a patent amnesty program. ${ }^{360}$ Amnesty is created not merely for issued patents. It also is created for any other patent that, if it had been examined in light of information relevant to the patentability of the claimed invention reasonably available during the initial examination, might not have been issued or might have been issued in a much narrower form. ${ }^{361}$ This differs considerably from pre-AIA post-grant procedures, wherein the submission of information for consideration by the PTO was an effective admission of its materiality. ${ }^{362}$ The Federal Circuit has held that the submission of information during reexamination does not bar the subsequent assertion of an inequitable conduct defense based on such information, and in fact can provide a basis for the defense. ${ }^{363}$

The overarching effect is that supplemental examination destroys any incentive for patentees to provide honest disclosure to the PTO during the patent application process, and thereby significantly undermines one of the primary goals of the U.S. patent system. Post-grant review is unlikely to

355. LinCK, StONER, BARRETT \& SPIEgEL, supra note 293, at 120.

356. Joe Matal, A Guide to the Legislative History of the America Invents Act: Part II of II, 21 FED. CIR. B.J. 539, 539 (2012).

357. Press Release, U.S. Patent and Trademark Office, USPTO Publishes Final Rules for Supplemental Examination and Inventor's Oath or Declaration (Aug. 13, 2012), available at $\mathrm{http}: / / \mathrm{www} . u s p t o . g o v / n e w s / \mathrm{pr} / 2012 / 12-51 . j \mathrm{sp}$.

358. 35 U.S.C. $\$ 257$ (a) (2011).

359. 35 U.S.C. $\$ 257$ (2011).

360. Rantanen, Petherbridge \& Kesan, supra note 292, at 244 (concluding that supplemental examinations provide the opportunity "to immunize all but the most egregious misconduct before a competitor ever has an opportunity to learn of it").

361. Rantanen \& Petherbridge, supra note 51, at 26-27.

362. 5 Procedures, supra note 306 , at 58.

363. See, e.g., Therasense, Inc. v. Becton, Dickinson \& Co., 649 F.3d 1276, 1288 (Fed. Cir. 2011) (en banc) (noting that "inequitable conduct cannot be cured by... reexamination"). 
negate the powerful impact of supplemental examinations, because such examinations are likely to touch a much broader body of patents. ${ }^{364}$

Likewise, while the potential impact of the amnesty is blunted because the Director must make a confidential referral to the U.S. Attorney General for possible prosecution if the Director becomes aware during the course of a supplemental examination or related reexamination that material fraud may have been committed on the PTO, ${ }^{365}$ this reduction in impact is liable to be extremely limited. The AIA does not identify the distinctions between inequitable conduct (which can be corrected) and fraud (which apparently cannot). ${ }^{366}$ Subsequent to Therasense, the two are closer than they have ever been. The Director had the power to encourage prosecution of those who engage in material misconduct long before the AIA was enacted, but that power was almost never exercised. ${ }^{367}$ A 2013 review concluded that the two most recent prosecutions for dishonesty before the PTO occurred in 1976 and $1934{ }^{368}$ There is no reason to assume the situation will change following enactment. Even if the PTO does make a referral to the Attorney General it still must conclude the supplemental examination. ${ }^{369}$ And the "chronically underfunded"370 PTO itself has shown virtually no interest in regulating patent attorneys who engage in misconduct. Indeed, it stopped enforcement of the inequitable conduct doctrine in $1988 .^{371}$

Finally, insofar as the statute of limitations for the criminal law most likely applicable (18 U.S.C. $\S 1001$, which establishes liability for false statements in matters involving the U.S government) ${ }^{372}$ is five years, ${ }^{373}$

364. Rantanen, Petherbridge \& Kesan, supra note 292, at 245.

365. 35 U.S.C. $\$ 257$ (e) (2012).

366. Frederick Frei \& Sean Wooden, Inequitable Conduct Claims One Year After Therasense, Managing Intell. Prop.: The Global IP Resource (Andrews Kurth, D.C.), July $\quad 2012, \quad$ at $5, \quad$ available at http://www.google.com/url?sa=t\&rct=j\&q=\&esrc=s\&source=web\&cd=1\&ved=0CC4QFjA A\&url $=$ http $\% 3 \mathrm{~A} \% 2 \mathrm{~F} \% 2 \mathrm{Fwww}$. andrewskurth.com\%2Fmedia\%2Farticle $\% 2 \mathrm{~F} 1620$ Managin g\%2520IP\%2520Article.pdf\&ei=63yNUsXpKO3D4AOVvYGwAg\&usg=AFQjCNETTfva Xgmk_1EFDBAp97gMKuc77g\&sig2=-

BaRSyqQK6AbU7aMeZ2IBQ\&bvm=bv.56988011,d.dmg\&cad=rja.

367. Rantanen \& Petherbridge, supra note 51, at 26.

368. Chiang, supra note 3, at 1297.

369. Matal, supra note 356, at 539.

370. Rochelle Cooper Dreyfuss, In Search of Institutional Identity: The Federal Circuit Comes of Age, 23 Berkeley TeCH. L.J. 787, 813 (2008). However, the PTO's budget did approximately double to $\$ 3$ billion, from fiscal year 2006 to fiscal year 2014. See Dennis Crouch \& Jason Rantanen, USPTO's Budget to Rise Significantly, PATENTLY-O (Jan. 17, 2014), http://patentlyo.com/patent/2014/01/usptos-budget-to-rise-significantly.html.

371. See Chiang, supra note 3 , at 1271 (explaining that the PTO has not conducted inequitable conduct investigations for more than twenty years).

372. 18 U.S.C. $§ 1001$ (a)(1) (2012) makes it a crime to knowingly and willfully falsify, conceal or cover up by any trick, scheme or device a material fact in any matter within the 
measured from the date each element of the crime has occurred, ${ }^{374}$ prosecution for most material misconduct would be time-barred by the time a patent is scrutinized in a supplemental examination or ex parte reexamination. In fiscal year 2012, it took an average of 32.4 months for a patent application to issue as a patent or be abandoned, even longer than the 32.2 months it took in fiscal year 2009. ${ }^{375}$ Given this almost three-year lag, which shows no major signs of improvement, ${ }^{376}$ it is likely that supplemental examinations will not be requested, and fraud will not be discovered, until after five years has elapsed. ${ }^{377}$

Supplemental examinations are overtly designed to reduce patentees' exposure to inequitable conduct claims, ${ }^{378}$ unnecessarily replicate the effect of Therasense, ${ }^{379}$ and thereby threaten to make the inequitable conduct defense a historic relic. ${ }^{380}$ The overall outcome is likely to be more fraud before the PTO, ${ }^{381}$ accompanied by a net increase in the cost of

jurisdiction of the executive, legislative, or judicial branch of the federal government.

373. The applicable five-year statute of limitations is set forth in 18 U.S.C. $\S 3282$ (a) (2012). See, e.g., United States v. Smith, 740 F.2d 734, 736 (9th Cir. 1984).

374. See United States v. Smith, 740 F.2d 734, 736 (9th Cir. 1984) (outlining when the statute of limitations begins to run). Accord United States v. Lutz, 154 F.3d 581, 586 (6th Cir. 1998).

375. U.S. Patent and Trademark Office, Performance and Accountability Report Fiscal Year 2012, supra note 76, at 14.

376. The fiscal year 2012 average total pendency of 32.2 months did reflect a decline from the 33.7 months in fiscal year 2011 and also bettered the PTO's fiscal year 2012 target of 34.7 months. See id.

377. Chiang, supra note 3, at 1297 ("Because it is unlikely that fraud on the PTO will be discovered in five years - and patentees can virtually ensure this by waiting six years before doing anything with their patent-there is little credible deterrence from criminal prosecution."); White, supra note 3, at 731.

378. Sarah Tran, Patent Powers, 25 Harv. J.L. \& TeCH. 595, 638 (2012). But cf. Angie M. Hankins, Iuliana Tanase \& Reiko Manabe, Is Inequitable Conduct Still a Viable Defense?, LAw 360 (Nov. 22, 2011), http://www.law360.com/articles/285249/isinequitable-conduct-still-a-viable-defense ("[S]upplemental examination appears to be directed toward close calls or error, rather than permitting the curing of intentional and egregious misconduct before the PTO.").

379. See Kelly, supra note 220 at $* 3$ (observing that the incentive to use supplemental examination "seems greatly diminished" after Therasense); Kevin B. Laurence \& Matthew C. Phillips, Supplemental Examination and the Proposed Rules, Intellectual Property TODAY 7, 8 (Mar. 2012) ("Therasense significantly diminished the need for supplemental examination ....").

380. See Peter E. Strand, Disarming an 'Atomic Bomb': Federal Circuit Clips Wires for Inequitable Conduct, 24 No. 8 InTELl. Prop. \& TECH. L.J. 20, 22 (2012) (concluding that supplemental examinations may make the inequitable conduct defense "a dinosaur").

381. See Maurice Ross, A Year of Dramatic Change in Intellectual Property Law: Who are the Winners and Losers?, ASPATORE, 2013 WL 571327, at *8 (Jan. 2013) ("This new 'get out of jail free' law, together with recent Federal Circuit jurisprudence making it almost impossible to prove inequitable conduct, conveys exactly the wrong message and provides perverse incentives for cheating and fraud."); accord Priscilla G. Taylor, Bringing Equity Back to the Inequitable Conduct Doctrine?, 27 Berkeley TeCH. L.J. 349, 372 (2012) 
competition, higher barriers to market entry, decreased innovation, lowerquality patents, and a decline in the economic competitiveness of the U.S. ${ }^{382}$

In summary, the AIA's new provisions for supplemental examination and post-grant review, together with its modification of inter partes review, will substantially constrict the inequitable conduct defense.

\section{B. Best Mode}

Similar to the AIA's post-issuance review provisions, the AIA's new best mode provision also will operate to constrain the use of the inequitable conduct defense. At least since the 1800s U.S. patent law has required an inventor to disclose the best mode associated with application of the principle of her invention. ${ }^{383}$ This best mode requirement has applied to all classes of inventions beginning with the 1952 Patent Act, ${ }^{384}$ which in 35 U.S.C. $\S 112$ requires the inventor seeking a patent to disclose the "best mode... of carrying out her invention." 385 The requirement does not require actual disclosure of the best mode, but instead only adequate disclosure to enable someone of ordinary skill in the art to practice the best mode without undue experimentation. ${ }^{386}$ Under the 1952 Patent Act the failure to disclose best mode during patent prosecution could result in rejection by the patent examiner. ${ }^{387}$

Determining compliance with the best mode requirement is a twoprong fact-based inquiry. First, it must be determined whether, at the time

(concluding that supplemental examinations could lead to increased incidence of inequitable conduct before the PTO).

382. See, e.g., Rantanen \& Petherbridge, supra note 51, at 31 (noting that AIA "presents a very real risk of increasing the number of low-quality patents").

383. The Patent Act of 1836 required a patent applicant to explain the principle of her invention and the "several modes" associated with application of that principle, as contemplated by the inventor. Patent Act of 1836, ch. 357, § 6, 5 Stat. 117 (repealed 1870). The Patent Act of 1870 required a patent applicant to explain the principle of her invention and the best mode associated with application of that principle, as contemplated by the inventor, but this requirement applied only to machine patents. Patent Act of July 8, 1870, ch. 230, § 26, 16 Stat. 198, amended by Patent Act of 1952, Pub. L. No. 593, 66 Stat. 792 (1952).

384. Patent Act of 1952, ch. 950, § 112, 66 Stat. 792 (1952) (codified as amended at 35 U.S.C. $\S 112(2006))$.

385. 35 U.S.C. $\S 112$ (2006).

386. Joy MM Delaware, Inc. v. Cincinnati Mine Mach., Co., 497 F. App'x 970 (Fed. Cir. 2012); Ajinomoto Co. v. Int'l Trade Comm'n, 597 F.3d 1267, 1273 (Fed. Cir. 2010). Routine details apparent to someone of ordinary skill in the art need not be disclosed to satisfy the best mode requirement. In re Cyclobenzaprine Hydrochloride Extended-Release Capsule Patent Litig., 676 F.3d 1063, 1086 (Fed. Cir. 2012).

387. Ryan G. Vacca, Patent Reform and Best Mode: A Signal to the Patent Office or a Step Toward Elimination?, 75 AlB. L. REV. 279, 293 (2012). 
the patent application was filed, the inventor possessed a best mode for practicing the invention. This is a subjective inquiry ${ }^{388}$ that focuses on the inventor's state of mind at the time of filing. Second, if the inventor did possess a best mode, it must be determined whether the written description disclosed the mode such that a person skilled in the art could practice it. This is an objective inquiry that focuses on the scope of the claimed invention and the level of skill in the art. ${ }^{389}$

There is some confusion as to whether invalidation based on a best mode violation requires that the inventor knew of and intentionally concealed a better mode than was disclosed. The Federal Circuit has not always been clear about this issue. In some cases it seems to have required concealment ${ }^{390}$ but in other cases it has stated that intent to conceal is not an element. ${ }^{391}$ In still other cases, the court has explained that it uses the term "concealment" as a shorthand way of inquiring about the adequacy of the disclosure. ${ }^{392}$ Section 112 does not on its face impose a concealment requirement. ${ }^{393}$

Failure to disclose the best mode has furnished grounds for rejecting patent applications in the PTO and, more commonly, for declaring the

388. Anvik Corp. v. Nikon Precision, Inc., 519 F. App'x 1019, 1024 (Fed. Cir. 2013).

389. Pfizer, Inc. v. Teva Pharms. USA, Inc., 518 F.3d 1353, 1364 (Fed. Cir. 2008); Responsive Innovations, LLC v. Holtzbrinck Publishers, LLC, 911 F. Supp. 2d 526, 537 (N.D. Ohio 2012).

390. See Ateliers de la Haute-Garonne v. Broetje Automation USA Inc., 717 F.3d 1351, 1357 (Fed. Cir. 2013) ("Violation requires intentional concealment; innocent or inadvertent failure of disclosure does not of itself invalidate the patent."); Wellman, Inc. v. Eastman Chem. Co., 642 F.3d 1355, 1365 (Fed. Cir. 2011) ("'Invalidation based on a best mode violation requires that the inventor knew of and intentionally concealed a better mode than was disclosed."') (citing High Concrete Structures, Inc. v. New Enter. Stone \& Lime Co., 377 F.3d 1379, 1384 (Fed. Cir. 2004)).

391. See In re Cyclobenzaprine Hydrochloride Extended-Release Capsule Patent Litig., 676 F.3d 1063, 1085 (Fed. Cir. 2012) (noting that an examination of intent to conceal is inconsistent with an objective inquiry). See also Multimedia Patent Trust v. Apple Inc., No. 10-CV-2618-H (KSDC), 2012 WL 6863471, at*9 (S.D. Cal. Nov. 9, 2012) ("The Court agrees with the Cyclobenzaprine Hydrochloride opinion. Therefore, Apple and LG do not need to present evidence showing that the inventors intentionally concealed the better mode.").

392. See In re Cyclobenzaprine Hydrochloride Extended-Release Capsule Patent Litig., 676 F.3d at 1085-86 (discussing use of the term "concealment" to describe a test of the adequacy of disclosure); U.S. Gypsum Co. v. Nat'l Gypsum Co., 74 F.3d 1209, 1215-16 (Fed. Cir. 1996) ("A best mode violation may occur if the disclosure of the best mode is so objectively inadequate as to effectively conceal the best mode from the public.") (emphasis in original); see also Jason Rantanen, Best Mode: Only Mostly Dead, PATENTLY-O (May 27, 2013; 11:53 AM), http:/www.patentlyo.com/patent/2013/05/best-mode-only-mostlydead.html (predicting that the Federal Circuit split "will likely remain forever unresolved").

393. See 35 U.S.C. $\S 112$ (2012) (illustrating that section 112 does not mention a concealment requirement). 
patents invalid or unenforceable in subsequent litigation. ${ }^{394}$ Invalidity for failure to satisfy the best mode requirement must be proven by clear and convincing evidence, ${ }^{395}$ and compliance with the requirement is both a question of fact ${ }^{396}$ and often highly factual. ${ }^{397}$ The Federal Circuit reviews findings of best mode disclosure violations for clear error. ${ }^{398}$

The best mode requirement has several related justifications. The first justification is to ensure that the public is placed on a level playing field with the patentee upon expiration of the patent. ${ }^{399}$ The second is to compensate the public for the cost of the monopoly created by a patent. ${ }^{400}$ A third is to realize basic notions of fairness. ${ }^{401}$

Best mode has endured in the U.S. despite being subject to criticism on several grounds. First, best mode has failed to level the field because it is subjective - only the best mode contemplated by the inventor must be

394. Lee Petherbridge \& Jason Rantanen, The Pseudo-Elimination of Best Mode: Worst Possible Choice?, 59 UCLA L. Rev. Discourse 170, 171 (2012) (noting that pre-AIA, courts were required to declare patents invalid where applicants knew of best mode and failed to disclose it); Brian J. Love \& Christopher B. Seaman, Best Mode Trade Secrets, 15 YALE J.L. \& TECH. 1, 7 (2012) (noting that "the primary means of enforcing best mode was in litigation").

395. In re Cyclobenzaprine Hydrochloride Extended-Release Capsule Patent Litig., 676 F.3d at 1087; AllVoice Computing PLC v. Nuance Commc'ns, Inc., 504 F.3d 1236, 1240 (Fed. Cir. 2007).

396. Bayer AG v. Schein Pharms., Inc., 301 F.3d 1306, 1312 (Fed. Cir. 2002).

397. See Anvik Corp. v. Nikon Precision, Inc., 519 F. App'x 1019, 1021 (Fed. Cir. 2013) ("The question whether the best mode requirement has been satisfied is highly factual.").

398. In re Cyclobenzaprine Hydrochloride Extended-Release Capsule Patent Litig., 676 F.3d at 1084; Zygo Corp. v. Wyko Corp., 79 F.3d 1563, 1566-67 (Fed. Cir. 1996).

399. Christianson v. Colt Indus. Operating Corp., 870 F.2d 1292, 1302 n.8 (7th Cir. 1989) (" $[T]$ he best mode requirement is intended to allow the public to compete fairly with the patentee following the expiration of the patents."); see also Joy MM Del., Inc. v. Cincinnati Mine Mach., Co., 497 F. App'x 970, 974 n.2 (Fed. Cir. 2012) (“At its heart, the best mode requirement is concerned with preventing inventors from concealing the best mode of their inventions while being rewarded with the right to exclude others from making or using it."); Chisum, supra note 33, at 280 ("The purpose of the best mode requirement is to prevent inventors from obtaining patent protection while concealing from the public the preferred embodiments of their inventions.").

400. Eli Lilly \& Co. v. Barr Labs., Inc., 251 F.3d 955, 963 (Fed. Cir. 2001) ("The best mode requirement creates a statutory bargained-for-exchange by which a patentee obtains the right to exclude others from practicing the claimed invention for a certain time period, and the public receives knowledge of the preferred embodiments for practicing the claimed invention."); Matthew H. Solomson, Patently Confusing: The Federal Circuit's Inconsistent Treatment of Claim Scope as a Limit on the Best Mode Disclosure Requirement, 45 IDEA 383, 384 (2005) ("The purpose of the statutory disclosure requirements, in general, and the best mode requirement, in particular, is to compensate the public for the cost of the monopoly conferred on a patentee."); $c f$. Petherbridge \& Rantanen, supra note 274, at 126 (describing the policy purpose of the best mode requirement as "something of an enigma").

401. Wesley D. Markham, Is Best Mode the Worst?: Dueling Arguments, Empirical Analysis, and Recommendations for Reform, 51 IDEA 129, 131 (2011). 
disclosed, even if the best mode, in an objective sense, is not revealed to the public. ${ }^{402}$ Second, best mode also fails to meet its goal because the rapid pace of technological change may negate the best mode before the patent term ends. Third, best mode increases litigation $\operatorname{costs}^{403}$ while providing modest benefits, and, because the rule is virtually unique to the U.S., ${ }^{404}$ it places at a disadvantage foreign applicants who apply for patents in their home countries and then must amend their U.S. applications to comply with the best mode requirement. ${ }^{405}$ Finally, it has been argued that the courts have applied the best mode requirement inconsistently. ${ }^{406}$

Most of the foregoing points can be rebutted. First, while best mode is subjective, the inventor's subjective intent may be proven by inference from objective evidence, such as performance data for various embodiments of the invention. ${ }^{407}$ Second, there is little or no evidence definitively linking best mode to an increase in patent litigation costs, ${ }^{408}$ and the AIA's abolition of failure to disclose best mode as a basis for finding invalidity or unenforceability will result in only modest savings and may even increase costs, because the volume of discovery is not expected to decline. ${ }^{409}$ Third, the notion that best mode is unique to the U.S. is untrue. According to one survey, by 2005 at least twenty-four countries required best mode disclosure, ${ }^{410}$ and the global trend has reflected

402. Vacca, supra note 387, at 288.

403. Before the AIA was enacted, members of Congress and testifying witnesses repeatedly complained about the high cost associated with best mode determinations. See Matal, supra note 356, at 582.

404. Chisum, supra note 33, at 279; Lisa Larrimore Ouellette, Do Patents Disclose Useful Information?, 25 HARV. J.L. \& TECH. 531, 553 (2012) (noting that best mode is not imposed in Europe).

405. NAT'L ReSEARCh COUNCIL OF THE NAT'L ACADS., A PATENT SySTEM FOR THE $21^{\text {ST }}$ CENTURY 121 (Stephen A. Merrill et al. eds., 2004), available at http://www.nap.edu/catalog.php?record_id=10976 (noting that only the U.S. has a best mode requirement and characterizing it as an "unusual additional requirement"); Petherbridge \& Rantanen, supra note 394, at 171 ("Perhaps the most common argument for eliminating best mode was that it disadvantaged foreign inventors.").

406. See Solomson, supra note 400, at 420 ("[T]he Federal Circuit's best mode decisions cannot be explained by a consistent set of principles."); Steven B. Walmsley, Best Mode: A Plea to Repair or Sacrifice this Broken Requirement of United States Patent Law, 9 Mich. Telecomm. \& TeCh. L. Rev. 125, 153 (2002) (criticizing best mode on basis that courts have used seven different standards for assessing the disclosure required to comply with the obligation).

407. Love \& Seaman, supra note 394, at 19.

408. Markham, supra note 401, at 142-43 (noting that the hypothesized incremental cost of best mode cannot be disentangled from other variables that affect the same cost).

409. Love \& Seaman, supra note 394, at 16.

410. Andrew R. Shores, Comment, Changes to the Best Mode Requirement in the Leahy-Smith America Invents Act: Why Congress Got it Right, 34 CAMPBELL L. ReV. 733, 745 (2012). 
adoption. $^{411}$

The AIA did not substantively change the best mode requirement (except insofar as the requirement now encompasses the best mode contemplated by the inventor or joint inventor). Amended Section 35 U.S.C. $§ 112$ still requires patent applicants to disclose a best mode if they know of one. ${ }^{412}$ However, courts will no longer enforce this requirement, insofar as the AIA amended 35 U.S.C. $§ 282$ to eliminate failure to disclose the best mode as a ground for asserting invalidity of the patent, unenforceability, or cancellation of any or all claims in a patent. ${ }^{413}$ Thus, under the AIA, patent applicants must disclose the best mode to receive a patent, but if a patent is obtained despite a failure to so disclose, no challenge to the patent rights can be made based on such a failure. The prohibition on invalidating a patent claim for failure to disclose best mode encompasses ex parte reexamination and post-grant review. The foregoing mixed outcome appears to represent a compromise between critics of best mode who wanted to abolish it entirely and proponents who wanted to preserve it in some fashion. ${ }^{414}$

Prior to adoption of the AIA intentional best mode violations could be deemed inequitable conduct. ${ }^{415}$ It is not entirely clear whether inequitable conduct based on intentional concealment of the best mode remains a viable defense in civil litigation post-AIA. Nothing in the statute explicitly excludes such a defense. The AIA only excludes failure to disclose the best mode as a direct basis for invalidity or unenforceability, but defendants generally did not assert such a failure in pre-AIA litigation.

411. Dale L. Carlson, Katarzyna Przychodzen \& Petra Scamborova, Patent Linchpin for the 21st Century? - Best Mode Revisited, 45 IDEA 267, 283-85 (2005). The authors refer to the assertion that only the U.S. imposes a best mode requirement as a "common misconception." Id. at 281.

412. 35 U.S.C. $\$ 112($ a), amended by Leahy-Smith America Invents Act $\S 4$.

413. 35 U.S.C. $\$ 282(b)(3)(A)(2012)$. This amendment was not given retroactive effect for cases that were filed before the America Invents Act was enacted. Anvik Corp. v. Nikon Precision, Inc., 519 F. App'x 1019, 1021 (Fed. Cir. 2013).

414. Love \& Seaman, supra note 394, at 8. Cf. Matal, supra note 356, at 584 ("The legislative history provides no explanation for Congress's failure to simply repeal the bestmode requirement entirely. Nor is one apparent.").

415. See Consol. Aluminum Corp. v. Foseco Int'l Ltd., 910 F.2d 804, 808 (Fed. Cir. 1990) (holding that failure to disclose best mode is inherently material and "reaches the minimum level of materiality necessary for a finding of inequitable conduct"); Chisum, supra note 33, at 281 ("If a best mode violation is intentional, it can be deemed inequitable conduct, resulting in unenforceability of the entire patent and other adverse consequences...."); see also Responsive Innovations, LLC v. Holtzbrinck Publishers, LLC, 911 F. Supp. 2d 526, 544 (N.D. Ohio 2012) (noting that the failure to disclose best mode will not constitute inequitable conduct in every case); Old Town Canoe Co. v. Confluence Holdings Corp., 448 F.3d 1309, 1322 (Fed. Cir. 2006) (confirming that failure to disclose best mode is inherently material, but finding no intent to deceive PTO and therefore no inequitable conduct). 
Rather, they asserted inequitable conduct before the PTO as the direct basis for a finding of unenforceability. However, the foregoing distinction is unlikely to prevail, because the AIA does not distinguish between direct and indirect bases for validity and unenforceability. Congress, when it enacted the AIA, was aware that best mode violations were frequently styled as inequitable conduct claims, and this probably explains why the AIA excludes failure to disclose the best mode as a basis for both invalidity and unenforceability. ${ }^{416}$ The failure to disclose best mode almost certainly has been eliminated as a direct and indirect basis for asserting invalidity or unenforceability. ${ }^{417}$

Prior to enactment of the AIA, best mode was not a primary defense and it was rarely successful. ${ }^{418}$ Now it has been eliminated as a defense altogether. While the best mode requirement has been nominally retained, it has been rendered a virtual nullity in any proceeding in which the issue of compliance with the requirement might arise. ${ }^{419}$

It has been suggested that best mode retains some utility under the AIA, for a couple of reasons. First, even if evidence supporting the defense has become inadmissible at trial, a patent applicant's knowledge of a best mode may be reasonably calculated to lead to the discovery of admissible evidence relevant to a claim of inequitable conduct or unclean hands. ${ }^{420}$ Second, if discovery reveals an undisclosed best mode, the doctrine of

416. Vacca, supra note 387, at 293 \& n.108.

417. See Petherbridge \& Rantanen, supra note 274, at 126-27 (concluding that the AIA "has, as a practical matter, effectively eliminated the best mode requirement from patent law"). But cf. Harkins, supra note 69 , at *10 ("At least theoretically . . . if a defendant can show that the patent applicant intentionally withheld the best mode, that may constitute inequitable conduct. It remains to be seen how courts will handle that argument, since failing to disclose best mode is not a typical fraud on the USPTO."); Markham, supra note 401, at 156 ("In effect, eliminating best mode as a defense in patent litigation would fold any best mode related issues that arise into a court's general inequitable conduct analysis."); Jayson Singh Sohi, Comment, Changes to the Best Mode Requirement: Weakening Enforcement Undermines the Purpose of Patent Law and Exacerbates an Ethical Patent Trilemma, 17 INTELl. PROP. L. BuLl. 157, 168 (2013) (arguing that the only likely means of redress for post-AIA violations of the best mode requirement "will have to come in the form of an inequitable conduct inquiry").

418. See Bayer A.G. v. Schein Pharms., 301 F.3d 1306, 1316 (Fed. Cir. 2002) ("In the history of this court and our predecessor courts we have held claims invalid for failure to satisfy the best mode requirement on only seven occasions."); Kelly, supra note 220 at *3 ("[F]ew patents over the past twenty years [prior to 2012] have been invalidated on best mode grounds."); Markham, supra note 401, at 149-52 (concluding that (a) the best mode defense succeeded in district court only eighteen percent of the time during the period 20052009; (b) the Federal Circuit affirmed a district court's holding that there was a best mode violation only once during the period 2002-2009; and (c) the BPAI never affirmed in a published decision an examiner's best mode rejection during the period 1981-2009).

419. Robert A. Armitage, Understanding the America Invents Act and its Implications for Patenting, 40 AIPLA Q.J. 1, 87-93 (2012).

420. Love \& Seaman, supra note 394 , at 21. 
unclean hands may provide a remedy. ${ }^{421}$ As to the first point, however, the combination of Exergen, Therasense, and the AIA's new post-issuance proceedings has essentially eviscerated the inequitable conduct defense. As to the second point, the doctrine of unclean hands has never been an effective substitute for inequitable conduct for the reasons discussed supra. As noted, a party who is foreign to the alleged unclean conduct at the time of its occurrence generally cannot raise a claim of unclean hands. And whereas application of the inequitable conduct doctrine results in the unenforceability of the entire patent, the unclean hands defense merely allows courts to dismiss complaints filed by plaintiffs suing in bad faith.

The AIA's revision of best mode may create an incentive for inventors to actively conceal the best mode, ${ }^{422}$ as long as the risk of detection by the PTO is sufficiently low. In fact, the risk of detection by the PTO is virtually nonexistent, because the patent examiner will almost never have evidence sufficient to permit her to conclude that the inventor, at the time of filing the application, knew of a better mode of practicing the claimed invention. ${ }^{423}$ The PTO acknowledges this point in the Manual of Patent Examining Procedure. ${ }^{424}$

The effective elimination of best mode and its concomitant constriction of the inequitable conduct defense undermine the quid pro quo basis of patent law, which is that the patent applicant should play fair and square with the patent system. It is unfair if the applicant can receive from the public the right to exclude, while at the same time maintaining part of the invention as a trade secret by concealing from the public the preferred embodiment of the invention. ${ }^{425}$ Prior to the AIA, best mode also played a critical role in establishing the level of inventiveness necessary for a patent

421. Id.

422. John Villasenor, The Comprehensive Patent Reform of 2011: Navigating the Leahy-Smith America Invents Act, 184 Brookings Policy Brief 1, 4 (Sept. 2011), available

http://www.brookings.edu/ /media/research/files/papers/2011/9/patents\%20villasenor/09_p atents_villasenor.pdf.

423. Shores, supra note 411, at 738-39 (“[T] make enforcement of the best mode requirement during the examination virtually impossible.”); Vacca, supra note 387, at 294.

424. See Manual of Patent Examining Procedure $\S 2165.03$ (8th ed. 2001, $9^{\text {th }}$ rev. 2012), available at http://www.uspto.gov/web/offices/pac/mpep/mpep-2100.pdf ("The information that is necessary to form the basis for a rejection based on the failure to set forth the best mode is rarely accessible to the examiner ....").

425. Wahl Instruments, Inc. v. Acvious, Inc., 950 F.2d 1575, 1579 (Fed. Cir. 1991) ("The purpose of the best mode requirement is to restrain inventors from applying for a patent while at the same time concealing from the public preferred embodiments of their inventions which they have in fact conceived.") (emphasis in original); Amgen, Inc. v. Chugai Pharm. Co., Ltd., 927 F.2d 1200, 1209-10 (Fed. Cir. 1991) ("The best mode requirement thus is intended to ensure that a patent applicant plays 'fair and square' with the patent system. It is a requirement that the quid pro quo of the patent grant be satisfied."). 
to issue. As explained by Professors Petherbridge and Rantanen, "the best mode requirement cooperates with nonobviousness doctrine to protect the balance between incentive and access in the patent system." ${ }^{.426}$ The effective elimination of the best mode requirement terminates that protection. In short, the AIA limits the inequitable conduct defense at cross-purposes with fundamental objectives of the U.S. patent system.

\section{CONCLUSION}

Through a combination of judicial and political action, Therasense and the AIA have unduly narrowed the inequitable conduct defense. The Federal Circuit limited the defense explicitly and in substance by restricting its elements and establishing a more lenient disclosure obligation. Congress constrained the defense implicitly and largely through procedures. The AIA removed best mode violations as a basis for asserting inequitable conduct, and it established provisions for post-issuance review that provide patentees with a safe harbor from allegations of inequitable conduct. The restrictions imposed collectively by Therasense and the AIA will tend to undermine fundamental objectives of patent law. At a minimum, the undue contraction of the inequitable conduct defense will substantially reduce the incentive for patent applicants to make full and early disclosure to the overall detriment of the U.S. patent system. At the same time, Therasense will operate to substantially reduce the opportunity for parties to assert Walker Process antitrust claims. Overall, the cure has been worse than the plague.

426. Petherbridge \& Rantanen, supra note 274 , at 129. 